Instituto de Biociências

Universidade de São Paulo

MARCELO ARRUDA FIUZA DE TOLEDO

Orientação espacial e comportamento coletivo em formigas saúvas

Spatial orientation and collective behaviour

in leaf-cutting ants 

MARCELO ARRUDA FIUZA DE TOLEDO

\title{
Orientação espacial e comportamento coletivo em formigas saúvas
}

\section{Spatial Orientation And Collective Behaviour in Leaf-cutting} Ants

\author{
EXEMPLAR CORRIGIDO. Tese \\ apresentada ao Instituto de Biociências da \\ Universidade de São Paulo para obtenção \\ do título de Doutor em Ciências, na Área de \\ Fisiologia Geral.
}

Orientador: Prof. Dr. André Frazão Helene

O exemplar original encontra-se disponível no Instituto de Biociências da USP 
Ficha catalográfica elaborada pelo Serviço de Biblioteca do Instituto de Biociências da USP, com os dados fornecidos pelo autor no formulário: http://www.ib.usp.br/biblioteca/ficha-catalografica/ficha.php

de Toledo, Marcelo Arruda Fiuza

orientação espacial e comportamento coletivo em formigas saúvas / Marcelo Arruda Fiuza de Toledo; orientador André Frazão Helene Helene. -- São Paulo, 2018 .

$129 \mathrm{f} .+$ anexo

Tese (Doutorado) - Instituto de Biociências da Universidade de São Paulo, Departamento de Fisiologia.

1. Orientação espacial. 2. Comportamento coletivo. 3. Formigas. 4. Comportamento animal. I. Helene, André Frazão Helene, orient. II. Título.

Bibliotecária responsável pela estrutura da catalogação da publicação: Elisabete da Cruz Neves - CRB - 8/6228 
Nome: TOLEDO, Marcelo Arruda Fiuza de

Título: Orientação espacial e comportamento coletivo em formigas saúvas

Tese apresentada ao Instituto de Biociências da Universidade de São Paulo para obtenção do título de Doutor em Ciências, na Área de Fisiologia Geral.

Aprovado em :

Banca Examinadora:

Prof. (a) Dr (a)

Instituição:

Assinatura

Prof. (a) Dr (a)

Instituição:

Assinatura

Prof. (a) Dr (a)

Instituição:

Assinatura

Prof. (a) Dr (a)

Instituição:

Assinatura 

Aos meus pais, Edna e Jair, e à minha irmã Nathália 
"[O sábio é aquele que consegue] lamentar-se um pouco menos, esperar um pouco menos, mas amar um pouco mais"

André Comte-Sponville 


\section{Agradecimentos}

Agradeço ao meu orientador Prof. André Frazão Helene pela orientação e pela oportunidade de realização do projeto como aluno do laboratório. Aproveito para agradecer ao colega Pedro Ribeiro, a quem serei sempre grato pela minha formação científica.

Aos colegas de laboratório. Os de longa data: Dani, Wataru, Pedro (Toddy), Nathalia e os da próxima geração: Fernanda, Bruna, Mila Maria e Cleverson. Por todas as discussões, reuniões e valiosas trocas de ideias, pelas mãos extras de Bruna, Mila, Clev e Toddy. Aos colegas de curso de inverno, em especial ao Mateus, que sempre se empenharam em materializar essa que é das minhas mais estimadas atividades.

À meus pais e minha irmã, que me apoiaram sempre que precisei e sempre tiveram em mim a confiança que por vezes eu precisei buscar neles.

Um agradecimento especial à minha grande amiga Elisa Jordão, por todo apoio e suporte, inclusive nos momentos difíceis. Também especial à minha namorada Samantha Kuwada pela enorme paciência, por toda a ajuda e suporte, dos momentos críticos aos mais críticos e também pelos momentos de tranquilidade e paz. Seu suporte foi fundamental. Sem vocês eu não estaria aqui nesse momento.

Também aos meus m8's, meus irmãos mais novos: Pedro Pimenta, que nossa inestimável amizade se prolongue para muito além destes 16 anos, Benjamin Rudder cuja alegria de viver me contagia. É uma grande felicidade tê-los como amigos tão próximos.

Agradeço ao Cnpq pela bolsa concedida. 


\section{Sumário}

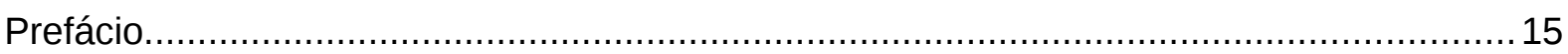

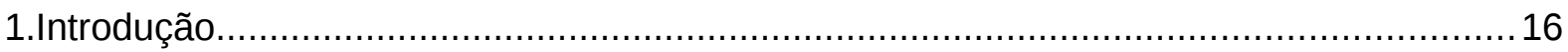

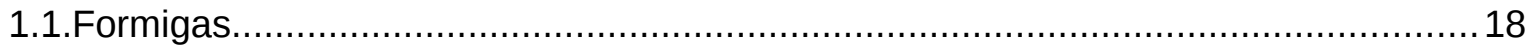

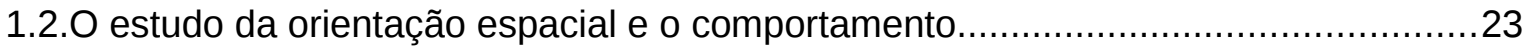

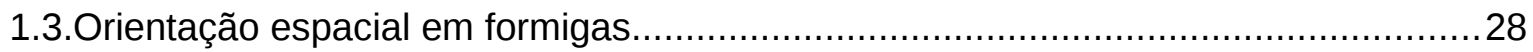

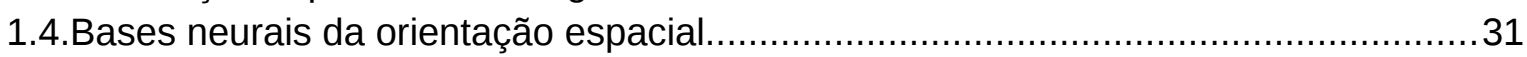

1.5.Comportamento coletivo e o uso do espaço em formigas........................................ 36

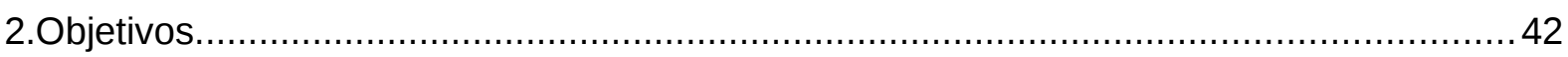

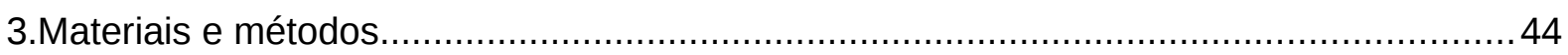

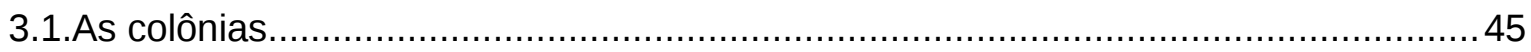

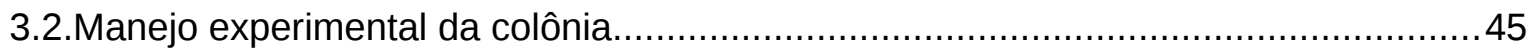

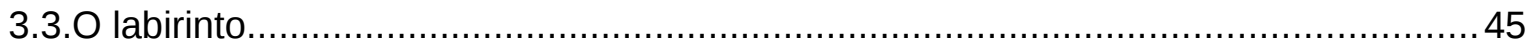

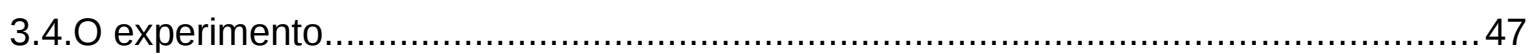

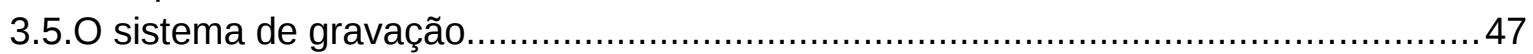

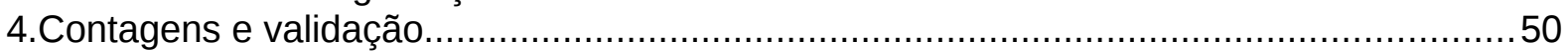

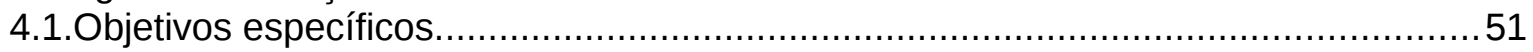

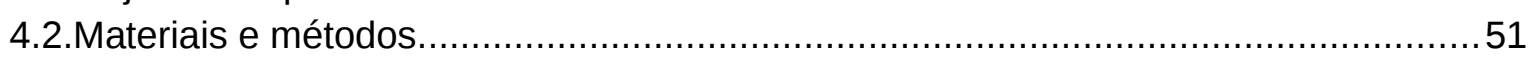

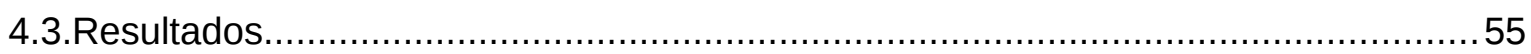

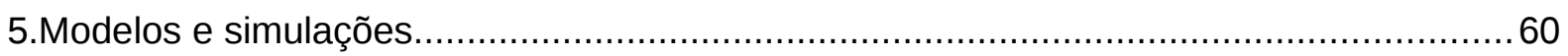

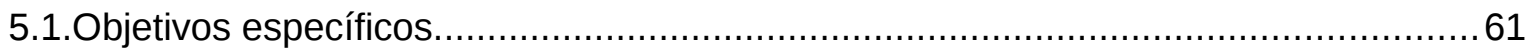

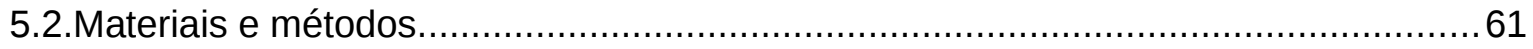

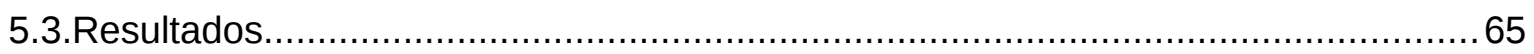

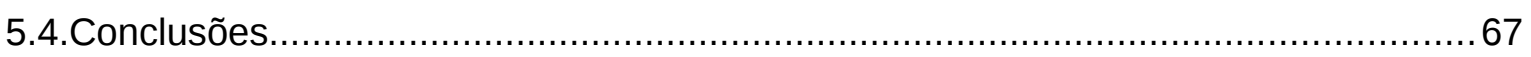

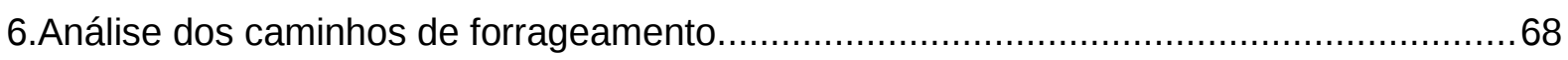

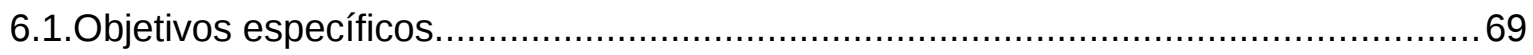

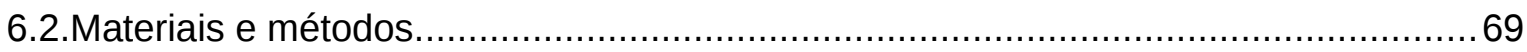

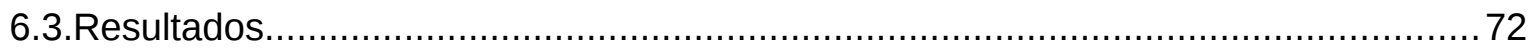

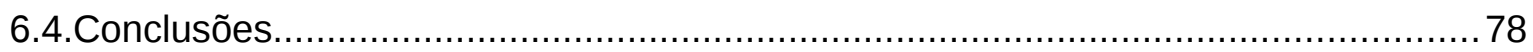

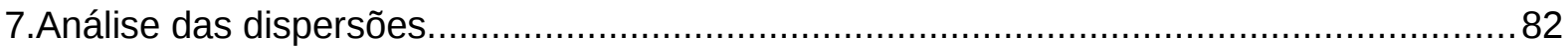

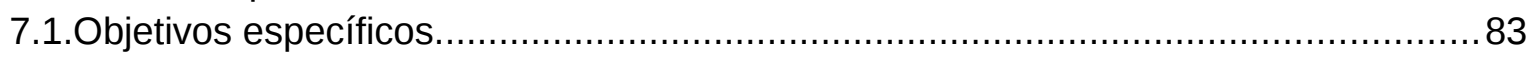

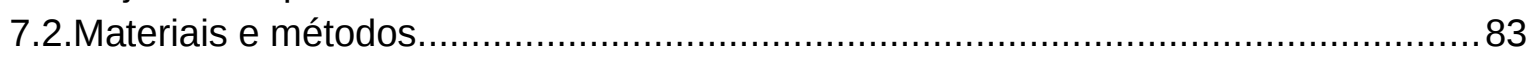

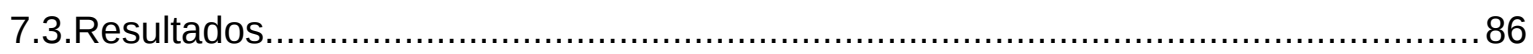

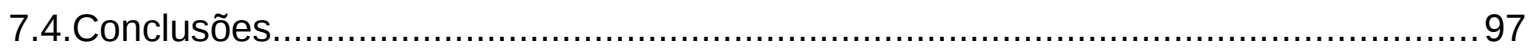

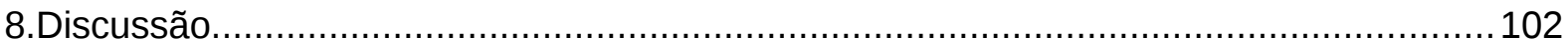

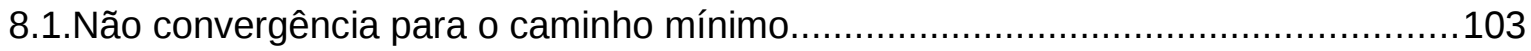

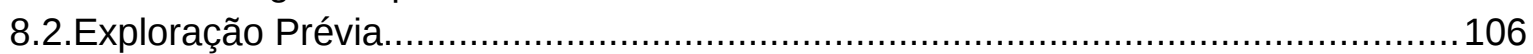

8.3.Comparação entre experimentos com folhas e controles........................................ 107

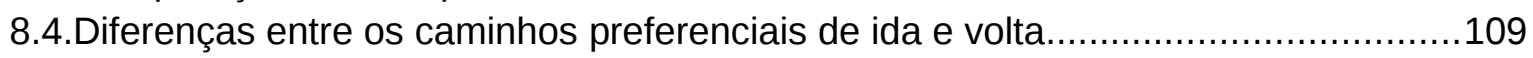

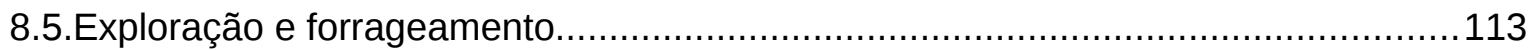

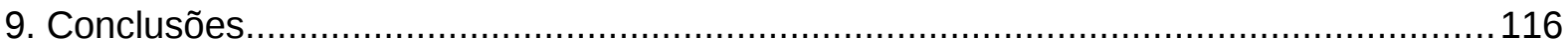

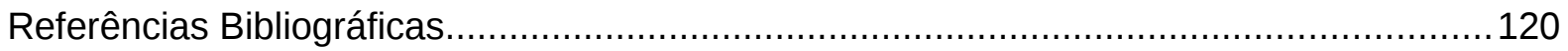

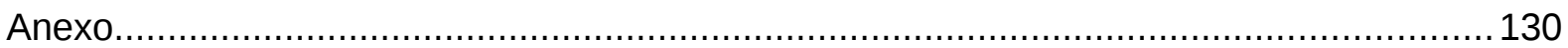




\section{Resumo}

A forma como as formigas se dispersam pelo espaço está relacionada tanto à processos coletivos de formação de trilhas preferenciais de forrageamento por meio de marcação feromonal quanto à fatores individuais como orientação por ângulos, distância e direção da colônia, o comportamento em bifurcações e memória individual. Entretanto a compreensão de como esses mecanismos se articulam na produção de uma resposta da colônia frente à uma tarefa espacial poucas vezes foi focado. Além disso, assim como no forrageamento, a forma como se dá a dispersão pelo espaço na exploração também é crítica. Sendo assim, a dispersão das formigas pelo espaço representa um ponto de balanço entre a exploração e o forrageamento, em que os fatores individuais e coletivos compõem conjuntamente uma resposta ao desafio espacial. No entanto, na medida em que o uso do espaço é frequentemente observado pelo ponto de vista da otimização do forrageamento, esse balanço é pouco explorado. O objetivo do trabalho foi avaliar como a dispersão espaço-temporal das formigas de uma colônia, produzida por mecanismos coletivos e individuais, reflete tanto o esforço exploratório quanto o de forrageamento. Para isso, foi criado um labirinto hexagonal duplo concêntrico e foram comparadas as dispersões das formigas em duas condições: com alimento numa posição específica, e em uma condição controle, em que o alimento era oferecido junto à colônia de forma que a dispersão fosse uma exploração desvinculada do forrageamento. Para a observação das formigas no labirinto, foram dispostas câmeras de vídeo sobre os corredores e foi desenvolvido um software de análise de vídeo para a contagem de formigas. Embora a dispersão decorrente do forrageamento e da exploração sejam indissociáveis, através da simulação computacional com modelos de referência em que predominam um dos casos foi possível avaliar o grau de contraste com dispersões observadas experimentalmente. Observamos que, de fato, os controles são mais próximos do modelo nulo de exploração e os experimentos com folhas do modelo de forrageamento. Embora o caminho preferencial observado tenha divergido do modelo, são mais próximos do modelo de forrageamento, mostrando a relação entre a forma da dispersão e os comportamentos subjacentes. Além disso, houve uma baixa convergência nos controles, ao passo que nos experimentos com folhas a formação de trilhas preferenciais apresentou graus variados de convergência. Na condição experimental a formação de trilhas preferenciais decorrente da marcação feromonal coletiva, em conjunto com o comportamento individual nas bifurcações assimétricas e o próprio desenho do labirinto favoreceram a separação entre as trilhas de ida e volta do alimento. Enquanto o caminho de ida permaneceu o mais provável dado o labirinto, o caminho de retorno foi otimizado, estabelencendo um caminho mínimo contralateral ao caminho de ida. Assim, a relação entre os mecanismos coletivos e individuais fornece um cenário apropriado para a análise do balanço entre 0 forrageamento e a exploração. 


\section{Abstract}

The means by which ants disperse is given by collective processes of preferential foraging trail formation by means of pheromone marking as well as by individual factors such as orientation by features' angles, colony distance and direction, choices at bifurcations and individual memory. However, how these mechanisms interact in producing a colony response given a spatial task has rarely been the focus of studies. In addition, as in the case of foraging, the spatial dispersal pattern for exploration is also critical. So, the ants dispersal in space represents a balance point between exploration and foraging, in which the individual and collective factors together compose a response to the spatial challenges. However, as the space occupation is frequently studied regarding foraging optimization, this balance is disregarded. The objective of this study is to understand how the spatiotemporal dispersal of ants in a maze, as produced by such collective and individual mechanisms, reflects both the exploratory and foraging efforts. With that aim, I created a double concentric hexagonal maze and compared the ants dispersal in two conditions: in the offering of food in a specific place, and in a control condition, food was given in the same place as the colony such that its dispersal is unrelated to foraging. In order to observe the ants behaviour, video cameras were set on top of each maze connection and a software was developed to count the passage of the ants. Although the dispersal due to foraging and from exploration are inseparable, using computer simulations of reference theoretical models of each case it was possible to contrast and measure the differences to the experimentally observed dispersals. We observed that indeed, the experimental group was closer to the foraging model while the control was closer to the null model of exploration. Although the observed preferential path was different from that of the foraging model, it was still closer, showing the relationship between the observed dispersal and the underlying behaviours. Moreover, there was a low convergence in the control group, while various degrees of convergence were observed in the experimental group. In the experimental group, the formation of preferential paths by means of collective pheremonal markings, together with individual preferences at asymmetric bifurcations and the design of the maze, favoured the separation between outbound and inbound paths. Whilst the outbound path remained the most probable given the geometry of the maze, the inbound path was optimised, establishing a minimal path on the opposite side of the outbound path. Thus, the relationship between the collective and individual mechanisms provide a more than appropriate scenario for the analysis of the balance between foraging and exploration. 


\title{
Lista de abreviaturas e siglas
}

\author{
ACO Ant Colony Optimization \\ [\#,\#, \# ] Sequência de trilhas numeradas \\ \#h Trilha numerada, sentido horário \\ \#ah Trilha numerada, sentido antihorário
}




\section{Prefácio}

O presente trabalho compreende a apresentação de um experimento e suas etapas de análise. Como foi realizado um único experimento, com um grupo experimental e outro controle, há uma seção de objetivos, materiais e métodos correspondente aos objetivos gerais do projeto e à descrição do experimento. Já as análises, por compreenderem o desenvolvimento de ferramentas computacionais de análise de imagens e simulações, além das análises dos resultados experimentais, foram divididas em seções. São quatros seções de análises, cada qual com seus objetivos específicos, materiais e métodos, resultados propriamente ditos e conclusões parciais. Ao final, para a análise conjunta dos resultados de cada etapa e discussão dos resultados obtidos face à literatura, há uma seção geral de discussão. 
1. Introdução 
Parando diante de uma trilha de formigas vemos apenas seus indivíduos se deslocando de um lado para outro, alguns com, outros sem folhas. Enxergar o que eles estão fazendo é uma tarefa mais difícil e depende de conhecer como eles marcam trilhas, cortam folhas ou defendem sua colônia. No entanto, entender a lógica que determina os processos presentes depende de mais do que o olhar. Depende de captar a estrutura final determinada pela forma como todos os indivíduos coletivamente estão sensíveis às inúmeras regras presentes. A proposta do presente trabalho é tratar de maneira detalhada sobre como as formigas estão coletivamente distribuídas em um espaço determinado, tentando buscar, a partir de análise destes padrões, a estrutura final que permita inferir as regras ali presentes.

Ao se observar uma colônia de formigas uma das primeiras coisas que vêm à mente é que os numerosos indivíduos se comportam de forma coletivamente integrada, funcionando como uma unidade. Logo após a observação do aspecto coletivo, é natural que se prossiga com a observação de indivíduos e suas respectivas tarefas. Enquanto algumas formigas transportam fragmentos de folhas, outras cortam folhas, outras se deslocam seguindo uma trilha ao encontro dessas e há ainda muitas outras, sobre as quais nada muito certo pode ser dito. E embora ainda persista a ideia do coletivo funcional organizado, ao observarmos os indivíduos, parece curioso que o numeroso comportamento errático corresponda de alguma forma à funcionalidade social da colônia.

A observação das formigas há muito tempo nos produz algum fascínio. Certamente o aspecto da sua socialidade nos chama a atenção. A busca por entender como é estabelecida a correspondência entre o que as formigas fazem e como a colônia sobrevive é sem dúvida um dos grandes desafios em se tentar compreender o comportamento desses animais. No presente trabalho propomos tratar como podemos entender o conjunto total de formigas explorando e forrageando num ambiente controlado, com múltiplas soluções possíveis. Tal esforço nos leva a tentar entender não apenas os fluxos que foram medidos, mas como se pode analisar estratégias de ocupação do espaço. Para isso, criamos uma ferramenta contagem de fluxo por imagem (ver adiante) e uma tarefa espacial num labirinto, possibilitando a descrição dos padrões observados e, além disso, comparamos os padrões obtidos com possíveis modelos presentes na literatura para tentar entender uma situação real envolvendo a avaliação de milhões de viagens individuais. Pretendemos com isso, 
tratar de como a organização social pode ser descrita a partir de evidências e modelos que são produto da integração de mecanismos individuais e coletivos.

\subsection{Formigas}

Formigas são insetos hymenopteros (filo: Arthropoda, classe: Insecta, ordem: Hymenoptera) e compõe a família Formicidae. Popularmente conhecidas e amplamente presentes ao redor do mundo, compartilham inúmeras características com abelhas e as vespas, também hymenopteros. Recentemente tem-se debatido a respeito de qual o grupo de vespas seria o mais próximo das formigas (JOHNSON et al., 2013). Essa discussão é importante para avaliar a evolução de caracteres comportamentais coletivos como o de coleta e transporte de alimento para o ninho, que as vespas Apoidea e Vespidae têm (ambos grupos eusociais), mas vespas Scolioidea (parasitóides) não apresentam. Também porque apesar de uma formiga ser individualmente muito menos capaz se comparada à capacidade da colônia, se sua base estrutural nervosa for herdada de vespas não sociais (como as parasitóides Scolioidea), seria razoável hipotetizar que ela ainda mantivesse um sistema nervoso capaz de produzir comportamentos sofisticados como encontrado nos indivíduos de espécies não sociais (FARRIS, 2005, 2016), inclusive habilidades de memória espacial (COLLETT; CHITTKA; COLLETT, 2013).

\subsubsection{Gênero Atta}

Formigas do gênero Atta, juntamente com as do gênero Acromyrmex, compõem a tribo Attini (WETTERER; SCHULTZ; MEIER, 1998) conhecidas como formigas cortadeiras por conta de dependerem do corte de vegetação fresca para o cultivo do fungo simbionte (WEBER, 1972). Nas formigas cortadeiras os numerosos indivíduos de uma colônia se dividem entre tarefas de corte e transporte de folha, o recorte em fragmentos menores, a limpeza (através de secreções salivares e anais) do material e a implantação dele no fungo simbionte, além de diversas outras tarefas não associadas à busca alimentar.

No Brasil, formigas do gênero Acromymex ocorrem na região centro-sul do país, com exceção do Rio Grande do Sul (DELLA LUCIA, 1993; MARICONI, 1970). Já o gênero Atta ocorre em toda a América do Sul, central e porção sul da américa do norte (México e metade sul dos Estados Unidos, principalmente). Atta sexdens, ocorre, especificamente, da Argentina até o Panamá (BORGMEIER, 1959; WILSON, 1980). 
No presente estudo foram utilizadas formigas saúvas-limão (Atta sexdens rubropilosa Forel, 1908) que, assim como todas as outras da tribo Attini, realizam o cultivo de fungo simbionte. A divisão de tarefas entre as formigas Atta sexdens foi observada e minuciosamente descrita por Wilson (1980). Primeiramente, foi realizada a observação e listagem das diferentes atividades. Posteriormente, a observação do tamanho das formigas que executavam cada tarefa. Através da execução de histogramas para cada tarefa (e sub tarefa), foi possível obter a distribuição de tamanhos de formigas que executam cada uma delas - o que o autor denominou curvas aloéticas. A partir da combinação de todas as curvas obtidas, ainda que houvesse grande sobreposição entre elas, pôde-se identificar quatro agrupamentos gerais de correspondências entre tamanhos de formigas e tarefas executadas por elas. Esses são: (i) jardineiras / enfermeira: moda 1,0mm - cuidado das hifas, implantação das folhas, cuidado com a prole; (ii) generalistas internas: moda 1,4mm processamento das folhas anterior à implantação, manejo de macroestrutura do fungo como túneis e câmaras, retirada de rejeitos, transporte de outras formigas, assistência à prole nas ecdises, assistência à rainha; (iii) Forrageadoras / escavadoras: 2,2mm - exploradoras, recrutam, cortam e transportam alimento para o ninho; escavam túneis e câmaras; (iv) soldados: quaisquer acima de 3,0mm, por simplificação, mas outras menores (entre o tamanho de forrageadoras e 3,0mm também podem exercer essa função), atuando no patrulhamento e defesa do ninho e das localidades adjacentes ocupadas. Dessa forma, se definiu o aloetismo (probabilidade de desempenho de uma tarefa dado o tamanho do indivíduo) e se pôde utilizar essas relações como base para se investigar o vínculo funcional entre polimorfismo e o polietismo e criar hipóteses evolutivas para o surgimento das diferenças e especializações.

\subsubsection{Eusocialidade}

As formigas são originalmente eussociais (SMITH et al.,2008). Isso implica (i) a divisão do trabalho reprodutivo de forma que haja tanto indivíduos capazes (rainhas e machos reprodutivos) quanto incapazes de reproduzirem-se (operárias), (ii) a sobreposição de gerações convivendo conjuntamente na mesma colônia, e (iii) o cuidado cooperativo com a prole alheia, em que as operárias cuidam da prole da rainha e não se reproduzem (WILSON, 1978) .

A condição em que as operárias abrem mão da produção de prole própria para o cuidado da prole alheia e dedicam todo o seu trabalho à colônia é vista como uma condição de altruísmo. Esse comportamento é evolutivamente viável devido à existência de parentesco entre os indivíduos envolvidos (HAMILTON, 1964a, 1964b). No caso, por se 
tratar de um sistema de determinação de gênero sexual haplodiplóide, o grau de semelhança genética esperada entre duas irmãs é de $75 \%$, o que facilita a seleção de parentesco. Comparativamente, em um sistema de determinação sexual diplóide, como, por exemplo, acontece em todos os mamíferos, irmãos de mesmos progenitores apresentam grau de semelhança genética esperada de 50\%. Assim, a melhor estratégia para passar mais genes comuns para a próxima geração é cuidar da prole da rainha, o que seria inclusive válido para o próprio gene altruísta, garantindo a estabilidade evolutiva dessa estratégia. Além de ter a vantagem de propiciar que a rainha tenha uma prole muito numerosa, cuja produção se estende por muito mais do que a vida das operárias, de forma que o ganho em termo de fitness inclusivo seja maior do que o custo de abrir mão da produção de prole própria, conforme expresso na regra de Hamilton (1964a, 1964b).

\subsubsection{Divisão do trabalho}

A divisão do trabalho ocorre em uma colônia tanto nas tarefas reprodutivas quanto não reprodutivas sendo um dos aspectos mais notórios das colônias de formigas e cumprindo um papel importante na produção de uma unidade funcional. A especialização de cada tarefa é possível na medida em que o trabalho total dê conta de todas as necessidades globais da colônia, reprodutivas ou não. Embora desde muito cedo essa visão já fosse presente (DARWIN, 1872), foi na expressão superorganismo (WHEELER, 1911) que o aspecto de unidade funcional ganhou destaque. Wheeler (1911), apontou não só a divisão da colônia entre parcelas reprodutiva e somática, mas além, categorizou a colônia como um indivíduo andrógino. A ideia do superorganismo ganhou maior importância também em função da sua interpretação face à concepção de manutenção da homeostase (CANNON, 1929), em que a divisão atuaria como fator de reforço da união funcional dos indivíduos para garantia da sobrevivência coletiva. Embora a visão do superorganismo careça da explicação do que ocorre do ponto de vista genético, como o altruísmo e o fitness inclusivo, a ideia tem sido mantida como uma metáfora profícua para a compreensão de que a divisão de tarefas atende à manutenção das condições de vida da colônia como um todo e se equipara à uma resposta de um organismo único frente ao meio.

Indivíduos desempenham mais frequentemente um subconjunto de tarefas dentro do conjunto total de tarefas realizadas pela colônia, e esse subconjunto varia entre os diferentes subgrupos de indivíduos. Dessa forma, alguns grupos de indivíduos se dedicam mais a determinadas tarefas enquanto outros grupos a outras. A forma precisa como essa divisão ocorre depende da espécie e corresponde à características próprias da biologia de cada uma, como por exemplo, o tipo de alimentação - se caçam ou são cortadeiras - e o 
tamanho da colônia. No caso das Atta, as tarefas não reprodutivas são tipicamente de forrageamento, e de manutenção, como cuidado com o fungo, cuidado das formas imaturas, retirada e organização do lixo e defesa (AUTUORI, 1950; OSTER; WILSON, 1978; WEBER, 1972). Ao se observar e listar o repertório de atividades (etograma) de diversos indivíduos é possível se estimar o número de grupos funcionalmente distintos dentro de uma colônia (WILSON, 1983) que se dedicam de forma mais ou menos específica na execução de conjuntos de tarefas. No caso das formigas saúvas, Wilson propôs a organização em sete subcastas, das quais quatro são morfologicamente distintas e as outras três diferem-se funcionalmente.

De forma geral, ao longo do tempo o foco da compreensão da divisão do trabalho (polietismo) se modificou (BESHERS; FEWELL, 2001), passando dos aspectos mais amplos como a idade dos indivíduos, a distribuição espacial e a demanda das tarefas no caso do modelo de forrageamento por trabalho (TOFTS; FRANKS, 1992), para aspectos individuais de decisão e resposta, como por exemplo no modelo de respostas individuais baseadas em limiares fixos e variáveis (BONABEAU, 1998; BONABEAU; THERAULAZ; DENEUBOURG, 1996). Atualmente, tem sido focado na divisão de trabalho não reprodutivo o seu aspecto flexível e dinâmico, sendo compreendida como uma rede descentralizada e dinâmica de interações, em que as tarefas são alocadas segundo uma relação de compromisso entre as demandas e a força de trabalho (GORDON, 2002, 1996, 2014). Dessa forma, a divisão é um produto das diferenças morfológicas entre as castas, a idade dos indivíduo e outros aspectos, operando segundo à ocupação espacial e as interações entre os indivíduos (MERSCH; CRESPI; KELLER, 2013).

Juntamente com a importância do aspecto dinâmico da divisão do trabalho, tem sido dada grande importância especialmente às interações locais entre os indivíduos. Por exemplo, a taxa de interação entre indivíduos forrageadores e indivíduos na entrada da colônia parece ser, em algum grau, determinante da quantidade desses indivíduos que irá forragear (PINTER-WOLLMAN et al., 2013; PLESS et al., 2015; UDIANI; PINTERWOLLMAN; KANG, 2015). Nesse sentido há uma importância não só na determinação pontual das tarefas a serem desempenhadas por um ou outro indivíduo num dado momento, mas exibem também um papel regulatório da quantidade de formigas desempenhando cada tarefa frente às condições momentâneas da colônia, cumprindo a 
função de um mecanismo de ajuste da resposta em termos de divisão do trabalho e alocação de tarefas diante das circunstâncias (PRABHAKAR; DEKTAR; GORDON, 2012).

\subsubsection{Trilhas}

Nas formigas cortadeiras, o deslocamento entre o ninho e a fonte de alimento, bem como o transporte do alimento para o ninho, é organizado tipicamente com a formação de trilhas de forrageamento. Uma trilha de forrageamento se inicia com uma formiga, que ao encontrar uma fonte de alimento, retorna ao ninho marcando o seu percurso de volta secretando feromônios sobre o substrato (WILSON, 1962). Ao chegar no ninho, essa formiga recruta mais indivíduos e estes seguem o percurso marcado por feromônios até a fonte de alimento. Essas formigas também voltam marcando a trilha, reforçando a intensidade da marcação feromonal e também recrutando mais formigas ao chegarem de volta ao ninho. Dessa forma, estabelece-se uma retroalimentação positiva entre a intensidade da marcação, que atua como estímulo para novas formigas, e a quantidade de formigas na trilha. No entanto, este feromônio é volátil. Assim, uma vez que, por exemplo, o alimento na fonte acabe, as formigas deixam de marcar o caminho de volta, e com o passar do tempo o feromônio depositado vai evaporando, reduzindo o estímulo para que novas formigas entrem na trilha. A volatilidade funciona como uma regulação negativa do mecanismo. Dessa forma, a trilha de forrageamento é não só o trânsito de indivíduos entre o ninho e a fonte de alimento, mas, através do mecanismo coletivo de retroalimentação de recrutamento em massa, é também uma forma de regulação da intensidade com que a atividade é desempenhada e de coordenação espacial do fluxo. Trilhas são não só o deslocamento coletivo entre a colônia e a fonte, mas um processo de decisão, regulação e ajuste das atividades de forrageamento e exploração coletiva.

A ideia de que as formigas marcam as trilhas com feromônios é bastante antiga (BONNET, 1779; MACGREGOR; THORPE, 1948), sendo a marcação em si identificada somente em 1959 (WILSON, 1959), e o mecanismo canônico descrito em 1962 (WILSON, 1962b). Mas esse mecanismo ainda tem consequências que só seriam descritas mais tarde (GOSS et al., 1989), que levam as colônias a estabelecer não só uma trilha funcional, mas a trilha mais curta entre o ninho e a fonte de alimento. Por exemplo, numa condição em que haja duas trilhas, uma longa e outra curta para mesma fonte de alimento, a formiga que retornar pelo caminho de menor distância levará menor tempo para fazê-lo. Dessa forma, a quantidade de feromônio que evapora durante o intervalo de tempo entre a formiga que marcou a trilha retornar ao ninho e uma seguinte que siga essa marcação é menor na trilha 
curta do que na longa. Consequentemente a trilha menor apresenta um estímulo mais intenso que a trilha maior e a probabilidade de que a formiga seguinte siga o caminho mais curto é mais alta. Sendo assim, dada a diferença entre os intervalos de remarcação entre as trilhas e a volatilidade do feromônio, o feedback positivo favorece a convergência do fluxo para a trilha de menor comprimento. Vale notar que o funcionamento do mecanismo de retroalimentação é coletivo na medida em que só pode ocorrer com a participação de vários indivíduos, e que nenhum indivíduo é em si diretamente responsável pela consequência da formação ou não de uma trilha.

Tal estratégia torna possível que os indivíduos encontrem o caminho mais curto entre o ninho e a fonte de alimento sem depender da capacidade de integrar o ambiente em uma representação das posições do ninho e da fonte alimentar (GOSS et al., 1989). Essa é uma capacidade da trilha que não está presente no nível individual, e que apesar de operar coletivamente não depende de um controle ou organização central (BONABEAU et al., 1997; CAMAZINE, 2003; DENEUBOURG et al., 1990). Essa perspectiva é importante por ter mostrado que embora os desafios do ambiente possam envolver os indivíduos na execução de suas tarefas, a solução global pode ir além da contribuição individual, sendo determinante para o sucesso da colônia (JEANSON; DUSSUTOUR; FOURCASSIÉ, 2012; SASAKI et al., 2013).

\subsection{O estudo da orientação espacial e o comportamento}

Se por um lado o estudo do comportamento voltado para a orientação espacial responde imediatamente à um aspecto ecológico, por outro ele trata tipicamente de mecanismos fisiológicos internos. O contexto biológico no qual um animal se desloca no espaço, por exemplo, para busca de alimento, reprodução, migração, defesa de território, fuga de predador, constitui um fim para o mesmo. No entanto, a forma como ele é executado e por quê se dá dessa forma e não de outra, são perguntas que dizem respeito à processos internos de percepção, coordenação e posteriormente da execução. Nesse sentido, o estudo do comportamento de orientação espacial visa esclarecer, em última instância, também, quais são esses mecanismos internos e como operam. 
No que diz respeito aos mecanismos, apesar da diversidade de contextos e organismos, alguns padrões são recorrentes. Embora as informações sensoriais específicas envolvidas em cada caso sejam bastante diferentes, no que diz respeito a posição e direção no espaço, as operações são fundamentalmente as mesmas (BENHAMOU; POUCET, 1995; SHETTLEWORTH, 2010). Dentre estes mecanismos, talvez o mais comum seja a navegação cega, ou integração de trajetória. Nele, o deslocamento é pautado internamente, pelo próprio organismo, todas as localizações do espaço são obtidas em referência a si próprio e, por essa razão, é dito egocêntrico. O animal mantém continuamente uma atualização - uma integração no sentido matemático - sobre as informações de mudança de posição e direção em relação a si próprio e dentro desse sistema estabelece qual será o deslocamento visando o alvo.

Outra forma bastante conhecida é a orientação com o uso de pistas visuais. Estas podem ser proximais ou distais. Enquanto no uso de pistas proximais a pista constitui em si um atributo relacionado espacialmente à posição exata do alvo almejado pelo deslocamento, no uso de pistas distais a pista não marca a posição do alvo, mas serve como um indicador referencial da posição do alvo, constituindo uma referência intermediária para qual é atribuída uma informação direcional ou de distância que por sua vez se refere ao alvo final. Talvez o exemplo mais simples em que as duas formas podem ser observadas é no tradicional labirinto aquático de Morris (MORRIS et al., 1982). Quando o rato vê a plataforma ele se dirige diretamente à ela. Uma vez que o animal é treinado a nadar até uma plataforma sempre na mesma posição, quando ela é posteriormente retirada, ele continua nadando diretamente até aquela mesma posição, se guiando por uma pista distal que representa o alvo por estar justaposta ou próxima ao alvo em questão, até a plataforma. Em outra condição, em que a plataforma é submersa e a água é tornada opaca, o animal aprende a posição da plataforma usando referências visuais distais localizadas fora do labirinto. Uma evidência de que utilização de pistas proximais e distais são tarefas distintas é o fato de que a lesão hipocampal em ratos incapacita o aprendizado de pistas distais (MORRIS et al., 1982; WHITE; MCDONALD, 2002) entretanto, não compromete no caso de pistas proximais, sugerindo que essas capacidades são dissociadas.

Um caso clássico de uso de pistas distais é visto em insetos. Pistas ambientais conspícuas, como a posição do sol, também são utilizadas. No caso da posição do sol, de forma fisiologicamente integrada com o relógio endógeno do animal (MENZEL et al., 2005). 
Abelhas aprendem a direção de uma fonte de alimento em relação ao ângulo formado entre a saída do ninho e a posição do sol de forma que este sirva como uma bússola (VON FRISCH; LINDAUER, 1956). Conforme o sol se move no céu ao longo do dia, elas ajustam o ângulo de acordo com esse deslocamento, uma vez que seus relógios endógenos fornecem uma medida de quanto tempo se passou, e portanto, de como essa compensação pode ser feita. Essa função de ajuste é conhecida como efeméride solar.

A utilização de pistas visuais na navegação de insetos, no entanto, não utiliza necessariamente elementos discretos do campo de visão, podendo utilizar não somente mais elementos de referência, mas a imagem em si (sem necessariamente a identificação de elementos isolados) como padrão referencial. Num experimento clássico (TINBERGEN, 1938) em que dispunham pinhas em círculo ao redor da saída do ninho de uma vespa, e posteriormente, durante uma viagem externa da vespa, deslocavam o círculo de pinhas para uma proximidade, de forma que ao voltar, a vespa buscava sem sucesso a entrada do ninho no centro do círculo deslocado. No exemplo descrito (TINBERGEN, 1938) a vespa seria capaz de visualizar características do ambiente, memorizar na forma de uma imagem, e utilizar essa imagem como referência. No centro de onde estiver o círculo de pinhas, estará a entrada do ninho. Desde o experimento de Tinbergen com vespas, uma série de experimentos foram realizados mostrando de que forma as pistas visuais são utilizadas, e como os animais utilizam características das pistas como forma de associar informações sobre a direção ou posição do alvo do deslocamento.

Outra situação bastante conhecida em que a orientação por aprendizagem visual pode ser observada é nos voos de orientação (MENZEL; GREGGERS, 2015; MENZEL; MULLER, 1996) de abelhas e alguns outros insetos hymenopteros. Ao sair do ninho, a abelha se volta de frente para ele e faz vôos em arcos laterais curtos enquanto mantém-se olhando diretamente a entrada do ninho. O comprimento desses arcos vai gradualmente aumentando até que depois de alguns segundos, a abelha voa numa espiral ascendente de raio bastante grande, a ponto de se perder de vista, e então retorna ao ninho sem qualquer alimento, néctar ou pólen. Nesses voos de aprendizagem, um indivíduo memoriza a imagem do ninho sob vários ângulos, integrando-as numa perspectiva, de forma que possa posteriormente, quando passar a forragear, orientar-se e escolher sua rota (MENZEL, 2001; MENZEL et al., 2005). 
A utilização das pistas visuais através da memorização de imagens (imagens panorâmicas, ou 'snapshots') tornou-se uma ideia bastante aceita na medida em que foram testadas quais as características do meio que poderiam estar representadas na composição da imagem memorizada e no tipo de informação que essas características forneceriam à navegação. Numa série de estudos (CARTWRIGHT; COLLETT, 1983), abelhas foram treinadas a forragear numa fonte de alimento próxima da qual havia uma pista visual (cilindro preto). Após treinar a chegar no alimento na presença da pista, a mesma abelha era testada no mesmo ambiente controlado, no entanto, a pista era trocada por outra igual em todos os aspectos, exceto pelo tamanho. A substituição por uma pista com o dobro do tamanho levava a abelha a procurar a fonte de alimento próximo do que seria o dobro da distância. Análogamente, uma pista visual com a metade do tamanho levava uma abelha a procurar o alimento na metade da distância original. Ou seja, concluiu-se que a abelha utilizava o tamanho da pista visual como forma de avaliar a posição do alimento, voando até a posição em que o tamanho da pista no campo de visão tivesse o mesmo tamanho que na imagem retinal memorizada. Sendo assim, o tamanho das pistas visuais seria uma informação relevante utilizada pelas abelhas para saber posição e para calcular a rota de deslocamento.

Uma série de variações testadas corroboraram a hipótese de utilização da imagem retinal memorizada, e uma vez conhecido um aspecto relevante (tamanho das pistas), outras características possíveis relativas à imagem também foram testadas como fonte relevante de informações de posição e direção de deslocamento. Na presença de mais de uma pista visual, as abelhas buscam o alimento na posição em que os ângulos da pistas em relação ao alimento sejam do mesmo valor que na condição de treino. Combinados os fatores de ângulo e tamanho, foi possível observar que as abelhas preferiram buscar o alimento numa posição em que os ângulos estivessem corretos e os tamanhos das pistas fossem diferentes da condição treinada à uma montagem em que os ângulos das posições das pistas era variado e os tamanhos das pistas mantidos. Assim sendo, a informação sobre o conjunto de ângulos seria mais relevante para a localização do que o tamanho (forma). 
Dentre as questões levantadas, duas interessantes são o grau de processamento da imagem de referência e como elas são armazenadas na memória. Quanto à primeira, questiona-se se a imagem é processada, distinguindo-se elementos individuais, como alguns objetos específicos do campo de visão; ou se ela é em si uma representação geral e menos processada, ou ainda se essas representações coexistiriam como referências até certo ponto independentes. Questiona-se tanto do ponto de vista de aquisição e duração da memória, quanto do ponto de vista de estrutura. Se a imagem for menos processada ela tende a corresponder a campos receptivos mais iniciais na sequência de processamento neural, enquanto que a identificação de elementos individuais é mais posterior no processamento visual, e a reconstrução através da composição com diferentes elementos e suas relações de posição seria uma etapa ainda mais posterior no processamento neural das imagens. Na ocasião, julgou-se provável que as regiões cerebrais supostamente envolvidas seriam respectivamente os lobos ópticos e os corpos cogumelares, onde há integração do processamento visual que produz um mapa topográfico como representação do campo perceptivo visual, o que configura um processamento um pouco além das etapas iniciais.

Embora os mecanismos básicos sejam mais prontamente identificáveis, a questão do que de fato os animais aprendem sobre o espaço é mais difícil de responder (THORNDYKE; HAYES-ROTH, 1982). Uma possibilidade seria o aprendizado de uma série de respostas motoras correspondentes à presença dos estímulos específicos. A outra, seria alguma forma de representação do espaço em que são integradas as informações de posição de si, das referências e alvos, formando uma base para a computação das respostas necessárias para o direcionamento do deslocamento.

Embora os modelos de orientação espacial sejam um pouco diferentes dos modelos de aprendizagem associativa, eles são associativos no sentido de que dependem de estabelecer relações (métricas associativas) entre os elementos representados e daí exatamente que surge a ideia de mapa (O'KEEFE; NADEL, 1978a). Se os modelos de memória declarativa e não declarativa estabelecem hierarquias ou topologias relacionais entre os elementos (HELENE; XAVIER, 2007; XAVIER; COSTA, 2009), a orientação espacial depende de estabelecer relações topológicas, em que a relação é de alguma forma uma métrica. Se do primeiro modelo resulta uma capacidade de identificação dos elementos discretos do mundo, do segundo surge uma topologia de representação espacial. 


\subsection{Orientação espacial em formigas}

Há muito tempo que a orientação espacial em formigas é tópico de estudos. Um dos modelos mais estudados ao longo da história tem sido o retorno ao ninho em formigas do deserto. No deserto não há como utilizar feromônios para marcar as trilhas, e portanto, outras formas de orientação foram investigadas. Assim, esse é tido como um modelo animal de estudo das características individuais na ausência de estratégias coletivas dominantes, como a marcação de trilhas.

Wehner, além de produzir diversos estudos na área, apresentou uma perspectiva histórica interessante de dois pioneiros (WEHNER, 2016) do início do século passado. Victor Cornetz, trabalhando no deserto da Algéria, entre 1909 e 1910, já apontava que formigas retornavam ao ninho em linha reta, diferentemente do percurso exploratório de ida. Indo contra a visão também defendida na época, de que a volta seria uma execução inversa da memória proprioceptiva da sequência mecânica de movimentos executados na ida. Embora nunca tenha propriamente cunhado o conceito de integração de trajetória, ele se referia a "un sens de perception des directions absolues dans l'espace" como responsável pela capacidade de retorno em linha reta. Na mesma época, na Tunísia, Felix Santschi (1911), também estudando o comportamento de guiamento de formigas do deserto, demonstrou o uso do sol como referência. Tampando o sol e posicionando um espelho que o refletisse pelo lado oposto em relação à uma formiga, esta invertia sua direção de deslocamento no retorno ao ninho. Ele não só mostrou o uso do sol como bússola, mas também hipotetizou que as formigas teriam uma forma de corrigir o deslocamento do sol ao longo do tempo se tivessem alguma representação interna de tempo circadiano.

O retorno em linha reta para o ninho é o caso canônico da integração de trajetórias. Ao sair do ninho, uma formiga percorre um caminho aleatório em busca de alimento. Ao longo do trajeto, o que o mecanismo de integração de trajetória faz é ir somando, a cada etapa, a direção e a distância percorrida de forma a manter atualizado um vetor que aponte de volta para o ninho. Ao chegar ao alimento, ela simplesmente segue a direção desse vetor e retorna diretamente ao ninho, sem a necessidade de refazer o caminho de busca da ida (MULLER; R. WEHNER, 1988).

O mecanismo responsável por fazer com que a formiga possa perceber as distâncias percorridas necessário para a integração de trajetórias é um pedômetro (WITTLINGER, 2006). A utilização do pedômetro foi verificada ao se prolongar as patas de formigas antes do início do percurso de retorno ao ninho. Com as perna prolongadas, elas 
caminhavam o dobro da distância necessária para retornar. Não encontrando o ninho, começavam o comportamento típico de caminhar em círculos ao redor de onde este deveria estar. Analogamente, formigas que tiveram suas patas cortadas logo antes do início do retorno caminharam menos do que o necessário para alcançar o ninho, e começaram a busca pela entrada antecipadamente. Concluiu-se que, em função da observação da mudança das distâncias percorridas no retorno serem coerentes com a alteração do tamanho do passo, o número de passos continuava o mesmo. Sendo assim, elas percebem as distâncias percorridas contando os passos. Quanto testadas novamente, após percorrerem novamente o percurso de ida, elas passavam a percorrer a distância correta do ninho no retorno seguinte.

Outros mecanismos podem ser utilizados para a ajustar os erros da integração de trajetórias. A formiga pode corrigir sua direção usando como bússolas a posição do sol e o padrão de orientação da luz polarizada no céu (WEHNER RÜDIGER; SRINIVASAN, 2003). Além dessas pistas, ela pode aprender a associar direções (vetores locais) à outros elementos visuais fixos do cenário, utilizando-os como pistas visuais distais (COLLETT et al., 1992). As direções associadas, são relativas ao próprio estado do integrador de trajetórias naquela posição, de forma que este guiaria a aprendizagem do valor das pistas visuais distais (COLLETT; COLLETT, 2000).

Uma forma de se observar a navegação por memorização dos vetores locais é deslocar experimentalmente uma formiga no momento imediato em que ela chega ao ninho. Nesse momento, o seu mecanismo integrador de trajetórias está zerado, e não pode fornecer informações para a orientação. Colocada de volta na fonte de alimento, a formiga retorna orientando-se de acordo com os vetores locais associados às pistas visuais. Em caminhos já bem conhecidos por uma formiga, em locais com bastante elementos, a orientação segundo os vetores locais pode ser vantajosa, funcionando de modo a ajustar o erro do integrador de trajetórias (WYSTRACH; MANGAN; WEBB, 2015). Enquanto a formiga navega segundo os vetores locais, ela ignora temporariamente o global, porém, este continua sendo atualizado, de forma que o valor global da integração pode voltar a se sobrepor posteriormente (COLLETT et al., 1998; COLLETT; COLLETT, 2009). Enquanto a memória e aprendizagem são um produto de um acúmulo da experiência, o integrador tem seu funcionamento ininterrupto desde o momento inicial, funcionando independentemente da aprendizagem (CHENG et al., 2009), embora a aprendizagem das pistas visuais dependa dele. 
Uma forma de se comparar o papel da pistas visuais e a bússola solar é manipulando experimentalmente o ângulo da pista (COLLETT; COLLETT; WEHNER, 2001). Quando a formiga em questão está com vetor global zerado, a trajetória tende a se alterar de forma correspondente a alteração do ângulo da pista, apontando uma predominância dos vetores locais. Entretanto, quando o vetor global está disponível, a trajetória resultante é um balanço entre as duas informações. Sendo assim, a preponderância das pistas visuais locais ou da bússola solar são relativas ao estado (valor) do mecanismo de integração de trajetória (COLLETT; COLLETT; WEHNER, 2001).

A integração das pistas visuais e do mecanismo integrador de trajetórias depende também do estado interno de viagem da formiga. Forçando uma formiga a fazer caminhos diferentes na ida e na volta através da colocação experimental de barreiras, ela aprende pistas diferentes em cada caminho. Posteriormente, quando essa formiga é deslocada com o seu vetor global zerado e posta próxima ao caminho de ida, ela inicia um comportamento de busca aleatória do ninho, e embora cruze o caminho de ida, não o segue. Por outro lado, se nessa busca ela interceptar o caminho de volta, ela o segue diretamente e alcança o ninho. Sendo assim, memórias adquiridas na ida só servem na ida, e memórias adquiridas na volta só servem na volta (COLLETT; COLLETT, 2006; WEHNER et al., 2006), indicando que elas não teriam um valor posicional próprio, como num mapa.

Se o integrador de trajetórias é passivo e funciona constantemente, a memorização de um alvo de deslocamento ou pista visual é ativa. Uma formiga pode fazer manobras a fim de capturar imagens de ângulos diferentes, memorizar diferentes elementos do cenário (SCHWARZ et al., 2017). Por exemplo, quando uma formiga está voltando para o ninho, ela pode se voltar para trás, olhando na direção do caminho para o alimento para memorizar imagens panorâmicas do cenário vistas daquela posição no espaço (snapshots). Essas imagens, mesmo sem elementos discretos, podem ser utilizadas como referências posicionais (COLLETT; CHITTKA; COLLETT, 2013). Através do alinhamento da imagem retinal com memórias visuais prévias (alignment image-matching) há uma inferência de direção com base na diferença entre a imagem retinal e a imagem memorizada.

Nessa proposta de visão dos mecanismos de orientação em formigas apresentada até aqui, a seleção do mecanismo utilizado seria algo como uma caixa de ferramentas, em que uma delas é selecionada à cada instante, segundo algum mecanismo de seleção (COLLETT; CHITTKA; COLLETT, 2013). Os fatores de decisão sobre qual o mecanismo a ser utilizado numa dada circunstância dizem respeito à disponibilidade de pistas visuais, ao estado do integrador de trajetórias, à memória individual motora (ex: odômetro) e visual, e 
então, face às circunstâncias, o mecanismo de seleção operaria sobre a incerteza associada à cada um dos mecanismos (WYSTRACH; MANGAN; WEBB, 2015). Sendo assim, fica claro que a capacidade de navegar pelo ambiente depende de diferentes estratégias, e não só de um elemento.

Modelos mais recentes tentam reconstruir as redes neurais capazes de desempenhar a integração de caminhos (GOLDSCHMIDT; MANOONPONG; DASGUPTA, 2017), ou mesmo redes capazes de integrar as memórias, se contrapondo à visão de que as formigas guardam e resgatam a memória de imagens discretas de forma independente umas das outras (WYSTRACH et al., 2013).

\subsection{Bases neurais da orientação espacial}

A orientação espacial nos animais é dependente da capacidade de formação, armazenamento e resgate de memórias espaciais. Essas memórias espaciais podem ser desde imagens, associação de imagens e direções, ou mesmo estados internos do indivíduo. Muitos trabalhos tentaram avaliar quais são as características de um ambiente que seriam percebidas pelos animais e que dariam informações direcionais ou posicionais utilizadas na orientação. Complementarmente, buscaram avaliar como essas informações são memorizadas e utilizadas posteriormente observando as estruturas neurais subjacentes à aquisição e performance diante da utilização dessas informações espaciais.

Embora muitos mecanismos sejam comuns ou ao menos bastante semelhantes entre os mais diversos animais, a compreensão das bases neurais de mecanismos presentes na orientação espacial se desenvolveu principalmente no estudo de mamíferos, especialmente de roedores. Ainda assim, modelos estereotípico de orientação estão associados aos estudos em outros grupos. A navegação por integração de trajetória e o retorno ao ninho em linha reta é tipicamente associado às observações de formigas Catagliphysis. Da mesma forma, o modelo de utilização de pistas visuais distais conspícuas como o sol e orientação pelo ângulo do plano de polarização da luz é frequentemente associado às abelhas. Já para mecanismos de orientação geomagnética e celestes os organismos modelos são as aves. E para representações internas pautadas em vias neurais complexas são os mamíferos. 
Se por um lado essa divisão dos mecanismos é oportuna, dado que cada um desses organismos é um ótimo modelo de estudos para o respectivo mecanismo, por outro lado fica a impressão de que cada um deles somente apresenta o mecanismo do qual é modelo. Essa ideia é particularmente crítica no caso de insetos por se imaginar que seu sistema nervoso, mais rudimentar, seria incapaz de utilizar mecanismos sofisticados ou mesmo de relaizar a integração de diversos mecanismos, como os observados em mamíferos.

$\mathrm{Na}$ segunda metade da década de sessenta do século passado, diversos pesquisadores buscavam entender os mecanismos celulares neurais por trás do aprendizado. O modelo de aprendizagem associativa já era presente desde os trabalhos de Pavlov e Thorndike (apud WASSERMAN; MILLER, 1997) a partir da década de vinte do século passado. Além disso, o modelo neural de aprendizagem proposto por Hebb (apud MAGEE; JOHNSTON, 1997), de que neurônios cuja ativação de um levasse a ativação do outro teriam suas conexões reforçadas, carecia de observações e de mecanismos celulares que pudessem suportá-lo. Mesmo porque a idéia de que para a formação de novas memórias não seria necessária a formação de novos neurônios, mas sim o aumento das conexões entre eles, já era um elemento suposto por Ramon y Cajal (JONES, 1994).

Primeiramente, foi observado o fato de que a estimulação em fibras da via perfurante provocava nas células granulares do giro denteado do hipocampo a formação de potenciais excitatórios pós sinápticos seguidos por potenciais inibitórios (ANDERSEN; HOLMQVIST; VOORHOEVE, 1966). Com base na diferença de tempo entre a excitação e a inibição e dada a estrutura do hipocampo e suas regioẽs (CA1, schaffer e CA3) concluiu-se que a excitação e inibição eram produzidas por sinapses que ocorriam em áreas diferentes, indicando que a modulação dos potenciais estava relacionada à conexão entre áreas diferentes .

Entretanto, até este momento ninguém explorava esses fenômenos de potenciação como mecanismo de aprendizagem. Entre outros fatores, porque a duração da excitabilidade aumentada era curta, em torno de alguns minutos. (LØMO, 2003). Mas posteriormente, em estudos subsequentes (BLISS; LØMO, 1973), foi observada uma resposta intensa, tanto em amplitude quanto em número de disparos, com redução da 
latência durante a série de estímulos seguido de um período curto de depressão (1-2s), e a partir de alguns minutos, uma resposta a um novo estímulo era muito mais intensa (em número e amplitude) e rápida (baixa latência) se comparada ao mesmo estímulo na condição pré condicionamento. Esse aumento de intensidade de resposta perdurava por até 10h, começando a decair após 8h. Mais tarde foi descrito todo o mecanismo da potenciação de longo prazo, desde os aspectos moleculares, aumento da transcrição de genes, vias bioquímicas e tipo de receptores envolvidos (LØMO, 2018).

O hipocampo já era objeto de estudo de cientistas que estavam pesquisando memória. Em 1957 havia sido descrito por Milner e Scoville o caso do paciente H.M. (SCOVILLE; MILNER, 1957), que tinha passado por uma cirurgia de remoção bilateral de parte do lobo temporal medial incluindo o hipocampo. Esse caso foi de extrema importância para a neurociência e estudo sobre a memória e aprendizagem, pois embora o paciente apresentasse uma amnésia anterógrada total, sendo incapaz de formar memória sobre fatos e eventos ocorridos após a cirurgia, ele era capaz de melhorar seu desempenho em novas tarefas aprendidas, por exemplo, ao longo dos treinos ele reduzia o tempo de reação e melhorava sua performance em tarefas como desenhar num papel olhando somente a imagem da mão e desenho no reflexo de um espelho (CORKIN, 2002). Diante disso, podiase concluir que a memória declarativa e a não-declarativa eram dissociadas, e o hipocampo parecia ser uma região implicada na capacidade de formação de memória episódica, sendo portanto, importante para a memória e aprendizagem. Sendo assim, já havia algum conhecimento sobre o envolvimento do hipocampo na formação de memória na formação de memória de longo prazo. A observação da potenciação de longo prazo vinha, em certa medida, de encontro à visão de aprendizagem por associação, em que a presença do estímulo condicionante reforçava uma resposta, uma via. No entanto, outra perspectiva seria apontada na orientação espacial, em que a representação de posição não tinha um valor em si, ou algo a ser associado (O'KEEFE; NADEL, 1978).

Monitorando o comportamento de neurônios em CA1 de ratos numa caixa durante seus comportamentos normais de alimentação, ingestão de água, interação com objetos, O'Keefe observou que algumas disparavam somente quando o animal estava numa determinada posição do labirinto e olhando numa determinada direção. E que essa posição era específica, de forma que em outra posição, outra célula que disparava, também somente nessa posição. Outras células apresentavam uma taxa de disparos basal, mas que 
na proximidade de uma posição específica essa taxa se tornava máxima (O’KEEFE; DOSTROVSKY, 1971). A essas células, O'Keefe deu o nome de células de lugar (place cells). Diferentes células de lugar disparam especificamente para os seus lugares correspondentes (campo de lugar, ou place field), e da combinação da atividade de diferentes células de lugar emergiria uma representação neural como um mapa espacial de um ambiente (O'KEEFE, 1976; O'KEEFE; CONWAY, 1978). A partir dessas observações foi sugerido que o hipocampo seria responsável por produzir um mapa como referência espacial.

Além disso, ele mostrou que esse mapa representado na atividade neural persiste ao longo do tempo e que, portanto, as células de lugar teriam funções de memória (O'KEEFE; CONWAY, 1978; O'KEEFE; SPEAKMAN, 1987). O hipocampo poderia conter múltiplos mapas, formados pela combinação de atividades de conjuntos parcialmente repetidos de células, acionados em contextos ou lugares diferentes. Dessa forma, um conjunto específico de atividade representaria um lugar, e outro conjunto específico poderia representar outro lugar. O remapeamento, ou a alteração do padrão de atividade de um subconjunto de células em lugares diferentes era gradualmente aprendido e se tornava mais estável ao longo do tempo (LEVER et al., 2009). Dessa forma, as células de lugar são substratos de processos de memória e aprendizado, em que a memória é o padrão de ativação de um conjunto específico de células representando uma localidade.

As células de lugar, em conjunto com as células de grade e de direção que foram descritas posteriormente (HAFTING et al., 2005) representam não só onde o animal está, mas também de a direção de deslocamento e antecipando a posição futura (FERBINTEANU; SHAPIRO, 2003). E nesse sentido, se parece muito contrastante a ideia de que haja formação de memória e aprendizagem num processo contínuo como o de orientação espacial e navegação em que as relações de associação nem sempre são tão claras ou marcantes, é, por outro lado, razoável que o mapa cognitivo atue como um sentido espacial de representação e aprendizagem do meio. Um sentido virtual, dado que, diferentemente de outros não possui receptores próprios ou específicos mas que constrói o percepto a partir da integração de outras modalidades sensoriais. 
Os estudos em neurofisiologia elucidaram bastante do funcionamento dos mecanismos de orientação espacial, inclusive apontando a existência de um mapa cognitivo e sediando-o no hipocampo e no cortéx entorrinal (HAFTING et al., 2005). Embora esse modelo seja atualmente bastante robusto, a ideia de mapas cognitivos se torna mais frágil se generalizada para animais sem hipocampo e com sistemas nervosos menos desenvolvido. Os vertebrados, de teleósteos à aves, tem uma região telencefálica homóloga ao hipocampo dos mamíferos (GUPTA et al., 2012). Embora as diferenças neurais podem ser um fator de fragilidade, por outro podem ajudar a compreender melhor como o sistema funciona. Os estudo em aves por exemplo, que tem um sistema nervoso bem desenvolvido, inclusive o hipocampo, tem contribuído de forma interessante para a compreensão de como funciona o mapa cognitivo (VARGA et al., 2017).

Já invertebrados não possuem nem hipocampo nem sistema nervoso bem desenvolvido se comparados à mamíferos ou aves. No entanto, insetos claramente são capazes de executar diversos comportamentos complexos e sofisticados do ponto de vista da orientação espacial, à ponto de sugerir que ao longo da evolução tenham surgido diversas soluções para as questões ecológicas e de comportamento que envolvem estratégias e comportamentos semelhantes de deslocamento no espaço. Além disso, o número de estudos apontando que eles podem utilizar muitos desses mecanismos neurais descritos aumentou com a aplicação de técnicas avançadas de neurofisiologia em insetos (VARGA et al., 2017).

Tanto os corpos cogumelares quanto o complexo central são regiões aparentemente envolvidas de alguma forma na orientação em insetos. Os corpos cogumelares são regiões para onde convergem vias sensoriais de várias modalidades (YAGI et al., 2016). Mais recentemente tem ganhado foco o complexo central (VARGA et al., 2017) em que há também formação de memória visual e que cedia a bússola celestial (TURNER-EVANS; JAYARAMAN, 2016). Num experimento análogo ao labirinto de Morris para insetos (MIZUNAMI; WEIBRECHT; STRAUSFELD, 1998) em que uma barata deve aprender a posição cujo assoalho seja mais frio (em outros pontos do labirinto ele é mais quente), baratas lesionadas em áreas específicas dos corpos cogumelares apresentaram piora no desempenho apesar de manterem capacidade de identificar as pistas visuais. Além disso, moscas mutantes para um gene expresso no complexo central relacionado ao aprendizado são incapazes de aprender uma tarefa semelhante (VARGA et al., 2017). 
O fato do sistema nervoso dos insetos ser mais simples do que o dos mamíferos sempre foi apontado como um fator de limitação das capacidades de orientação espacial. De fato, a complexidade do substrato neural envolvido na capacidade de representação espacial na forma de um mapa que envolve o córtex entorrinal e o hipocampo é grande, requer a interação entre estruturas cefálicas diferentes. No entanto, cada vez mais se observa que essas capacidades são dadas por propriedades neurais presentes em diversos outros organismos, não só em mamíferos. Cada vez mais, mecanismos neurais igualmente sofisticados são encontrados no sistema nervoso de insetos (MENZEL; BENJAMIN, 2013).

\subsection{Comportamento coletivo e o uso do espaço em formigas}

\subsubsection{Comportamento coletivo}

No sistema nervoso dos mamíferos é necessário que uma rede de neurônios seja estruturada de forma particular, para que no final do processamento, seja capaz de produzir formas de representação do espaço codificadas na atividade de um conjunto específico de células (AGARWAL et al., 2014; BUZSAKI, 2015). Sendo assim, a capacidade de orientação não é produto exclusivo do funcionamento de um neurônio específico. Mesmo porque a forma de funcionamento deste neurônio nem o distinguiria de outros, que codificam outras informações. Assim como o sistema nervoso, o comportamento coletivo em formigas é um caso clássico em que as capacidades exibidas pelo resultado global da interação entre os indivíduos é qualitativamente diferente das capacidades individuais (JEANSON; DUSSUTOUR; FOURCASSIÉ, 2012). Dessa forma, não é necessário que se estabeleça uma correspondência direta entre neurônios e formigas para que seja razoável que se busque em comportamentos coletivos propriedades distintas das capacidades individuais de seus componentes. Basta que se compreenda que alguns sistemas possuem a mesma lógica de relação entre níveis diferentes de organização, cada qual operando segundo seus próprios mecanismos, características e propriedades (HOFSTADTER, 1979). Considerando o fato de que, além disso, cada formiga possui um sistema nervoso próprio, individualmente capaz de aprender e tomar decisões (DORNHAUS; FRANKS, 2008), os resultados coletivos possam ser tanto consequência do fato de que são vários indivíduos - e isso por si só já é capaz de produzir comportamentos sofisticados - como podem ser resultado das interações entre os indivíduos. Sendo assim, é justificável que se observe no comportamento coletivo 
comportamentos comparáveis à capacidades cognitivas em animais com sistema nervoso mais desenvolvido (COUZIN, 2009; COUZIN et al., 2002; HEYMAN et al., 2017; PERRY; BARRON; CHITTKA, 2017; SASAKI; PRATT, 2018; SEELEY, 2009).

Os processos coletivos de formação de trilha, conforme apresentados, possibilitam não somente que as formigas se desloquem do ninho ao alimento e retornem, mas que tendam a fazer a trilha mais curta entre os dois. Entretanto, a formação da trilha do ponto de vista da escolha espacial do trajeto não é o único aspecto das trilhas de forrageamento em que se pode observar comportamentos coletivos dados pelas interações segundo mecanismos individuais. O fluxo em si pode também ser regulado por mecanismos dessa natureza, como a taxa de interação entre indivíduos e de retorno de indivíduos transportando alimento (PLESS et al., 2015; PRABHAKAR; DEKTAR; GORDON, 2012). As interações podem regular o balanço entre o número de formigas que volta para dentro do ninho, permance na entrada disponível ao recrutamento, ou que deixa o ninho para forragear (UDIANI; PINTER-WOLLMAN; KANG, 2015). A disposição espacial dos recursos também afeta a formação espacial das trilhas uma vez que aparentemente há uma minimização do custo, conforme descrito pela minimização do custo de associação de nós (alimento e ninho) num modelo formação de redes (BOTTINELLI et al., 2015), que parece corresponder ao observado em colônias de formigas Pogonomyrmex barbatus. Ou ainda, controlando parâmetros como densidade de recursos, tamanho do recurso e sistema de recrutamento, observou-se que sempre há uma modulação da proporção de recrutadoras que maximiza a quantidade de recursos forrageados durante um dado período (JAFFE; DENEUBOURG, 1992).

A forma como as formigas se organizam no forrageamento também pode responder à qualidade do alimento. A quantidade de formigas Atta cephalotes numa trilha varia de acordo com a qualidade do alimento (JAFFE; HOWSE, 1979) e com a duração da privação alimentar. Até mesmo o estabelecimento da trilha preferencial pode ser impactado pela qualidade do alimento, uma vez que a intensidade da convergência para a fonte de recurso de maior qualidade pode ser quantitativamente correspondente à diferença de qualidade entre as fontes disponíveis (PRICE et al., 2016), ou ainda, menor à medida em que todas as fontes, apesar de diferentes, apresentem maior qualidade. 
Aspectos de manutenção da trilha também podem influenciar a dispersão espacial. Por exemplo, quando há a redução da deposição de feromônio na presença de muitos indivíduos (CZACZKES, 2014). Esse é um mecanismo adicional de retroalimentação negativa que ajudaria a fazer com que as trilhas fossem flexíveis o suficiente para mudar de caminho quando soluções melhores aparecem. Como se torna evidente neste caso, há um conflito entre a capacidade de organizar e focar o fluxo de forrageamento e a flexibilidade das soluções. Isso pode ser evidenciado experimentalmente com a inversão de posição de alimentos de qualidades diferentes. Colônias que se focam muito na opção de maior qualidade são inferiores na capacidade de inversão (LATTY; BEEKMAN, 2013). Uma vez que ambientes podem sofrer variações de disponibilidade de alimento mais ou menos rápidamente, a flexibilidade pode ser um aspecto bastante relevante para o sucesso de forrageamento de uma colônia. A forma como se dá esse balanço entre a flexibilidade e a organização pode, inclusive, ser definido por fatores como a marcação feromonal e dinâmica de interação (TABONE; ERMENTROUT; DOIRON, 2010), ou mesmo por dinâmicas particulares do fluxo, em que as preferências podem ser atenuadas (ZABZINA et al., 2014), permitindo uma readequação à condições diferentes.

A forma como os indivíduos se comportam é um aspecto chave no estudo de como os padrões globais surgem e se mantém (SUMPTER, 2006). Esse aspecto é bastante evidente em situações em que as formigas são confrontadas com algum desafio particular. Por exemplo, regras individuais de prioridade de passagem, que se tornam evidentes em situações de densidade muito alta de formigas numa trilha, são responsáveis por garantir a manutenção da eficiência no transporte de folhas (DUSSUTOUR et al., 2009b). Formigas retornando com alimento ao ninho são seguidas por formigas não transportadoras, que apesar de terem sua velocidade reduzida em função da posição em sequência de uma transportadora, não a ultrapassam, de forma que a velocidade média do fluxo e a taxa de retorno de folhas não é prejudicada pelo tempo extra perdido por encontros de cabeça extra causados pelas ultrapassagens. Além disso, a passagem com alternância de grupos em sentidos diferentes também promove a redução do tempo que seria gasto com encontros. Ou ainda, quando colocada uma restrição de altura na passagem das formigas, elas passaram a cortar fragmentos menores de folhas (DUSSUTOUR et al., 2009a). Entretanto, o corte reduzido era antecipado, elas o faziam diretamente na fonte, não tendo que recortar novamente na passagem. Além disso, a porção de formigas transportadoras na trilha aumentou de forma que não houve queda na taxa de chegada de folhas na colônia. 


\subsubsection{O comportamento coletivo e a dispersão pelo espaço}

A organização do trabalho na colônia e suas dinâmicas observáveis são fruto de processos de organização social. Aspectos da trilhas como otimização e flexibilidade, a interação entre comportamentos individuais e padrões globais de exploração não podem ser separados do comportamento coletivo como mecanismo de organização espacial de origem social. Inicialmente, ao se tratar da otimização coletiva, foi definida uma função de decisão individual (GOSS et al., 1989) para avaliar a evolução temporal dos fluxos nas trilhas a partir de alguns parâmetros empíricos sobre o fluxo. Com o tempo, surgiram variações do modelo propondo-o como algoritmo para simular esse comportamento em diferentes desafios espaciais (DORIGO; DI CARO, 1999; DORIGO; STÜTZLE, 2004; MARCO DORIGO, MAURO BIRATTARI, 2006) e modelos metaheurísticos mais sofisticados foram desenvolvidos. O primeiro, e talvez mais conhecido, é o Ant System (DORIGO; MANIEZZO; COLORNI, 1996). Mais tarde, tanto este como os posteriores passaram a ser coletivamente conhecidos como ACO (Ant Colony Optimization). De forma geral, esses modelos incorporam a função decisão individual original e adotam algumas premissas sobre as capacidades individuais para que o modelo seja genérico o suficiente para resolver diversos tipos de problemas de otimização e funcionem independentemente da estrutura espacial em que se situam.

A medida em que o ACO foi modificado para se tornar mais eficiente e geral enquanto algoritmo de solução de problemas de otimização combinatória, foram adotadas premissas comportamentais desvinculadas da intenção inicial de descrever o comportamento enquanto fenômeno biológico (BARBOSA et al., 2013; JAYADEVA et al., 2013). Não é estranho que os estudos biológicos tenham se mantido usando majoritariamente a versão original, basicamente sugerindo alterações na função de decisão (PERNA et al., 2012; VON THIENEN; METZLER; WITTE, 2015) face os resultados respectivamente obtidos. De fato, as premissas originais quanto às capacidades individuais das formigas são razoáveis, consistindo basicamente de que os indivíduos não apresentam vieses prévios em relação às decisões, sendo todas essas tomadas de acordo com a função de decisão, o que implica que elas sejam capazes de perceber numa bifurcação a intensidade da marcação feromonal em cada uma das trilhas possíveis. No entanto, há questões pontuais importantes se pensarmos o como o comportamento de dispersão no espaço ocorre. A exploração de uma fonte alimentar depende da formação de uma trilha de ida e de volta até o alimento e o modelo sugere sempre que estas sejam as mesmas. 
Embora o caminho da ida siga as probabilidades conforme descrito (seguindo um padrão exploratório livre de início e otimizando a distância pouco a pouco), o caminho de retorno é determinístico, dado pela inversão do caminho na ida, eliminando-se as repetições que houverem. Isso impõe que uma vez encontrada fonte de alimento, o indivíduo muda do estado de ida para o estado de volta.

Alguns experimentos com labirintos complexos foram realizados, mostrando a capacidade de formigas em achar a solução de problemas espaciais tão complexos quanto a tarefa conhecida como torre de Hanoi (REID; SUMPTER; BEEKMAN, 2011). Além de corroborar as expectativas de otimização, neste caso, não somente elas estabeleciam a trilha mínima, mas quando esta era bloqueada, as formigas formavam uma nova trilha mínima global ao invés de somente criar um desvio na trilha já estabelecida, o que levaria a uma solução sub ótima, apresentando uma flexibilidade surpreendente.

O impacto dos comportamentos individuais também pode ser observado nos padrões globais de dispersão. Uma possibilidade é de que eles sejam amplificados, de forma a determinar o padrão coletivo. Por exemplo, individualmente as formigas tendem a caminhar junto às paredes de uma área delimitada. Num labirinto com trilhas bifurcadas em que um dos caminhos possui parede e o outro não (ponte suspensa), o viés individual acarreta na convergência na maioria das vezes para a trilha com paredes (DUSSUTOUR; DENEUBOURG; FOURCASSIÉ, 2005). Outra possibilidade é a de que os comportamentos individuais não determinem nem comprometam o padrão global, mas ainda influenciem a dispersão espacial. Mesmo porque diante de casos em que há um conflito entre seguir por uma trilha marcada por feromônios e uma pela qual um indivíduo tenha previamente seguido com sucesso no forrageamento, é observado que dependendo da intensidade de marcação e do sucesso prévio obtido ele siga pela trilha que utilizou anteriormente, mesmo que somente a outra esteja marcada por feromônios (CZACZKES et al., 2012; GRÜTER; CZACZKES; RATNIEKS, 2010). Por exemplo, individualmente as formigas tendem, numa bifurcação, a seguir pela alternativa de menor desvio em relação a direção original do seu deslocamento (JACKSON; HOLCOMBE; RATNIEKS, 2004).

Os efeitos desses aspectos individuais são evidenciados na dispersão espacial quando esta é observada para além da otimização de trilhas. Num labirinto com diversas bifurcações, apesar da maioria do fluxo convergir para uma trilha mínima, o comportamento 
individual de preferencia pelo menor angulo em bifurcações assimétricas produz uma maior dispersão do fluxo (VITTORI et al., 2006). A marcação feromonal não é direcional, indica a direção, mas não os sentidos de ida e de volta, entretanto os ângulos das bifurcações podem estar associados a um sentido (geralmente nas trilhas na natureza a volta tende a apresentar mais bifurcações com ângulos assimétricos do que a ida), de forma a servirem como referência espacial. A variação dos ângulos das bifurcações pode provocar alterações nas dispersões espaciais na medida em que bifurcações simétricas reduzem a quantidade de referências espaciais (GARNIER et al., 2009). Todos esses casos são interessantes por mostrarem que mesmo como formigas que são dependentes de comunicação feromonal, e visualmente pouco capazes utilizam também ângulos de elementos espaciais para orientação. Além disso, são especialmente interessantes por demonstrarem como a utilização de marcação feromonal não encerra as explicações e possivelmente o repertório de mecanismos das formigas nas estratégias de dispersão pelo espaço.

Embora a exploração tenha sido estudada do ponto de vista espacial (DENEUBOURG et al., 1990; DETRAIN et al., 1991), os aspectos observados foram a utilização de marcação feromonal e a dinâmica de crescimento do fluxo exploratório, de forma que não foram avaliadas as estratégias de balanço entre as relações de compromisso entre organização e flexibilidade, exploração e forrageamento. Formigas cortadeiras enfrentam diversos desafios espaciais na medida em que forrageiam em diferentes fontes, constroem diversas saídas do ninho e formam trilhas bastante longas interligando os diferentes pontos dessa complexa organização (SILVA et al., 2013). Diante desses desafios, os mecanismos de regulação das atividades agem de forma que os ajustes às múltiplas necessidades esteja sob algum aspecto refletido nas dispersões pelo espaço e nos comportamentos do ponto de vista da ocupação do espaço. Assim, se pretende observar o comportamento coletivo das formigas em um labirinto que oferece a possibilidade de comparação dos fluxos reais de milhares formigas, medido por milhões de viagens individuais, aos fluxos ajustados por modelos, na busca da integração dos aspectos oriundos de um senso puramente individual necessários para gerar um senso de percepção de direções absolutas no espaço. 
2. Objetivos 
O objetivo do trabalho foi avaliar como a dispersão espaço-temporal das formigas de uma colônia reflete tanto o esforço exploratório quanto o de forrageamento. Para isso, buscou-se estabelecer formas de comparar quanto da dispersão decorre de cada um desses comportamentos. No entanto, uma vez que são indissociáveis, a dispersão deve refletir, a cada instante, um ponto de balanço entre os dois. Enquanto a convergência do fluxo para o caminho mínimo entre o alimento e a colônia é um indicador da atividade de forrageamento, a dispersão por outras partes do labirinto, incluindo uma trilha simétrica à de maior fluxo, é um indicador do comportamento exploratório. Sendo assim, o projeto tem por objetivo entender de qual forma a dispersão observada representa o desempenho desses dois comportamentos.

Para alcançar tal objetivo geral foram definidos como objetivos pontuais:

- Estabelecer um desafio de natureza espacial para estudo da ocupação do espaço, na forma de um labirinto radial hexagonal duplo concêntrico.

- Estabelecer método de avaliação detalhado dos fluxos nesse labirinto por meio de software desenvolvido como parte deste trabalho.

- Avaliar a distribuição de fluxo em duas condições: com disposição de folhas (alimento) na bandeja central da colônia (controle), ou em bandeja distante (experimento), no segundo circuito radial.

- Descrever tais fluxos em função da ocupação ao longo de 67 horas (avaliação dos fluxos), de sua estrutura de ocupação (caracterizada pela entropia) e de aspectos individuais (como o impacto dos fluxos estabelecidos e da tomada de decisão em função de ângulos). 
3. Materiais e métodos 


\subsection{As colônias}

Foram realizadas 5 réplicas experimentais. Para cada uma delas foi utilizada uma subcolônia de Atta sexdens rubropilosa procedente de uma colônia original diferente. Cada subcolônia consistia em uma panela de fungo utilizada para a criação das colônias em biotério. A panela de fungo tem cerca de 5 litros. As colônias são mantidas no biotério de formigas do laboratório de Ciências da Cognição do Instituto de Biociências. Nos experimentos, as subcolônias foram levadas para o laboratório de experimentação.

\subsection{Manejo experimental da colônia}

A sala onde foram realizados todos os experimentos não possui janelas, a iluminação é artificial, controlada por temporizadores. A temperatura da sala foi mantida à $23^{\circ} \mathrm{C}$ durante todo o período de aclimatação e de realização do experimento com uso de aparelhos de ar-condicionado programáveis. A umidade foi regulada com o uso de umidificadores de ar por nebulização, ligados em temporizadores e com ventoinhas acopladas para proporcionar uma dispersão mais uniforme da umidade pela sala. Tentouse manter a umidade da sala em torno de $70 \%$ durante todo o período de aclimatação e experimento.

Para aclimatação, pelo menos dois dias antes de cada experimento, a subcolônia a ser utilizada foi separada da colônia original e permaneceu na caixa central do labirinto experimental cujas saídas estavam todas fechadas impedindo o acesso ao restante do labirinto. Durante esse período a alimentação foi composta por folhas de Acalypha sp. em quantidade reduzida e água. No dia de início, a colônia foi privada de alimentação até a abertura das trilhas e início de fato do experimento. Todo o lixo e qualquer resto de folhas presentes na caixa central do labirinto antes do início do experimento eram retirados. Tal procedimento de limpeza era repetido diariamente, de forma a evitar o acúmulo de restos de alimento na caixa central. Durante a aclimatação, a iluminação da sala foi mantida em 12 horas de claro e 12 de escuro.

\subsection{O labirinto}

Foi construído um labirinto hexagonal duplo concêntrico, composto por treze caixas hexagonais de acrílico, interconectadas num arranjo específico (figura 1) por 16 canaletas (trilhas) de pvc. Cada caixa é um hexágono regular com $23 \mathrm{~cm}$ de aresta, com exceção da 
caixa central, onde fica a colônia, que é maior, com $32 \mathrm{~cm}$ de aresta. Todas as trilhas possuíam a mesma largura de $8,5 \mathrm{~cm}$ e de comprimentos variando de acordo com a posição no labirinto. As trilhas do anel externo possuíam $1 \mathrm{~m}$, as do anel interno $35 \mathrm{~cm}$ e as de conexão entre anéis ou entre a colônia e o anel interno possuíam $25 \mathrm{~cm}$ de comprimento. Sobre cada uma das dezesseis trilhas, aproximadamente na metade do seu comprimento, foi colocado um suporte de acrílico transparente de aproximadamente $2,5 \mathrm{~cm}$ de largura, no qual foi fixado uma câmera. As câmeras ficaram a uma altura de aproximadamente $13,5 \mathrm{~cm}$ do leito da trilha.

Figura 1. Labirinto experimental com as trilhas numeradas.

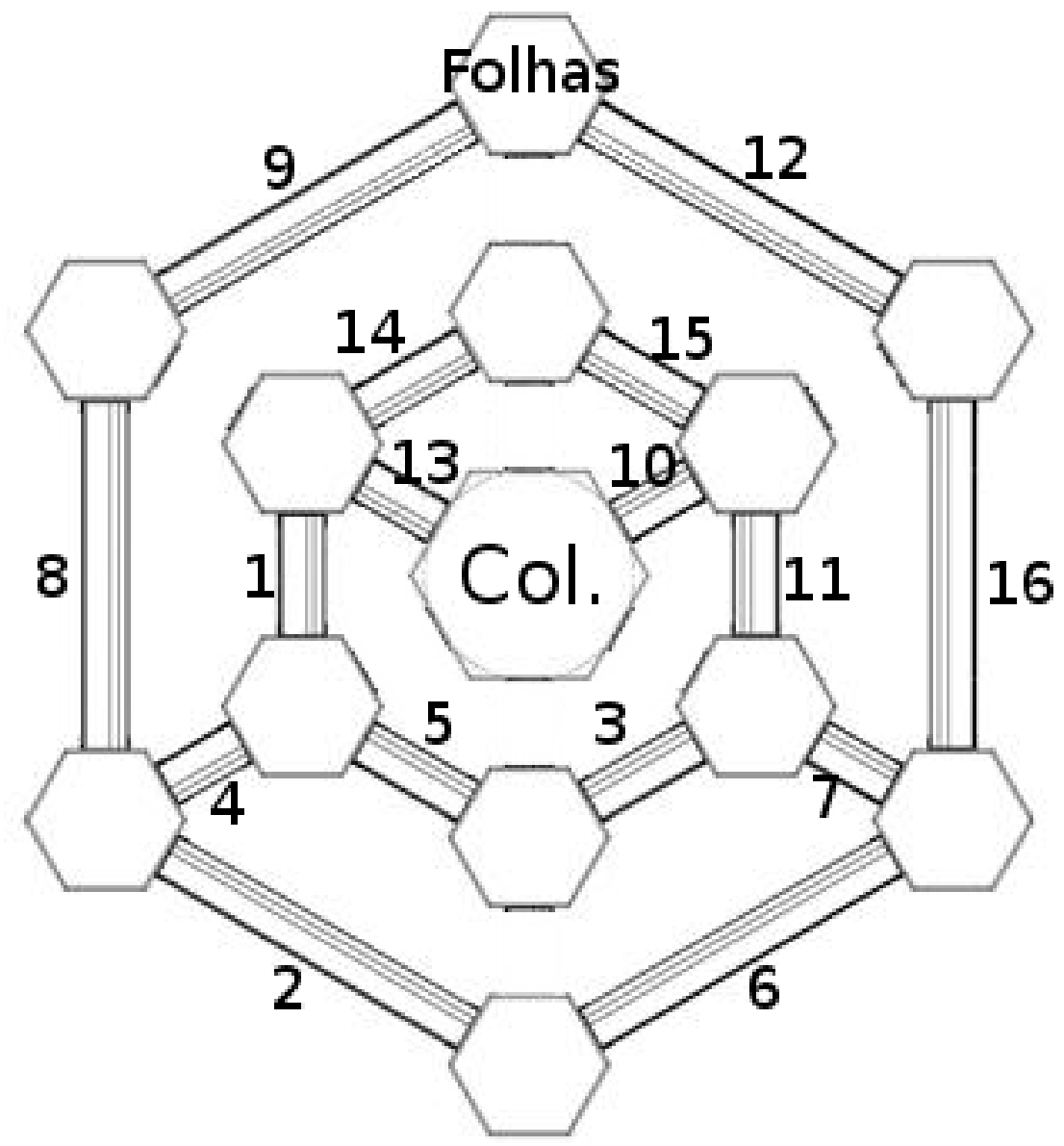

A colônia foi colocada no centro (Col.) e as folhas na bandeja de alimentação. A numeração indica a disposição das câmeras no labirinto.

Em razão do arranjo específico das dezesseis trilhas o labirinto apresenta algumas particularidades. A primeira é que a colônia está na posição central. Outro aspecto é que o labirinto apresenta uma simetria bilateral em relação à colônia. Tanto os hexágonos dos anéis quanto as conexões entre eles são bilateralmente simétricas. Além disso, a caixa onde são colocadas as folhas nos experimentos é a caixa mais distante da colônia. Uma 
das consequências é que todos os caminhos que levam da colônia à caixa com folhas são lateralmente simétricos. Entre eles, há dois caminhos mínimos simétricos formados pelas seguintes trilhas: $[13,1,4,8,9]$ e $[10,11,7,16,12]$.

Antes do início de cada experimento, passou-se com pincel uma mistura de álcool etílico com talco nas bordas superiores de todas as trilhas e caixas do labirinto porque quando sêca, o talco evita a fuga de formigas. Após a realização de cada experimento o labirinto foi completamente desmontado e cada uma das partes foi lavada com água, detergente, multi limpante, álcool etílico e enxaguados com água novamente.

\subsection{O experimento}

Para o grupo experimental, as folhas de Acalypha sp. foram oferecidas na caixa de alimentação, conforme indicado na figura 1 , enquanto no grupo controle, as folhas foram colocadas na caixa central, juntamente à colônia. Não há qualquer outra diferença na realização do experimento entre os dois grupos.

A realização do experimento ocorreu após dois dias de aclimatação em privação de alimento, sempre iniciando exatamente às 17:00, com a abertura simultânea das duas saídas da caixa central e o início das gravações de todas as dezesseis câmeras. No grupo experimental, folhas frescas foram colocadas na caixa de alimentação imediatamente antes do início, enquanto no caso do grupo controle, as folhas foram colocadas na caixa central, também imediatamente antes da abertura das trilhas. Os experimentos seguiram com gravação constante das dezesseis câmeras ao longo das 67 horas seguintes, por três dias além do inicial, encerrando-se às 12:00 do quarto dia. Os vídeos foram posteriormente analisados pelo software de contagem, que registra o momento e a direção de cada formiga que passa por um vídeo.

\subsection{O sistema de gravação}

As câmeras, posicionadas sobre as trilhas, eram todas analógicas de resolução de 480 pixels de altura por 640 pixels de largura em sistema de varredura entrelaçada. As câmeras foram todas conectadas por cabos auxiliares a uma placa de captura GeoVision® fixada numa parede do laboratório. Essa placa estava conectada à um servidor fora da sala de experimento. Neste servidor (Windows $7 \AA$ ) foi instalado o software de gerenciamento de 
monitoramento e gravações da GeoVision (GV-800 Video Surveillance 8.5®). Os vídeos foram gravados em formato $\mathrm{gH} 264$, pelo software proprietário da Geovision.

O software da Geovision produz continuamente, para cada câmera, vídeos de cinco minutos. Caso haja algum problema na gravação de algum vídeo, a gravação é interrompida e uma nova se inicia imediatamente. O último vídeo do dia se interrompe às 00:00, independentemente da sua duração. Os vídeos foram todos salvos no próprio servidor, em um disco rígido separado do disco de sistema. O software de gravação já separa automaticamente os vídeos, salvando-os em um pasta por câmera, e uma subpasta por dia. Além disso, o software de gravação foi configurado para nomear cada vídeo segundo o número da respectiva câmera, data, hora, minuto e segundo de início, assegurando a confiabilidade das informações de origem e hora das gravações reduzindo a chance de enganos na utilização desses dados. Cada experimento possui em torno de 804 vídeos cujo armazenamento ocupa em disco em torno de cento e dez gigabytes. 
4. Contagens e validação 


\subsection{Objetivos específicos}

A fim de se obter o método mais adequado de contagem automatizada por software, três métodos diferentes foram validados por comparação com a contagem manual. Além disso, descreve-se a metodologia de paralelização do processamento por distribuição das análises em processos independentes, imprescindível para a análise do volume de dados coletados nos experimentos.

\subsection{Materiais e métodos}

\subsubsection{Análise dos vídeos}

Para a contagem do fluxo de formigas em cada um dos vídeos gravados foi desenvolvido um software específico de rastreamento e contagem. O software foi desenvolvido em C++ utilizando-se biblioteca OpenCV (BRADSKI, 2000), própria para a análise de imagens. Os métodos de rastreamento e contagem por vídeo são tipicamente divididos em duas etapas. A primeira é a detecção dos objetos a serem rastreados em cada quadro de um vídeo. A segunda é o rastreamento propriamente dito, em que um algoritmo busca relacionar os elementos detectados num quadro com os do quadro seguinte, estimando as trajetórias dos objetos rastreados. Esse tipo de problema é conhecido como rastreamento múltiplo (MTT: multiple target tracking) de número variável de elementos.

O primeiro método avalidao da análise consistiu, na primeira etapa, de uma modelagem estocástica dinâmica do fundo estático do vídeo ('background subtraction'), a partir do qual filtram-se os elementos que estão se movendo sobre este ('foreground'), utilizando-se o algoritmo ViBE (BARNICH; VAN DROOGENBROECK, 2011), de implementação própria. Na segunda etapa, esses elementos móveis, formigas no caso, são rastreados por múltiplos filtros Kalman simultâneos, gerenciados por uma camada lógica. À cada quadro do vídeo, a atribuição de dados de posição dos elementos móveis observados aos elementos já existentes é realizada segundo a estratégia de minimização da soma global das distâncias, através do algoritmo húngaro (também conhecido como Munkres), adaptado para matrizes retangulares (BOURGEOIS, FRANÇOIS; LASSALLE, 1971). Em sequência, a existência desses elementos rastreáveis identificados é condicionada à um teste sequencial de razão de probabilidade (LI; LI; JILKOV, 2002; WALD, 1945), permitindo 
que um elemento devidamente identificado seja criado ao acumular detecções consecutivas, ou deletado ao acumular não detecções consecutivas. Esse teste evita a detecção de falsos positivos, como ruídos que aparecem ocasionalmente num quadro e somem no seguinte, e evita também o encerramento prematuro de um rastreamento em função de uma formiga ter parado de se movimentar por algum período de tempo curto.

Além disso, o software cria uma linha de contagem transversal ao sentido de deslocamento de formigas na trilhas. A contagem é feita pela linha, que registra quantos rastreadores a cruzaram e em qual sentido. A contagem não é realizada imediatamente no momento do cruzamento da linha, mas quando aquele rastreador kalman é eliminado, ou seja, quando a formiga deixa o vídeo, ou o rastreador dela é perdido. Isso reduz muito a complexidade da contagem, eliminando muitos erros em função da perda de rastreadores devido à interação entre formigas e às inversões de sentido das formigas (meia-volta) que acabam cruzando a linha mais de uma vez. A estratégia de contagem por cruzamento da linha foi utilizada em todas as metodologias testadas.

$\mathrm{Na}$ segunda metodologia implementada e testada de contagem, manteve-se a detecção com o filtro de movimentos utilizando o ViBE e apenas a etapa de rastreamento foi substituída. Foi utilizado um algoritmo de rastreamento múltiplo, conhecido como RRANSAC (recursive random sample consensus)(NIEDFELDT; BEARD, 2014), também de implementação própria, em $\mathrm{C}++$, utilizando-se a biblioteca OpenCV. Este algoritmo opera segundo um outro paradigma mais moderno, o rastreamento pré detecção, sendo teoricamente mais robusto para casos de múltiplos objetos que podem interagir entre si. Nele, o problema de associação de dados é posto de forma que o número de fontes de sinal (formigas) é estimado conjuntamente com as trajetórias, permitindo associações mais flexíveis e promíscuas entre as observações e os rastreadores existentes, o que garantiria maior robustez. No entanto, a dificuldade de utilização desse algoritmo é a sua parametrização, pois apresenta muitos parâmetros a serem ajustados.

Por fim, pretendeu-se testar ainda um terceiro método. Neste, a etapa de detecção é realizada por um método de reconhecimento de padrões utilizando-se redes neurais de convolução (CNNs), conhecido como deep learning. O rastreamento subsequente poderia ser realizado por algum dos utilizados nas metodologias anteriores. Porém, devido a 
quantidade necessária de dados anotados manualmente para o treinamento ser muito grande e ainda requerer uma validação exclusiva para essa etapa, seus resultados foram somente avaliados visualmente, sem a utilização de uma metodologia adequada para a comparação.

Apesar da contagem ser automatizada, o processamento de um vídeo consome tempo próximo ao real. Além disso, ele analisa uma câmera por vez. Sendo assim, levaria dezesseis vezes mais tempo para analisar os vídeos do que a duração do experimento. Sem contar com o tempo de intervalo entre uma análise e outra, que seria iniciada somente com um novo comando. Para poder processar os vídeos mais rapidamente, foi desenvolvido um programa em Python para a distribuição das análises em múltiplos processos. Esse programa utiliza uma estratégia conhecida como semáforo, em que, no caso, organiza uma lista de vídeos a serem a analisados - lista de tarefas - e cria múltiplas instâncias de execução (a quantidade é um parâmetro definido pelo usuário). Essas instâncias puxam as tarefas da mesma lista compartilhada. Dessa forma não só o processamento é paralelizado, podendo-se inclusive fazer uso dos múltiplos núcleos de processamento das cpus modernas, mas garante-se que não haja tempo perdido na sincronização entre processos paralelos, pois a análise de cada vídeo é independente. Assim que uma instância termina uma tarefa, está livre para iniciar a próxima da lista sem ter que esperar outra instância terminar para que sincronizem. Usando-se o servidor anteriormente mencionado, a análise de cada experimento durou pelo menos quatro dias utilizando-se 4 instâncias de processos simultâneos.

Para cada vídeo, o software de contagem produz um arquivo de texto contendo os resultados. Neste, há o número do quadro e o sentido de cada evento de passagem de formiga pela linha de contagem. Conhecendo-se o horário de início de cada vídeo, do seguinte e a quantidade total de quadros, calcula-se o momento de cada evento de contagem e atribui-se a cada um deles um valor de dia, hora, minuto e segundo ('timestamp'). Foi produzido um conjunto de programas em Python para a leitura de todos esses arquivos de texto, geração dos 'timestamps' e organização dos dados num formato de banco de dados armazenados em formato binarizado (.npy) para fácil leitura e posterior análise dos resultados. 


\subsubsection{Validação das contagens}

Para a validação, foi feita uma comparação entre as contagens resultantes da análise dos vídeos dos experimentos pelo software desenvolvido e contagens manuais. Para esta comparação, foram selecionados aleatoriamente dois vídeos de cada uma das dezesseis câmeras de cada uma das cinco réplicas experimentais, totalizando 160 vídeos. Estes pares eram de um vídeo do primeiro e um do último dia, de cada câmera, de cada experimento. Dessa forma, há dois momentos bem diferentes de cada câmera a serem observados.

Foi realizada a contagem manual de cada um desses 160 vídeos, o que corresponde a 13 horas e 20 minutos. Na expectativa de se adotar os mesmos critérios de contagem para os dois métodos avaliados, na contagem manual foi também traçada uma linha de contagem sobre o vídeo, paralela à direção da trilha, contando-se somente as formigas que cruzavam essa linha. Para isso foi feito um programa de computador em Python, que exibe o vídeo quadro à quadro, com um contador para cada sentido, acionáveis pelo teclado, e que salva os resultados da contagem em arquivos de texto iguais aos da contagem automática. Para a comparação em si, foi realizada uma regressão linear entre as duas contagens.

Para as contagens com o algoritmo RRANSAC, diante do desafio do ajuste de parâmetros, optou-se por adotar uma estratégia de otimização de seus valores. Para tal, dividiu-se os vídeos aleatórios em um grupo de 40, utilizado para a otimização de parâmetros com base nos dados anotados (contagens manuais), e um grupo de 120, para a validação. Para a otimização foi utilizado o método de otimização bayesiana. Este método amostra o espaço paramétrico através de uma busca na forma de processo gaussiano. Ele é particularmente recomendado em problemas de otimização em que cada iteração (teste de um conjunto de valores) é muito custosa. Justamente como no caso em questão, em que a cada iteração todos os quarenta vídeos são analisados. A cada iteração, estimou-se o $\mathrm{R}^{2}$ da regressão linear entre contagem manual e a automática em cada sentido, utilizando-se como função objetiva (ou de custo) a ser otimizada a soma desses dois valores. 


\subsection{Resultados}

$\mathrm{Na}$ validação do primeiro método, foram comparados o número total de formigas contadas em cada sentido obtidos pelo método manual e pela análise automática para cada vídeo, não havendo distinção entre os eventos específicos das contagens, comparando-se somente os números finais em cada vídeo.

Figura 2 - Comparações entre as contagens automáticas e manuais em cada sentido.
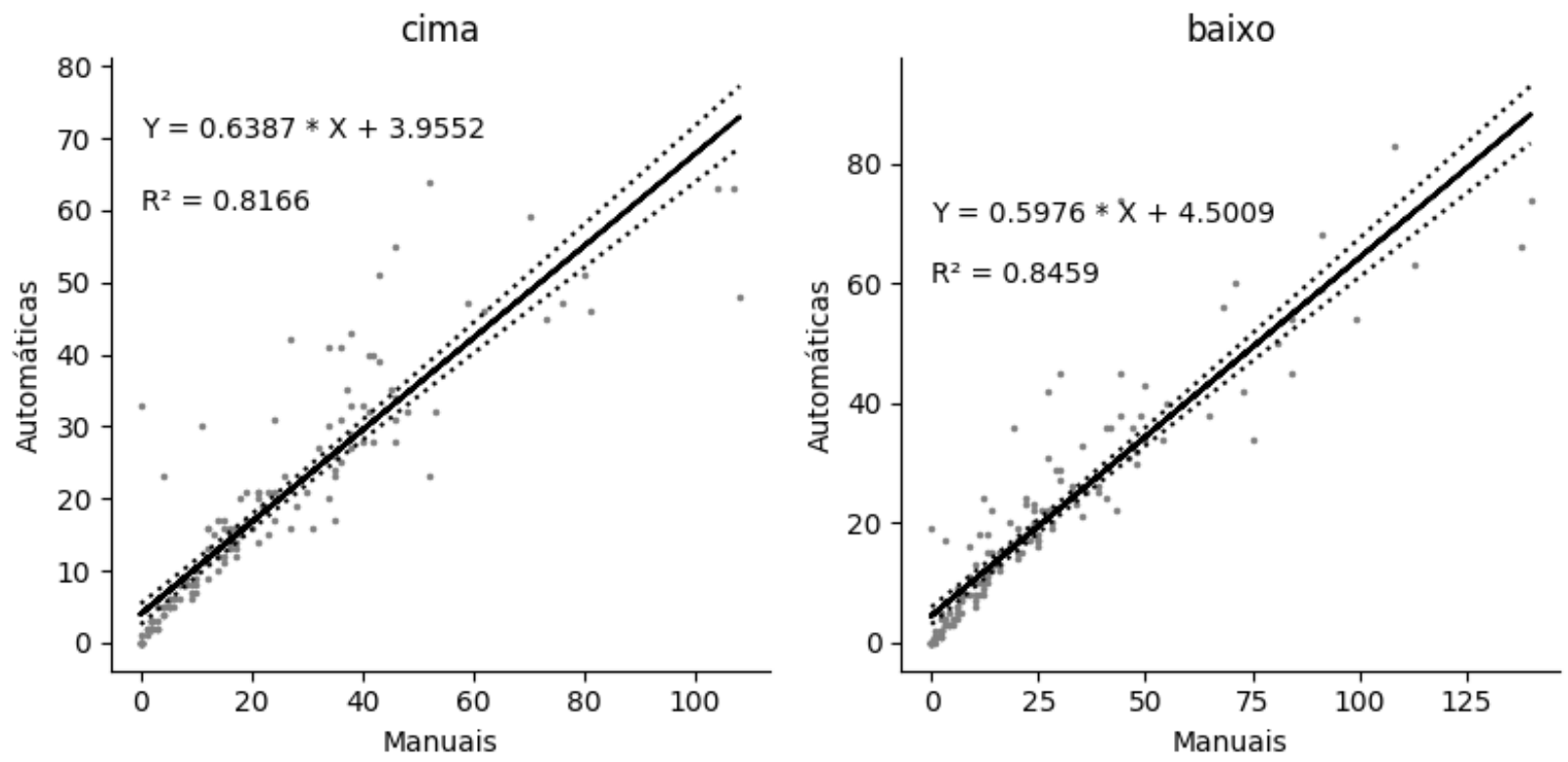

A figura 2 mostra que as contagens manuais apresentam uma dispersão razoavelmente grande em torno dos valores obtidos nas automáticas, reduzindo o valor do coeficiente de determinação. Apesar do ajuste entre as contagens manuais e automática não ser ideal e a dispersão acusar uma precisão não muito fiel, a acurácia não está ruim. Além disso, a comparação com usando regressão linear tende a não ser muito usada por conta, entre outros fatores, de penalizar demais o ajuste em função da presença de outliers e mais recentemente outras técnicas têm sido preferidas (Milan, et. al 2016.; Bernardim, 2008). No entanto, estas requerem que se anote manualmente todas as posições das formigas e não só a contagem total ao final do vídeo.

Nas contagens manuais, de início, foi possível descontar formigas que cruzavam a linha mais de uma vez (meia volta). No entanto, esse procedimento é impossível em 
momentos de grande fluxo. Mesmo passando o vídeo quadro a quadro, quando o fluxo é alto, torna-se muito complicado conseguir acompanhar cada indivíduo para saber se ele fez uma meia volta ou se é outro indivíduo a cruzar a linha de contagem. Além disso, vale lembrar que a contagem manual, especialmente nesses casos de muito fluxo, não é absolutamente correta, variando inclusive numa posterior recontagem. Levando-se em consideração todas as fontes de erros na contagem manual, esta é realizada meramente como referência na comparação com a automática, e não como o valor absoluto a ser objetivado por esta. Portanto, a contagem automática é testada como alternativa viável dada a quantidade de vídeos a serem analisados, e não como um método substitutivo de maior precisão, comparável à uma contagem ideal. Além disso, vale notar que o número de vídeos cujo fluxo se encontra na faixa de maior disparidade é bastante inferior ao restante, de forma que se por um lado, o erro é maior, por outro ele é muito menos frequente (figura 3).

Figura 3. Distribuição de frequências de videos de acordo com as suas contagens em cada sentido.
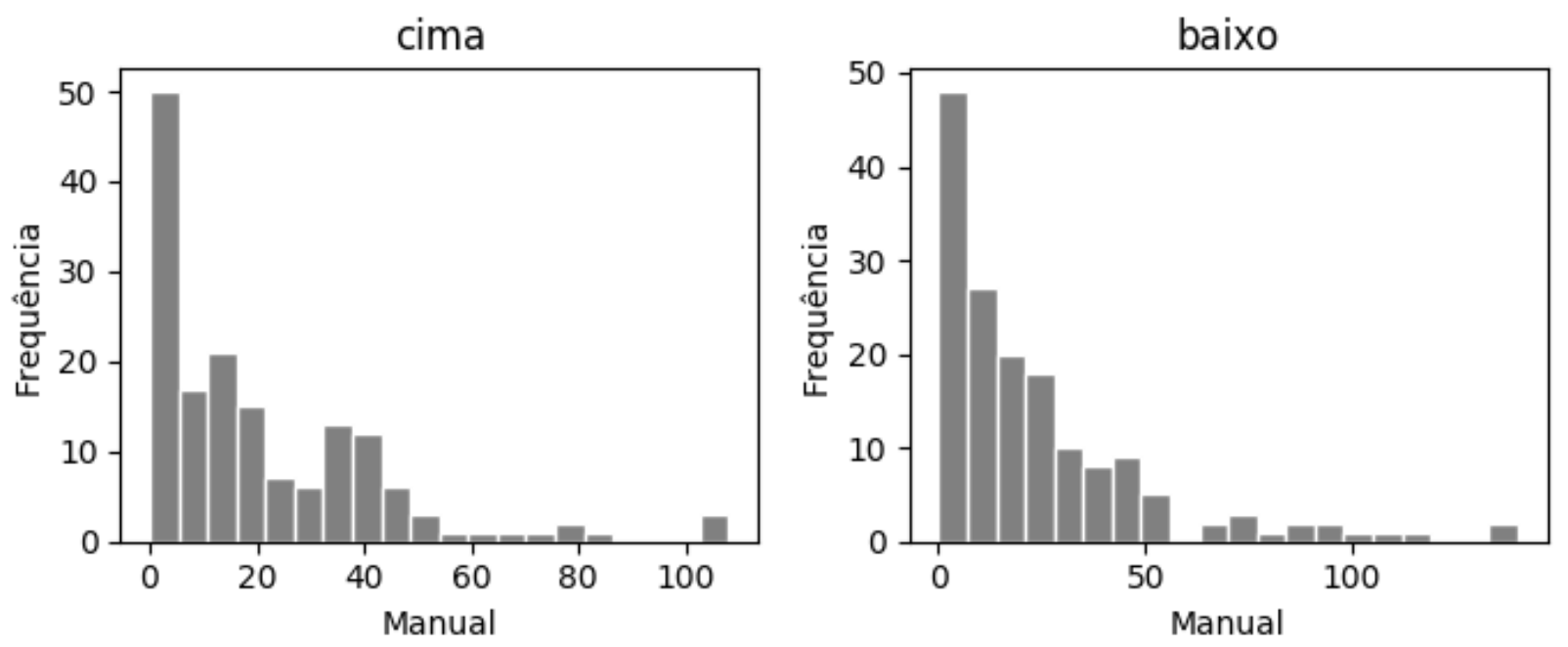

Quanto a validação com o algoritmo RRANSAC, infelizmente, o método descrito não produziu bons resultados. Por duas razões. Primeiramente, pela escolha da função objetiva como uma função de soma. Essa função é claramente monotônica, de forma que não há mínimos ou máximos a serem explorados, somente nos limites. O resultado obtido foi que o melhor conjunto de parâmetros produzia somente contagens num sentido, ignorando completamente as contagens no outro, de forma que o $\mathrm{R}^{2}$ de um sentido compensasse o erro do outro. O outro problema foi que, por desconhecimento de valores mais adequados, 
os limites do espaço paramétrico definido talvez tenham sido muito amplos. Tal que alguns conjuntos de valores de parâmetros testados eram tão espúrios a ponto de tornar os dados improcessáveis em tempo razoável. Como as contagens eram realizadas em paralelo, como sub processos simultâneos, foi possível observar que as análises de alguns vídeos tomavam tempo demais. Essas eram então canceladas manualmente. Além de criar a necessidade de supervisão do processo, esse sistema não penaliza a anulação exatamente de valores problemáticos, o que levaria à uma superestimativa do $\mathrm{R}^{2}$, inclusive podendo reforçar e direcionar a busca para as proximidades desses mesmos valores. Esse processo de otimização levou nove dias rondado em múltiplos processos paralelos num computador com 8 núcleos de processamento (core i7) com 32gb de memória RAM. Diante do desafio de criar um método de limite de tempo para gerenciamento dos subprocessos, substituição da função objetiva e método de punição para quando o limite de tempo era ultrapassado, optou-se por manter a metodologia de contagem com uso de múltiplos filtros Kalman associados através do algoritmo húngaro.

Quanto à terceira metodologia, com base na anotação manual de alguns vídeos foi possível treinar redes neurais profundas de RPN (region proposal networks) (YOLO2) (REDMON; FARHADI, 2016), disponíveis num framework chamado 'darknet' implementado em C. Apesar dos resultados obtidos, embora avaliados visualmente, serem muito promissores, o método depende de uma base muito grande de dados anotados manualmente (no caso é necessário selecionar quadros aleatórios com formigas presentes, e desenhar um retângulo ao redor de cada formiga para indicar sua posição para que a rede possa aprender a detectá-la). Apesar de todas as câmeras serem iguais, há diferenças no ajuste de foco durante a captura e da oscilação da luminosidade captada pelos sensores, de forma que algumas câmeras produzem vídeos substancialmente diferentes das outras. Um dos desafios particulares da utilização de CNNs é exatamente a generalização para cenários diferentes. Diante dessa situação, há duas possibilidades: treinar um modelo para cada câmera, ou treinar um modelo único com imagens provenientes de todas elas numa base com muitas imagens (em torno de 32 mil, pelo menos). Outro aspecto negativo desse método, no caso da utilização em rastreamento, é que se o detector não apresentar uma alta sensibilidade (razão entre verdadeiros positivos e verdadeiros positivos e negativos) a detecção pode sofrer uma alta intermitência. Como uma boa parte dos algoritmos de rastreamento (inclusive o RRANSAC) foi desenvolvido sob o paradigma da detecção por filtro de movimento (que tem alta sensibilidade, embora uma 
precisão menor), a intermitência advinda de uma CNN não muito sensível pode introduzir maiores dificuldades para o algoritmo de rastreamento subsequente.

\subsection{Conclusões}

Foram analisadas cinco réplicas experimentais, cada uma com dezesseis câmeras e duração de 67 horas. No total, foram analisados 64320 vídeos de cinco minutos cada, correspondendo à 5360 horas, ao longo das quais foram contadas 2294303 passagens de formigas pelas trilhas. O desenvolvimento do software de análise dos vídeos para a automatização das contagens foi essencial para a realização do experimento. Sendo assim, frente à possibilidade de realização do experimento, a qualidade atual das contagens é razoável o suficiente para a observação dos comportamentos de fluxo no labirinto. Ainda há possibilidade de melhorias na qualidade das contagens à medida que, conforme observado realizando-se a comparação com a contagem manual, há erros principalmente em casos de maior fluxo. Uma vez que os erros principais são diagnosticados na validação pode ser mais fácil encontrar formas de corrigí-los.

Quanto à forma de avaliação da qualidade das contagens, a regressão linear, apesar de ser extremamente prática, é muito sensível aos outliers na extremidade superior dos valores observados. Tal sensibilidade desajusta a estimação entre valores intermediários e inferiores, comprometendo demasiadamente o coeficiente de determinação $\left(R^{2}\right)$, de forma que a baixa precisão comprometa inclusive a acurácia. Além disso não leva em conta o fato de que, no caso, somente uma pequena minoria dos vídeos se encontra nas proximidades dos valores de contagens mais comprometidos.

Outras técnicas de análise dos vídeos para a realização das contagens automáticas de formigas foram testadas. Um algoritmo diferente de rastreamento (Recursive RANSAC), e um método diferente de detecção (CNN). Entretanto cada um apresentou uma barreira técnica diferente. O primeiro é bastante dependente de uma parametrização adequada para a obtenção de bons resultados. Além de serem muitos parâmetros a serem ajustados, a realização do ajuste manual com inspecção visual não é muito eficaz porque em situações de fluxo muito distintas o ajuste de um caso pode comprometer o do outro. Para que o ajuste fosse válido em mais casos, utilizou-se uma técnica de otimização. Entretanto, a automatização do ajuste trouxe complicações particulares, como a escolha da função de 
custo e a delimitação adequada do espaço paramétrico, de forma que embora tenha sido concluída,não foi capaz de encontrar valores de parâmetros que garantissem uma boa qualidade nas contagens. Já a CNN, por conta de depender de uma grande quantidade de dados manualmente anotados, exige o desenvolvimento de um número grande de programas acessórios. Desde programas para selecionar os quadros dos vídeos a serem utilizados até programas com interfaces gráficas para a anotação manual. Além disso, diante do resultado preliminar obtido de não generalização entre câmeras diferentes, seria necessário treinar um número grande de modelos diferentes.

Houve uma grande necessidade de desenvolvimento de ferramentas para lidar com desafios como a grande quantidade de arquivos e a contagem manual. Dentre esses vale destacar o desenvolvimento de ferramentas de paralelização do processamento. Para o volume de dados produzidos pelos experimentos (em torno de $110 \mathrm{~Gb}$ de vídeos por experimento, comprimidos) é inviável trabalhar sem a distribuição múltipla dos processos, paralelizando as análises. De outra forma, o tempo necessário é demasiadamente prolongado, inviabilizando completamente a realização das análises, comprometendo os experimentos. 
5. Modelos e simulações 


\subsection{Objetivos específicos}

Uma vez que o experimento realizado tem por objetivo estabelecer uma correspondência entre as dispersões observadas em cada caso e os comportamentos de forrageamento e exploração, foram desenvolvidos modelos para construção de cenários exclusivos para cada um desses comportamentos em que o modo de funcionamento desses é conhecido e determinado.

O modelo nulo tem por objetivo produzir dispersões espaço temporais de formigas no labirinto segundo um modelo uniforme de probabilidades na decisão de trilhas a serem percorridas diante das bifurcações. Já o modelo de forrageamento busca fornecer um cenário em que todas as formigas estão envolvidas na formação de uma trilha preferencial interagindo através da marcação com feromônios voláteis.

O objetivo dos modelos não é o de que estes sejam explicações funcionais para os comportamentos observados. Pelo contrário, eles viabilizam a construção de cenários específicos, em que se possa observar as dispersões produzidas por regras de funcionamento pré estabelecidas operando na estrutura particular do labirinto. Portanto eles não tem o objetivo de explicar ou replicar os dados observados, mas de servirem de contrastes, de forma que se possa balizar os resultados obtidos nos experimentos e controles em função dos resultados das simulações.

\subsection{Materiais e métodos}

\subsubsection{Modelo nulo}

A fim de se observar o que seria um caso puramente de exploração, sem marcação feromonal ou outra forma de interação entre os indivíduos e que fosse aleatória de distribuição uniforme, foi criado um modelo computacional para simular como seria esse processo, uma vez que é pouco difícil construir hipóteses sobre o que aconteceria em razão da estrutura bastante particular do labirinto utilizado. Além disso, a simulação fornece a vantagem de se poder avaliar a dinâmica do processo exploratório. 
Há duas dificuldades importantes na parametrização dos modelos de simulação. A primeira delas é em relação ao tempo de duração. Por um lado, poderia-se utilizar o tempo total de duração (67 horas) de cada experimento. Entretanto, deveria-se conhecer ou estimar o intervalo médio com que as formigas se movimentam entre caixas e a velocidade média de deslocamento, bem como as variâncias dessas medidas. Por outro lado, cada contagem observada no experimento corresponde exatamente à uma formiga se deslocando de uma dada caixa para outra, de forma que o número total de movimentos observados corresponde à totalidade de duração do experimento. Dessa forma pode-se dizer, por exemplo, que o experimento controle 1 durou 67 horas, ou 373290 movimentos. Alternativamente a utilização do tempo decorrido, a duração do modelo foi parametrizada pelo número de movimentos observados.

Outra dificuldade na parametrização do modelo é saber o número de formigas a ser utilizado na simulação. Afinal, no experimento não se sabe em momento nenhum o número de formigas presentes no labirinto. Para isso observou-se no experimento controle expc1 os eventos de contagem nas trilhas 10 e 13 no sentido da caixa central para as respectivas caixas adjacentes. Esse movimento corresponde à formigas saindo da colônia e entrando no labirinto. Calculou-se a cada intervalo de trinta minutos a razão entre o número desses eventos e a quantidade total de movimentos observados. Assim, foi possível estimar qual a probabilidade de entrada de formigas no labirinto ao longo do experimento, ou ainda, ao longo da quantidade de movimentos até um dado momento.

No modelo, à cada iteração (tempo discreto), sorteia-se um movimento. Quando o movimento sorteado é de entrada, é então sorteado se a entrada será pela trilha 10 ou 13 com probabilidade 0.5 para cada lado. Quanto é sorteada a movimentação de uma formiga já existente, sorteia-se qual a formiga, aleatoriamente com probabilidade uniforme. Dada a posição (caixa) em que essa formiga sorteada está, sorteia-se também com probabilidade uniforme uma das caixas conectadas à sua posição atual, e então move-se a formiga sorteada ao destino sorteado. A cada movimento registra-se a contagem de fluxo na trilha de conexão entre as caixas envolvidas. $\mathrm{Na}$ ocorrência de uma formiga aleatoriamente retornar à caixa central, esta é deletada da lista de formigas, pois seu movimento subsequente seria correspondente à uma nova entrada. 


\subsubsection{Modelo de forrageamento}

Quanto à duração e ao número de formigas, o modelo de forrageamento funciona da mesma forma que o modelo nulo. A cada iteração é sortedao se uma nova formiga entra no labirinto ou se move-se uma já existente. Ainda como o modelo nulo, no caso de movimentar uma já existente, sorteia-se aleatoriamente com probabilidade uniforme qual a formiga a ser movida. Quanto a esses aspectos, a única diferença é que a estimativa de probabilidade de entrada de novas formigas e a duração foram estimadas com base no experimento com folhas exp2.

As diferenças em relação ao modelo nulo estão em como são realizadas as movimentações de formigas já existentes no labirinto. Neste aspecto, o modelo de forrageamento é igual ao Ant System (DORIGO; DI CARO, 1999; DORIGO; MANIEZZO; COLORNI, 1996; DORIGO; STÜTZLE, 2004), com uma pequena alteração que será apresentada posteriormente.

Começando pelo comportamento de retorno, quando um indivíduo chega à fonte de alimento, ele deve retornar à colônia. Entretanto, o seu comportamento de retorno, diferentemente da ida, é determinístico. Ele volta pelo caminho oposto ao que fez na ida. Entretanto, são removidos os laços desse caminho de volta. Laço é o trecho de caminho compreendido em uma repetição de alguma trilha. Ou seja, para se determinar o caminho de volta inverte-se o caminho de ida, são retiradas todos os trechos cíclicos do caminho e, então, ele é percorrido de forma determinística. À cada trilha desse retorno, a formiga em questão deposita feromônios para marcá-la de acordo com a seguinte fórmula:

$$
\Delta \tau_{(i, j)}^{k}=\left\{\begin{array}{cl}
Q / L_{k} & \text { se a formiga k usar a trilha }(i, j) \\
0 & \text { se não }
\end{array}\right.
$$

Em que $k$ é a formiga em questão; $(i, j)$ é a trilha que conecta as caixas $i$ e $j ; \tau_{(\mathrm{i}, j)}$ é a quantidade de feromônio na trilha (i,j); Q é uma constante; $L_{k}$ é o comprimento do caminho de retorno da formiga $k$.

Para as formigas que ainda não chegaram a fonte de alimento, a cada etapa sorteiase qual o seu próximo movimento de acordo com as seguintes probabilidades: 


$$
p_{(i, j)}^{k}=\left\{\begin{array}{cl}
\frac{\tau_{(i, j)}^{\alpha} \cdot \eta_{(i, j)}^{\beta}}{\sum c_{(i, j)} \in N\left(s^{p}\right) \tau_{(i, j)}^{\alpha} \cdot \eta_{(i, j)}^{\beta}} & \text { se } c_{(i, j)} \in N\left(s^{p}\right) \\
0 & \text { se não }
\end{array}\right.
$$

Em que $\mathrm{N}\left(\mathrm{s}^{p}\right)$ é o conjunto de trilhas adjacentes, e portanto acessíveis a partir da posição atual da formiga $\mathrm{k}$; $\alpha$ e $\beta$ são parâmetros fixos, ajustados a priori. A equação indica que a probabilidade de se seguir por uma trilha é dada como um balanço da quantidade de feromônio e distância normalizado para cada uma das possíveis trilhas adjacentes. O termo $\eta$ é o inverso da distância entre as caixas indicadas:

$$
\eta_{(i, j)}=\frac{1}{d_{(i, j)}} \text { em que d é a distância entre i e j }
$$

No modelo utilizado há uma diferença em relação ao Ant System, pois enquanto nele as possibilidades de trilhas adjacentes é ainda restringida para somente aquelas que a formiga k ainda não passou, no modelo em questão não há essa restrição, e as trilhas possíveis são todas as graficamente possíveis. Essa alteração foi necessária pois essa restrição no Ant System é particularmente vantajosa para o problema específico do caixeiro viajante, uma das aplicações mais utilizadas para a demonstração da capacidade de heurísticas de otimização. Na versão canônica deste problema, todos os nós são conectados entre si. Já no experimento em questão, como há somente bifurcações, a aplicação dessa restrição eliminaria a execução de caminhos cíclicos, o que não seria uma premissa razoável.

Além do já descrito, à cada iteração os feromônios presentes em todas as trilhas decaem (volatilizam) segundo uma taxa (rho). O decaimento é simultâneo à marcação no caso das trilhas que são reforçadas pela passagem de formigas retornando ao ninho:

$$
\tau_{(i, j)} \leftarrow(1-\rho) \cdot \tau_{(i, j)}^{k}+\sum_{k=1}^{m} \Delta \tau_{(i, j)}^{k}
$$




\subsection{Resultados}

\subsubsection{Modelo nulo}

Foram observados no experimento controle os eventos de contagem obtidos nas trilhas 10 e 13 no sentido de saída da colônia a fim de se avaliar o número de formigas entrando no labirinto ao longo do tempo. Observou-se a razão entre a quantidade destes eventos de contagem e o total de contagens em intervalos de 30 minutos. Foi utilizada uma regressão exponencial para descrever a curva observada. A função obtida empiricamente foi utilizada a cada iteração da simulação para se sortear se o movimento a ser realizado seria o de entrada de uma nova formiga, ou movimentação de uma já existente.

Figura 4. Ajuste da função de probabilidade de entrada de formigas no modelo nulo.
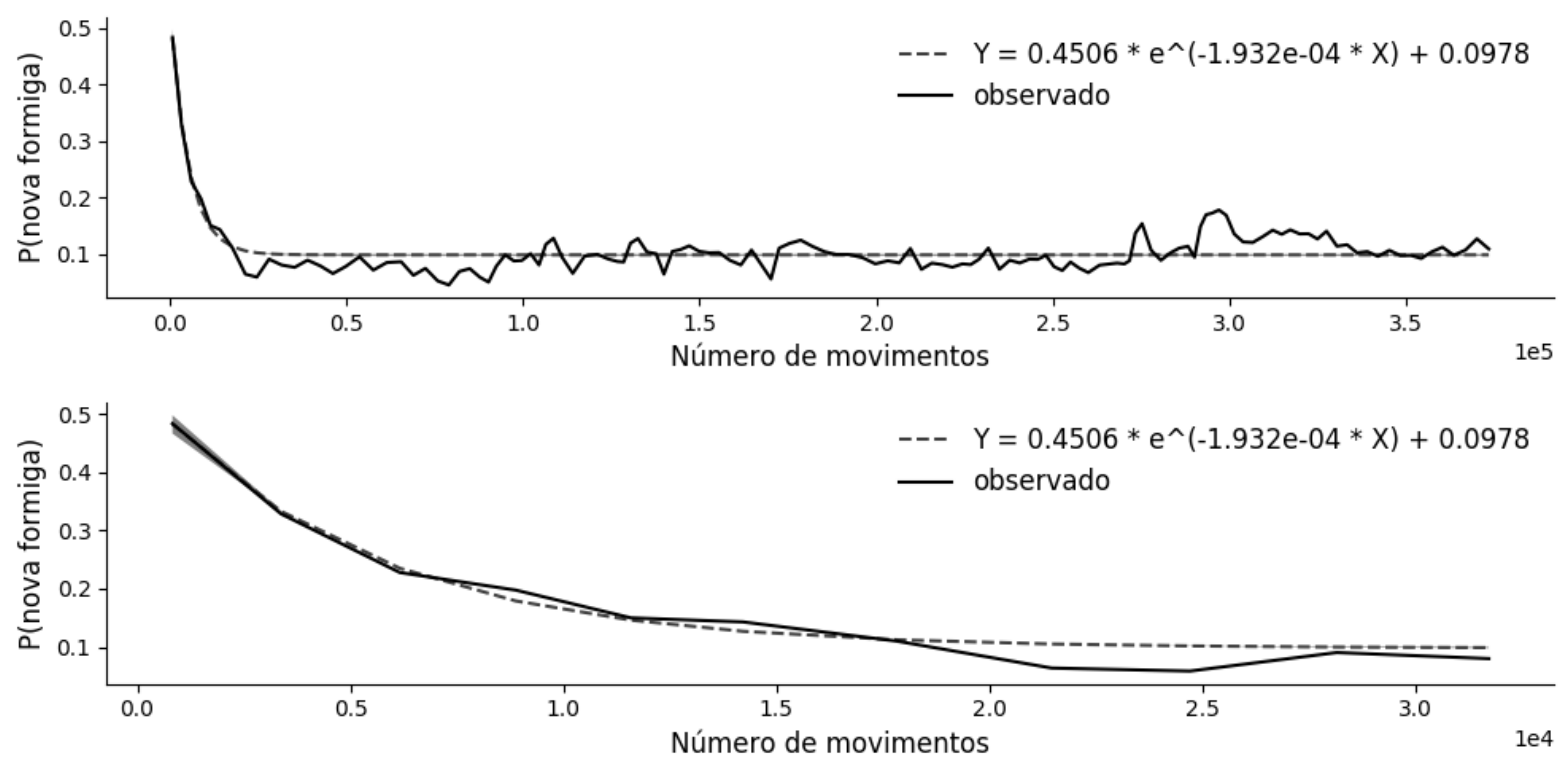

Os gráficos mostram a proporção de movimentos de saída pelas trilhas 10 e 13 em razão à quantidade total de movimentos ao longo do experimento. O grafico debaixo destaca os primeiros trinta mil movimentos.

Desse modeo é possível não só ajustar um modelo estocástico de simulação do comportamento exploratório no labirinto, reproduzindo a taxa de saída do ninho observada experimentalmente, mas também, uma vez que se determinou o total de iterações como a observada experimentalmente, é possível usar a simulação para estimar o número total de indivíduos dispersos pelo labirinto num dado momento. Utilizando a função acima e iterando o modelo por 373290 movimentos, ambos obtidos utilizando-se os dados do experimento controle expc1, o número de formigas no labirinto estabiliza próximo aos dois mil e quinhentos indivíduos. 


\subsubsection{Modelo de forrageamento}

Utilizou-se os mesmos procedimentos descritos acima para o modelo nulo, só que utilizando os dados do experimento 2. Uma vez determinado o número de movimentos e a função de probabilidade de entrada de novas formigas no labirinto, a etapa seguinte foi ajustar os parâmetros (alpha, beta, Q, rho). Há valores indicados na bibliografia, mas, devido às alterações principalmente em relação à parametrização pelo número de movimentos, os valores tiveram que ser novamente estimados. No modelo original, geralmente o número de formigas é fixo e se atualiza o feromônio das trilhas após se mover todas as formigas. Já nesta simulação, sorteia-se um indivíduo e em seguida se atualizam as trilhas, de forma que o valor de decaimento originalmente proposto seria muito grande. Tão maior quanto o número de formigas presentes.

Figura 5. Ajuste da função de probabilidade de entrada de formigas no modelo de forrageamento.
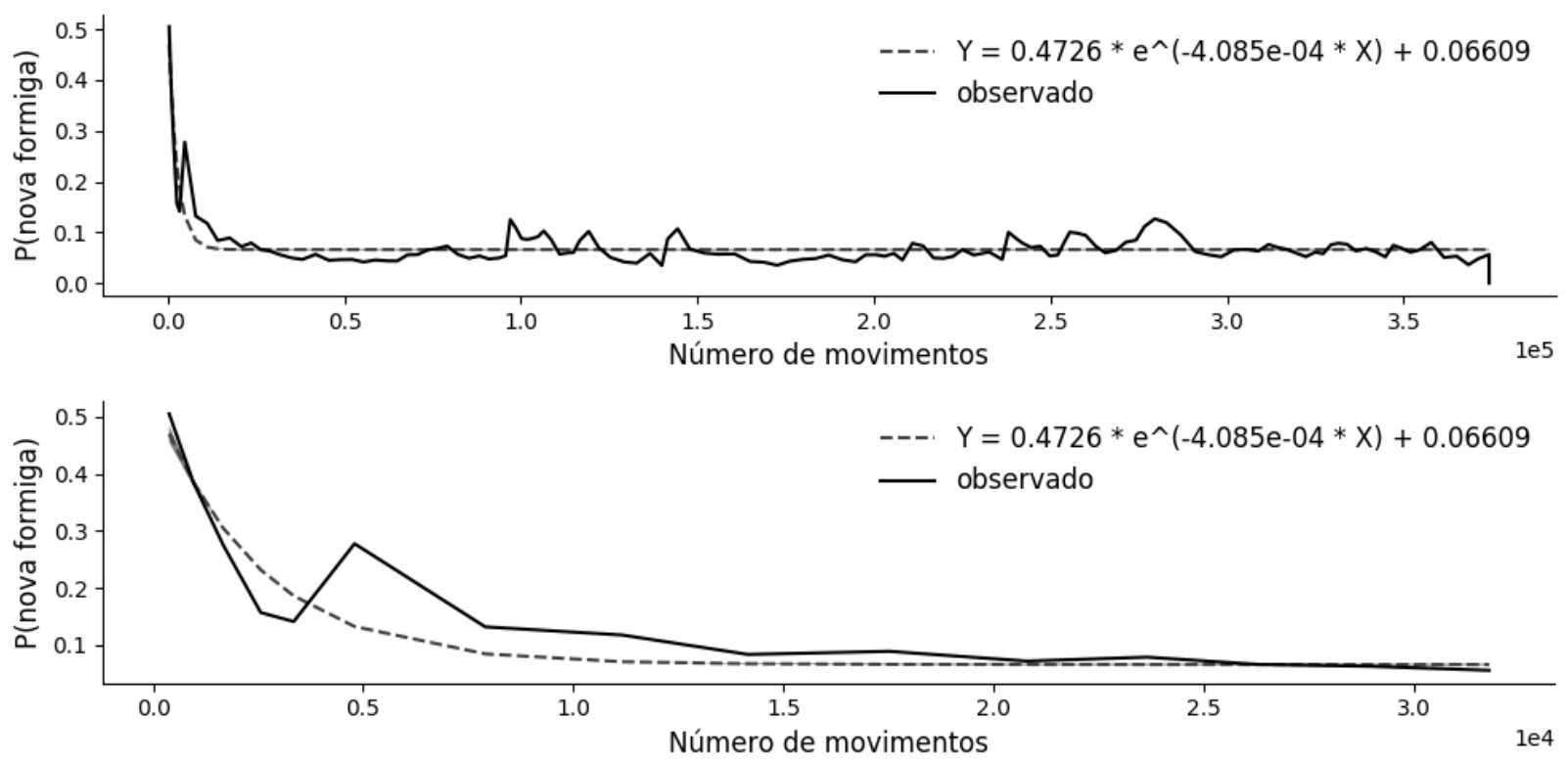

Os gráficos mostram a proporção de movimentos de saída pelas trilhas 10 e 13 em razão à quantidade total de movimentos ao longo do experimento. O grafico debaixo destaca os primeiros trinta mil movimentos.

Para se estimar novos valores de parâmetros, foi utilizado o mesmo método de otimização bayesiana citado na seção de análise dos vídeos. Esse é um método iterativo, e a cada iteração se testa um conjunto de parâmetros e avalia-se o resultado de acordo com alguma função objetiva (ou de custo). De acordo com o valor observado propõem-se um novo conjunto de valores a fim de se maximizar o resultado observado. Como o modelo é 
estocástico, um mesmo conjunto de valores pode produzir resultados diferente. Portanto, a cada iteração a simulação foi realizada quatro vezes. Ao final de cada uma delas, observouse a probabilidade de uso dos dois caminhos mínimos (trilhas: $[13,1,4,8,9]$ e trilhas: $[10,11,7,16,12])$ e selecionou-se a maior das duas. Dessa forma, estimou-se a formação de uma trilha preferencial mínima. Exatamente porque a proposta do modelo é convergir para uma das trilhas mínimas. Como resultado da função de custo utilizou-se então a mediana desses quatro valores. Foram realizadas duzentas iterações, sendo que as cinquenta primeiras foram ajustadas para uma busca mais ampla do espaço paramétrico (kappa = 10), as cinquenta subsequentes para um valor intermediário (kappa $=5$ ) e as cem finais para um valor mais baixo (kappa <=1). Ao final do processo, os valores obtidos correspondentes à maior convergência observada foram: $\mathrm{Q}=72$, alpha $=2.46$, beta $=2.08$, rho: 0.02 .

\subsection{Conclusões}

A parametrização da duração das simulações pelo número de movimentos foi suficiente para garantir a estabilidade da quantidade de formigas nas simulações. Graças à simplicidade do modelo nulo, esse é o único ponto que carece de algum ajuste. No modelo de forrageamento foram realizadas modificações a fim de torná-lo mais compatível com o problema em questão. Em consequência, foi necessário estimar novos valores de parâmetros utilizando o método de otimização bayesiana. Apesar do número de parâmetros, não foi necessário testar mais do que duzentas combinações diferentes de valores.

Ambos os modelos produziram simulações com características como duração, dispersão e número de contagens em cada trilhas compatíveis com os experimentos no sentido de poderem ser analisados conjuntamente para a que os dados experimentalmente observados possam ter como referência os resultados de processos conhecidos, conforme estabelecidos nos modelos. 
6. Análise dos caminhos de forrageamento 


\subsection{Objetivos específicos}

O objetivo desta análise é avaliar de que forma a dispersão observada nos experimentos corresponderia à formação de trilhas de forrageamento. Para isso estimou-se as probabilidades de todos os possíveis caminhos de ida e volta até o alimento e buscou-se avaliar quanto os caminhos são compatíveis com as dispersões experimentais observadas. A hipótese nula é de que os controles estejam mais próximos do modelo nulo do que os experimentos com folhas, apresentando menor otimização de caminhos e menor convergência para os caminhos preferenciais.

\subsection{Materiais e métodos}

Para comparar os experimentos segundo as probabilidades de uso de cada cada caminho foi utilizada uma metodologia baseada na proposta em (VITTORI et al., 2006) e (GARNIER et al., 2009). Dada a estrutura do labirinto, o posicionamento central da colônia e do oferecimento das folhas para forrageamento na caixa de alimentação, há dezesseis caminhos não cíclicos diferentes conectando a colônia às folhas. Uma vez que as contagens de fluxo nas trilhas identificam o sentido da passagem da formiga, o sentido também é levado em conta na especificação dos caminhos. Dessa forma, o labirinto pode ser considerado um grafo direcional em que cada trilha é composta por duas arestas paralelas, uma em cada sentido. Por caminho não cíclico entende-se uma sequência ordenada de trilhas que conecte as duas caixas (central e de alimentação), sem que haja repetição de uma mesma trilha num mesmo sentido.

caminho $c=\left[\left(t_{0}, s_{0}\right),\left(t_{1}, s_{1}\right), \ldots,\left(t_{n}, s_{n}\right)\right]$

em que:

- $\mathrm{t} \in$ trilhas $\{1,2, \ldots, 16\}$

- $s \in \operatorname{sentidos}\{1$ : horário, -1 : anti horário $\}$,

- $\left(t_{x}, s_{x}\right)$ é adjacente à $\left(t_{x+1}, s_{x}+1\right)$,

- $\left(t_{0}, s_{0}\right)$ é a colonia, $\left(t_{n}, s_{n}\right)$ tem destino na caixa das folhas,

- $\left(\mathrm{t}_{\mathrm{x}}, \mathrm{s}_{\mathrm{x}}\right) \neq\left(\mathrm{t}_{\mathrm{y}}, \mathrm{s}_{\mathrm{y}}\right) \forall \mathrm{x} \neq \mathrm{y}$ 
Utilizando-se um algoritmo de buscas de caminhos não cíclicos em grafos direcionais é possível obter todos os dezesseis diferentes caminhos entre as caixas da colônia e as folhas, bem como os dezesseis caminhos de volta (listados adiante). Esses caminhos são de diferentes comprimentos. Comprimento é, neste caso, entendido como o número de trilhas compreendidos num caminho. Há somente dois caminhos mínimos, simétricos, com cinco trilhas de comprimento. Os outros caminhos, mais compridos, compreendem sete, nove ou onze trilhas e também são pares bilateralmente simétricos.

comprimentode um caminhoc: $|c|=n$

Ao longo de cada caminho há bifurcações, dadas segundo a estrutura do labirinto. Por exemplo, partindo-se da caixa 1, a primeira bifurcação é entre a saída pelas trilhas 13 ou 10. Assumindo-se um caminho que parta pela trilha 10, em seguida há uma bifurcação entre as trilhas 15 e 11. Seguindo por esta última há mais uma entre as trilhas 3 e 7 e seguindo pela 7 há mais uma entre as trilhas 6 e 16. A partir da 16 não há mais nenhuma bifurcação até a caixa das folhas. Admitindo-se que as trilhas e sentidos sejam independentes, pode-se estabelecer um modelo nulo em que a probabilidade de se seguir por cada trilha de uma bifurcação seja $P=0.5$. Alternativamente, trilhas que não levem à bifurcação teriam uma probabilidade $P=1$. Sendo assim, para cada um dos caminhos não cíclicos é possível calcular uma probabilidade dada pelo produtório das probabilidade de suas partes integrantes. Além disso, é possível calcular também a probabilidade total dos caminhos cíclicos como o valor resultante de 1 (todos os caminhos possíveis) subtraído da somatória das probabilidades dos caminhos não cíclicos. Vale notar que a probabilidade de um caminho corresponde à probabilidade de que, dado que uma formiga foi da caixa central à caixa com folhas, ela o tenha feito por aquele caminho.

$$
\begin{gathered}
P(c)=\prod_{x=0}^{n} P\left(t_{x}, s_{x}\right) \\
P(\text { cíclicos })=1-\sum_{c \in C} P(c) \text {, em que } C=\left\{c_{1,}, c_{1}, \ldots, c_{16}\right\} \text { é o conjunto de caminhos acíclicos }
\end{gathered}
$$

Exemplo de caminho de volta com bifurcações: 


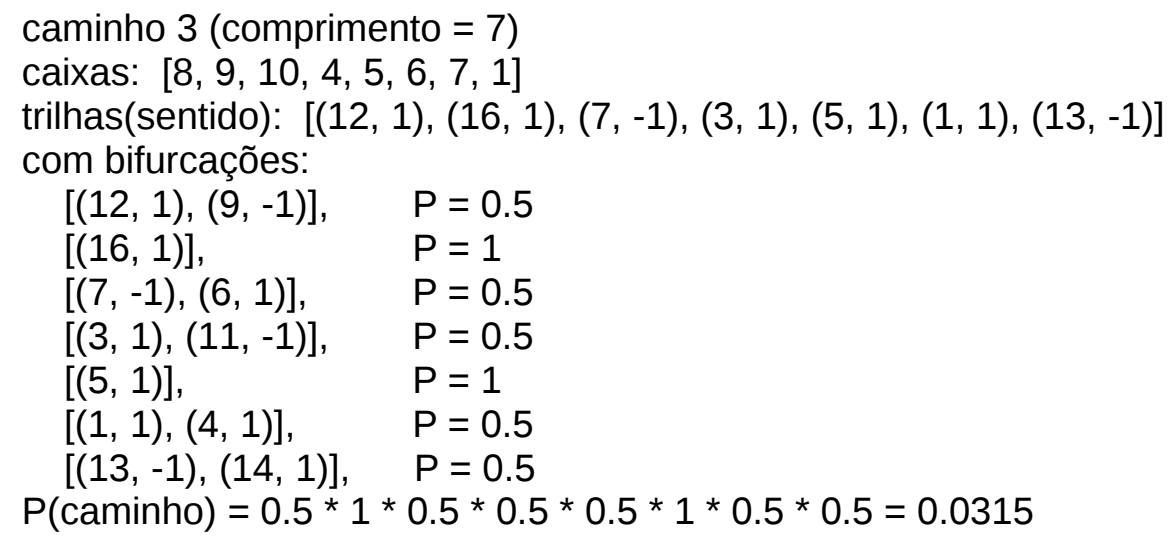

Foram calculadas também as probabilidades dos caminhos segundo os fluxos observados em cada experimento. Uma vez que se conhece o número de formigas em cada trilha é possível calcular a probabilidade das bifurcações para cada uma delas. Obtidas essas probabilidades pode-se multiplicá-las e calcular as probabilidades de cada caminho em cada experimento.

Em cada caso, seja no modelo nulo ou nas probabilidades obtidas segundo os fluxos de um experimento, somando as probabilidades dos caminhos de igual comprimento obtémse a probabilidade total de um dado comprimento $\mathrm{L}$.

$$
P(L)=\sum_{c \in C|| c \mid=L} P(c)
$$

Além das distribuições de probabilidades dos caminhos segundo seus comprimento, foram calculadas algumas medidas para auxiliar a interpretação dos resultados. Utilizando a divergência de Kullback Leibler foram comparadas as distribuições experimentais e 0 modelo nulo entre os caminhos agrupados ( $\mathrm{KL}$ comp.) pelo comprimento e não agrupados $(\mathrm{KL} P(\mathrm{c})$ ). Foram identificados os caminhos acíclicos de maior probabilidade de cada experimento (max. ) e sua probabilidade (Pmax.), a razão entre esta probabilidade no experimento e a do mesmo caminho no modelo nulo (razão (uni.)) e a convergência ao caminho de maior probabilidade (conv.). A fim de se observar a formação de caminhos preferenciais, avaliou-se em cada experimento o caminho lateralmente simétrico ao de 
maior probabilidade. Calculou-se a razão entre a probabilidade do caminho de maior probabilidade e o seu simétrico (lateralidade).

Através das simulações do modelo nulo foram obtidas as distribuições das medidas de divergência de Kullback Leibler, para as convergências e para as razões entre a probabilidade observada e a esperada (razão uni.). Uma vez obtidas estas distribuições, foi possível avaliar se as diferenças entre os valores obtidos nos experimentos diferiram significativamente do modelo nulo utilizando o método de Monte Carlo.

\subsection{Resultados}

O labirinto possui 16 caminhos não cíclicos de ida da caixa central à caixa das folhas, e 16 de volta. Os caminhos não cíclicos e as respectivas probabilidades calculadas segundo o modelo nulo seguem listadas abaixo:

Idas:

$[13,1,4,8,9](5) \mathrm{P}=0.062500$

$[10,11,7,16,12](5) P=0.062500$

$[13,1,5,3,7,16,12](7) P=0.031250$

$[13,1,4,2,6,16,12](7) P=0.031250$

$[13,14,15,11,7,16,12](7) P=0.031250$

$[10,15,14,1,4,8,9](7) P=0.031250$

$[10,11,3,5,4,8,9](7) P=0.031250$

$[10,11,7,6,2,8,9](7) P=0.031250$

$[13,1,5,3,7,6,2,8,9](9) P=0.015625$

$[13,14,15,11,3,5,4,8,9](9) P=0.015625$

$[13,14,15,11,7,6,2,8,9](9) P=0.015625$

$[10,15,14,1,5,3,7,16,12](9) \mathrm{P}=0.015625$

$[10,15,14,1,4,2,6,16,12](9) \mathrm{P}=0.015625$

$[10,11,3,5,4,2,6,16,12](9) P=0.015625$

$[13,14,15,11,3,5,4,2,6,16,12](11) P=0.007812$

$[10,15,14,1,5,3,7,6,2,8,9](11) P=0.007812$

Voltas:

$[9,8,4,1,13](5) \mathrm{P}=0.062500$

$[12,16,7,11,10](5) \mathrm{P}=0.062500$

$[9,8,2,6,7,11,10](7) \mathrm{P}=0.031250$

$[9,8,4,5,3,11,10](7) \mathrm{P}=0.031250$

$[9,8,4,1,14,15,10](7) P=0.031250$

$[12,16,6,2,4,1,13](7) \mathrm{P}=0.031250$ 
$[12,16,7,11,15,14,13](7) \mathrm{P}=0.031250$

$[12,16,7,3,5,1,13](7) P=0.031250$

$[9,8,2,6,7,11,15,14,13](9) \mathrm{P}=0.015625$

$[9,8,2,6,7,3,5,1,13](9) \mathrm{P}=0.015625$

$[9,8,4,5,3,11,15,14,13](9) P=0.015625$

$[12,16,6,2,4,5,3,11,10](9) \mathrm{P}=0.015625$

$[12,16,6,2,4,1,14,15,10](9) \mathrm{P}=0.015625$

$[12,16,7,3,5,1,14,15,10](9) P=0.015625$

$[9,8,2,6,7,3,5,1,14,15,10](11) \mathrm{P}=0.007812$

$[12,16,6,2,4,5,3,11,15,14,13](11) \mathrm{P}=0.007812$

Pode-se observar que cada um dos caminhos mais curtos são individualmente mais prováveis que os mais longos. Isso se deve ao fato de que, por serem menores, possuem menos bifurcações. As simetrias entre ida e volta e a simetria bilateral se expressam também nas probabilidades.

Foram calculadas também as probabilidades de cada caminho utilizando-se os dados observados em cada um dos experimentos. Exemplo de cálculo de probabilidade de caminho para o exp2:

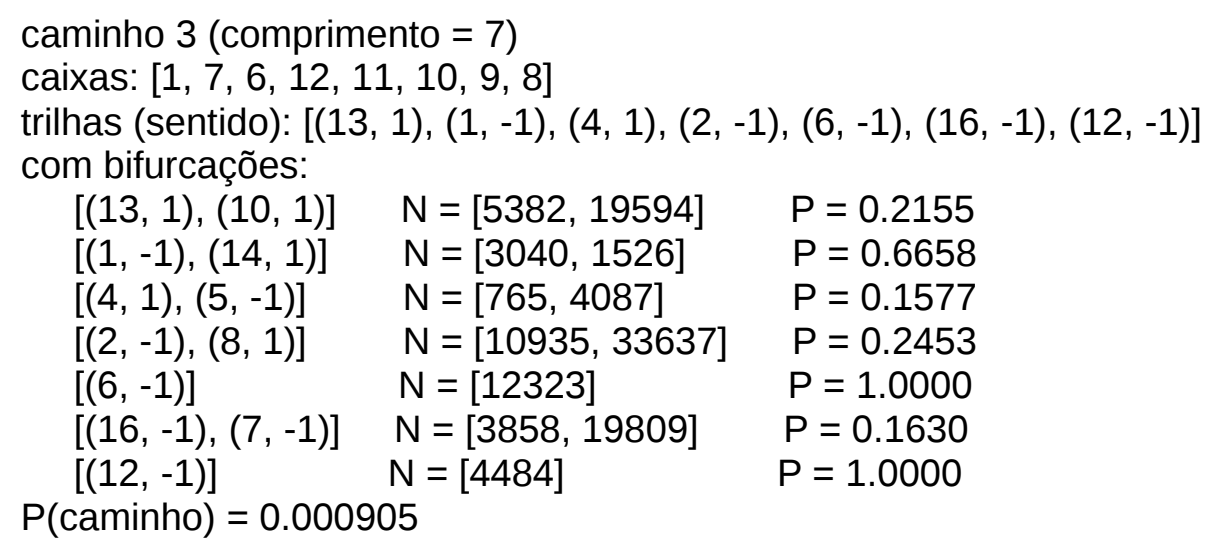

Agrupando os caminhos de acordo com os seus comprimentos (figura 6), antes de mais nada, observa-se que embora os caminhos mais curtos apresentem individualmente maior probabilidade, os caminhos de comprimento sete, por serem mais numerosos, possuem conjuntamente uma probabilidade maior. Dessa forma, embora os caminhos menores sejam mais prováveis, a estrutura do labirinto favorece a formação de caminhos de comprimento sete, constituindo um desafio ao estabelecimento de uma trilha de forrageamento por um dos caminhos mínimos. 
Figura 6.Distribuição de probabilidades dos caminhos segundo o comprimento.
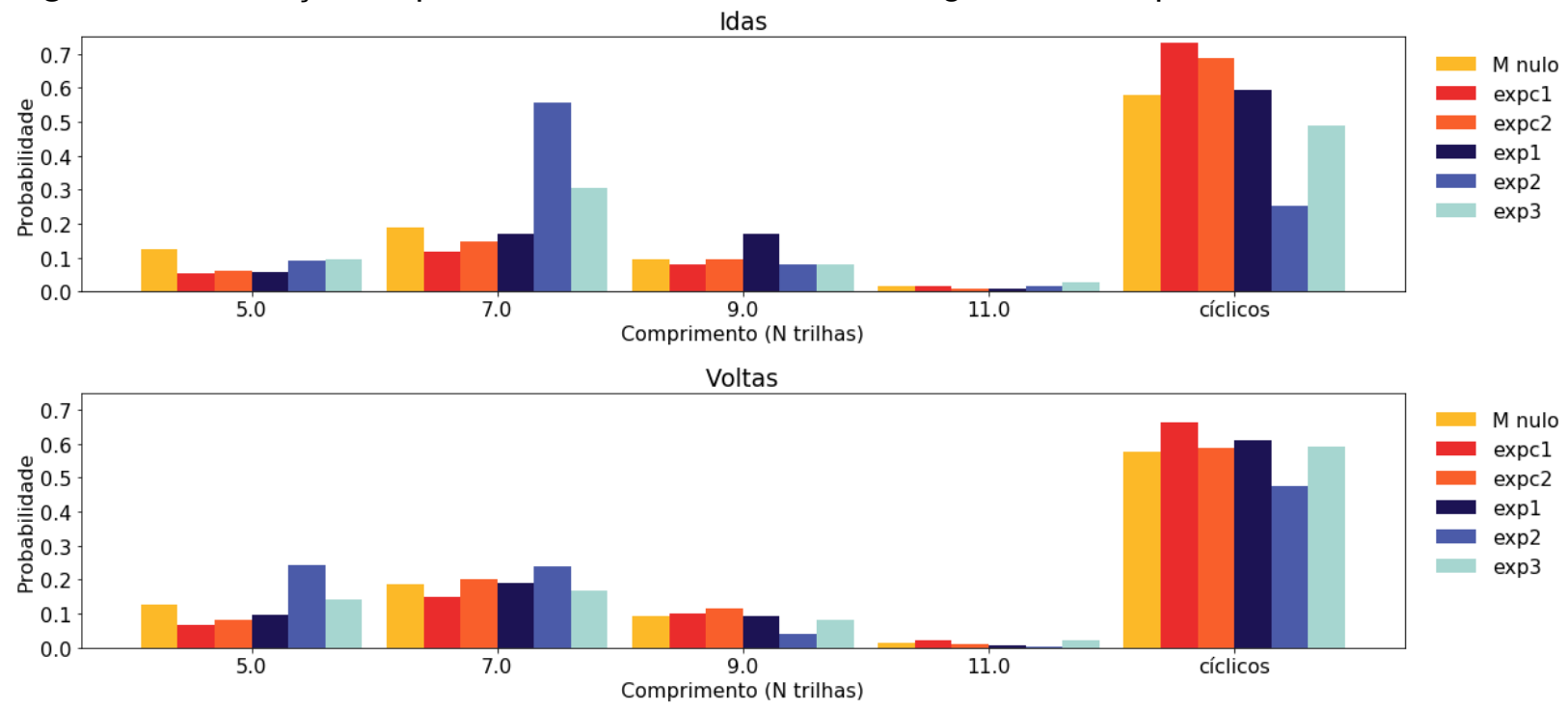

Comparação das probabilidades entre o modelo nulo e os diferentes experimentos.

Observando as distribuições de probabilidades de caminhos segundo os seus comprimentos (figura 6), de forma geral, os controles apresentam probabilidades reduzidas de caminhos mínimos, e mesmo de caminhos de comprimento sete, em relação ao modelo nulo. Entretanto, apresentam maiores probabilidades de caminhos cíclicos do que o modelo nulo. Contrariamente, nos experimentos com folhas, há uma otimização para o caminho mínimo no exp2 (volta), um aumento bastante expressivo na probabilidades dos caminhos de comprimento sete (exp2 e 3 ida) e nove (exp1 ida) se comparados ao modelo nulo. Além disso, os experimentos com folhas apresentam redução das probabilidades dos caminhos cíclicos. Essas diferenças dos experimentos com folhas são ainda mais notáveis se comparados aos controles do que ao modelo nulo. Pode-se concluir que em se tratando das probabilidades dos caminhos em função dos seus comprimentos, o modelo nulo é intermediário em relação aos controles e experimentos com folhas. Isso se deve, em síntese, à dois aspectos. Primeiro, o de que nos controles há um favorecimento dos caminhos cíclicos, e segundo o de que nos experimentos com folhas há um favorecimento dos caminhos de comprimento cinco, sete, ou nove, à depender do caso.

Ainda considerando as probabilidades dos caminhos, é possível comparar os grupos segundo algumas medidas (tabela 1). A divergência de Kullback-Leibler entre as 
distribuições de todos os caminhos, sem agrupá-los segundo os comprimentos (KL P(c)), e o modelo nulo é sempre maior nos experimentos com folhas do que nos controles, com exceção da volta no exp1. Sendo assim, a dispersão dos controles parece ser mais próxima ao modelo nulo. A razão entre os valores de probabilidade do caminho mais provável de um experimento e sua probabilidade no modelo nulo (razão(uni)) reflete a grandeza do favorecimento daquele caminho na dispersão observada experimentalmente. Nos experimentos com folhas, essa razão foi sempre maior do que nos controles, com exceção da volta do exp1. Se esta razão já é bastante diagnóstica entre controles e experimentais, a lateralidade, dada pela razão entre a trilha mais provável e sua simétrica, apresenta o mesmo padrão, com valores ordens de grandeza maiores. Isso ocorre pois na medida em que uma trilha é preferida sua simétrica é preterida, de forma que a razão seja ainda mais expressiva. Isso pode ser observado nos valores da razão(sim). Conforme esperado, as convergências dos experimentos com folhas são todas maiores do que dos experimentos controle. Vale notar também que, especialmente nos experimentos com folhas exp2 e exp3, as convergências na ida são maiores do que as correspondentes na volta. Quanto à comparação com o modelo nulo, com exceção das medidas de convergência e a razão(uni.) no experimento controle expc1, todas as medidas observadas foram significativamente diferentes da hipótese nula (alpha 0.05). 


\begin{tabular}{|c|c|c|c|c|}
\hline & \multicolumn{2}{|c|}{ expc1 } & \multicolumn{2}{|c|}{ expc2 } \\
\hline & Idas & Voltas & Idas & Voltas \\
\hline KL comp. & 0.0615 & 0.0267 & 0.0359 & 0.0116 \\
\hline $\mathrm{KL} P(\mathrm{c})^{\star \star}$ & *0.1420 & *0.1557 & ${ }^{\star} 0.4483$ & ${ }^{\star} 0.3306$ \\
\hline $\max$ & $13,1,5,3,7,16,12$ & $12,16,7,11,10$ & $13,1,5,3,7,16,12$ & $12,16,7,3,5,1,13$ \\
\hline Pmax & 0.0361 & 0.0449 & 0.0705 & 0.0907 \\
\hline razão(uni)** & *1.1558 & 0.7178 & $\star 2.2576$ & $\star 2.9011$ \\
\hline $\operatorname{sim}(\max )$ & $10,11,3,5,4,8,9$ & $9,8,4,1,13$ & $10,11,3,5,4,8,9$ & $9,8,4,5,3,11,10$ \\
\hline $\operatorname{sim}(P \max )$ & 0.0222 & 0.0234 & 0.0150 & 0.0243 \\
\hline razão(sim) & 0.7113 & 0.3751 & 0.4814 & 0.7784 \\
\hline Lateralidade & 1.6250 & 1.9136 & 4.6893 & 3.7272 \\
\hline Conv. ${ }^{* *}$ & 0.1471 & 0.1429 & *0.2362 & ${ }^{*} 0.2343$ \\
\hline
\end{tabular}

\begin{tabular}{|c|c|c|c|c|c|c|}
\hline \multirow{3}{*}{ KL comp. } & \multicolumn{2}{|c|}{ exp1 } & \multicolumn{2}{|c|}{$\exp 2$} & \multicolumn{2}{|c|}{ exp3 } \\
\hline & Idas & Voltas & Idas & Voltas & Idas & Voltas \\
\hline & 0.0409 & 0.0044 & 0.3591 & 0.0847 & 0.0471 & 0.0040 \\
\hline $\mathrm{KL} P(\mathrm{c})^{\star \star}$ & *0.7042 & *0.4076 & *1.4233 & *0.9191 & *0.5999 & *0.4960 \\
\hline $\max$ & $10,11,7,6,2,8,9$ & $12,16,7,11,10$ & $10,11,7,6,2,8,9$ & $12,16,7,11,10$ & $10,11,7,6,2,8,9$ & $12,16,7,11,10$ \\
\hline Pmax & 0.1097 & 0.0901 & 0.5224 & 0.2356 & 0.1894 & 0.1329 \\
\hline razão(uni)** & $\star 3.5100$ & *1.4420 & *16.7181 & $\star 3.7696$ & *6.0621 & *2.1271 \\
\hline $\operatorname{sim}(\max )$ & $13,1,4,2,6,16,12$ & $9,8,4,1,13$ & $13,1,4,2,6,16,12$ & $9,8,4,1,13$ & $13,1,4,2,6,16,12$ & $9,8,4,1,13$ \\
\hline $\operatorname{sim}(P \max )$ & 0.0036 & 0.0225 & 0.0011 & 0.0062 & 0.0036 & 0.0072 \\
\hline razão(sim) & 0.1149 & 0.3603 & 0.0341 & 0.0998 & 0.1146 & 0.1152 \\
\hline Lateralidade & 30.5382 & 4.0020 & 490.2673 & 37.7699 & 52.8909 & 18.4599 \\
\hline Conv. ${ }^{* *}$ & $\star 0.2581$ & ${ }^{*} 0.2432$ & ${ }^{\star} 0.6990$ & $* 0.4557$ & ${ }^{\star} 0.3741$ & $* 0.3309$ \\
\hline
\end{tabular}

Tabela 1: 'KL comp' : divergência de Kullback-Leibler entre a distribuição de probabilidades de comprimentos entre 0 experimento e o modelo nulo; 'KL P(c): divergência de Kullback-Leibler entre a distribuição de probabilidades de todos os caminhos acíclicos do experimento e do modelo nulo; 'max': caminho acíclico de maior probabilidade observado no experimento; Pmax: probabilidade estimada do caminho max; 'razão (uni)': razão entre a probabilidade estimada e a do modelo nulo para o caminho max; 'sim(Pmax)': caminho simétrico ao max; 'razão(sim)': razão entre a probabilidade estimada e a do modelo nulo para o caminho simétrico ao max; 'Lateralidade': razão entre a probabilidade estimada do caminho max e do caminho simétrico a ele; 'Conv.': convergência, razão entre a probabilidade estimada do caminho max e a soma das probabilidades estimadas dos outros caminhos acíclicos. Os asteriscos duplos indicam as métricas para as quais se obteve p-valores, que quando significativos são indicados com asteriscos únicos. A interpretação dos resultados de caso é apresentada adiante. 
Embora os padrões gerais sejam identificáveis, uma interpretação conjunta do gráfico e da tabela para cada experimento é necessária para que se possa avaliar como se deu a dispersão em cada experimento pelos caminhos possíveis de forrageamento.

expc1: gráfico: apresenta um aumento da probabilidade dos caminhos cíclicos, especialmente na ida, em relação ao nulo uniforme, o que faz com que as outras probabilidades fiquem mais baixas. Além disso, há uma redução visível nos caminhos de comprimento cinco e sete, tanto na ida quanto na volta. Tabela: a trilha de probabilidade máxima não é nem duas vezes mais provável do que ela mesma no modelo nulo (razão(uni)), sendo o único caso em que não se rejeita a hipótese nula (Monte Carlo, idas expc1: 0.71, m.nulo: 0.1755, $p>0.99)$. Embora tenha uma preferência de quase três vezes em relação à simétrica (razão(sim)) apresenta uma convergência muito baixa, sendo também o único dos experimentos para os quais não se rejeita que as convergências sejam diferentes das obtidas no modelo nulo (Monte Carlo, idas: $=0.1471$, voltas: 0.1428 , mulo $=1.00$ ida e volta, $p>0.99$ ). A divergência de Kullback-Leibler entre a distribuição de probabilidades de todos os caminhos e o modelo nulo é bastante baixa (KL $P(c)$ ) embora rejeite-se a hipótese nula, o cenário do modelo nulo é bastante próximo.

expc2: gráfico: em comparação com o modelo nulo apresenta uma probabilidade bastante reduzida dos caminhos de comprimento cinco (ida e volta) e na de sete (ida). Além disso, apresenta uma maior probabilidade de caminhos cíclicos na ida. Tabela: As divergências de Kullback Leibler são baixas entre as distribuições de probabilidade de todos os caminhos $(\mathrm{KL} P(\mathrm{c})$ ) indicando ainda uma similaridade relativamente alta com o modelo nulo. $\mathrm{O}$ caminho de probabilidade máxima foi duas vezes mais provável do que no modelo nulo (razão(uni)). Comparativamente menor do que o observado nos experimentos com folha. $O$ mesmo ocorre com a lateralidade.

exp1: gráfico: o que chama mais a atenção é a redução das probabilidades das trilhas de comprimento cinco especialmente na ida - indicando uma baixa otimização - e a preferência pelas trilhas longas, tanto de sete quanto de nove trechos. Ambas apresentaram a mesma probabilidade, mas a da trilha de nove trechos é superior ao esperado no modelo nulo, enquanto a de sete não. Provavelmente não há uma preferência muito definida no primeiro anel, gerando uma divisão do fluxo entre dois caminhos possíveis. Entretanto, a 
probabilidade dos caminhos de comprimento nove é reduzida na volta. Tabela: O aumento da probabilidade da trilha máxima em relação ao modelo nulo (razão(uni)) é bastante expressiva na ida, acompanhada pela redução da probabilidade da trilha simétrica (razão(sim)). Entretanto, a convergência para a trilha de maior probabilidade, apesar de maior do que dos experimentos controles, ainda é muito baixa. Portanto, apesar de haver aparentemente a formação de uma trilha preferencial, não há uma concentração do fluxo nela. De forma geral, esse experimento ainda ficou muito próximo do modelo nulo apesar de haver diferenças expressivas.

exp2: gráfico: é bastante notável o aumento da probabilidade dos caminhos de comprimento sete. $\mathrm{O}$ aumento reflete, provavelmente, o aumento do forrageamento uma vez que a probabilidade dos caminhos cíclicos também diminuem. Outro aspecto bastante relevante é a diferença no favorecimento das trilhas de comprimento cinco na volta em relação à ida. Portanto, houve uma otimização para o caminho mínimo na volta. Tabela: Fica visível a formação de uma trilha preferencial, tanto na ida quanto na volta. $\mathrm{Na}$ ida, a trilha de maior probabilidade é mais do que dez vezes mais provável do que o esperado segundo o modelo nulo (razão (uni)). Curiosamente, o aumento da probabilidade das trilhas de comprimento cinco na volta é acompanhado pelo decréscimo da convergência, o que pode indicar um retorno por trilhas alternativas. Isso é evidenciado pela lateralidade reduzida no retorno ao ninho.

exp3: gráfico: apesar da ida mostrar um aumento das probabilidades das trilhas de comprimento sete, a volta é muito próxima ao modelo nulo. Tabela: na volta, tem uma dispersão próxima a do modelo nulo dada a menor divergência de Kullback-Leibler na distribuição de probabilidades dos caminhos em geral (KL $P(c)$ ) se comparado à ida. $O$ mesmo ocorre com a razão (uni) e a lateralidade. Em conjunto, o retorno aparentemente tem uma dispersão mais próxima ao modelo nulo, o que poderia ser o caso de fluxo de forrageamento com poucos indivíduos transportadores no retorno.

\subsection{Conclusões}

Como se pode observar, nenhum experimento apresentou formação de trilha de forrageamento em um dos caminhos mínimos na ida, somente na volta. Os caminhos de 
comprimento cinco só foram mais prováveis do que o esperado segundo o modelo nulo no sentido de volta do experimento 2. É, portanto, bastante nítido que não houve otimização das trilhas de forrageamento por convergência para o caminho mínimo como seria esperado no caso dos experimentos com folhas.

Aliás, no que diz respeito ao comprimento dos caminhos, a grandeza das diferenças observadas entre os controles e os experimento, salvo o experimento exp2, são reduzidas. Ainda assim, são maiores do que as observadas entre qualquer um dos grupos (controle e com folhas) e o modelo nulo, uma vez que este apresentou uma distribuição intermediária. Dado que o modelo nulo assume probabilidade de exploração com distribuição uniforme nas bifurcações (probabilidade de 0.5 para cada lado) representa um cenário em que a dispersão corresponde à máxima exploração, a expectativa seria de que ele fosse um limite mínimo das probabilidades dos caminhos acíclicos, e máximo dos cíclicos. Entretanto, se por um lado as probabilidades dos caminhos de forrageamento são menores nos experimentos controle do que no modelo nulo, por outro, as probabilidades dos caminhos cíclicos são maiores. Este outro lado revela que a dispersão observada nos experimentos controle não são máximas por conta de haver uma concentração em caminhos cíclicos, possivelmente por conta das formigas favorecerem o movimento circular no primeiro anel, priorizando a proximidade à colônia.

Apesar das diferenças entre controles e experimentos com folhas serem pequenas, são consistentes uma vez que todos os experimentos apresentam maiores probabilidades nos caminhos de comprimento cinco, sete e, em alguns casos, nove, além de menores probabilidades nos caminhos cíclicos. Entretanto, embora esse padrão seja válido na ida, na volta ele é menos visível. Essas diferenças entre controles e experimentais refletem a formação de trilhas de forrageamento nos experimento com folhas em caminhos de comprimento cinco (exp2 volta), sete (exp2 ida e exp3 ida) e nove (exp1 ida). A grande diferença observada no exp2 reflete a maior intensidade de forrageamento nesse experimento, conforme aponta também a alta convergência para a trilha preferencial.

Da mesma forma, nos experimentos, a razão entre a probabilidade da trilha mais provável no experimento e no modelo nulo (razão (uni)) foi sempre maior do que nos controles, o que reforça o quadro de formação de trilha preferenciais de forrageamento. Há também nos controles a possibilidade de formação de trilhas preferenciais espontâneas. Em 
algum grau elas ocorrem, como se pode perceber nas medidas de lateralidade, em detrimento das suas simétricas. Entretanto apresentam sempre baixa convergência e portanto são menos intensas.

Vale notar também que as convergências na ida são sempre maiores do que as correspondentes na volta. Mesmo nos experimentos com alimento. Nestes, além da redução da convergência, em geral, diminuem as probabilidades dos caminhos acíclicos e aumentam a dos cíclicos. Parece razoável que esses efeitos estejam relacionados uma vez que a redução da convergência implica uma menor concentração do fluxo na trilha preferencial o que reduz sua probabilidade. 
7. Análise das dispersões 


\subsection{Objetivos específicos}

Primeiramente, a análise dos fluxos busca obter uma caracterização geral das dispersões observadas, não só dos caminhos de forrageamento, mas do fluxos totais e específicos em cada trilha e sentido. O objetivo é buscar se há algum padrão que seja diagnóstico dos grupos controle ou dos experimento com folhas.

Uma vez observadas e caracterizadas as dispersões de cada experimento, através da comparação entre elas busca-se, fundamentalmente, responder duas perguntas. As dispersões são espaço-temporalmente distintas? As dispersões refletem o grau de empenho nas atividades de exploração e forrageamento?

Quanto à primeira, buscou-se avaliar quais são os elementos determinantes das diferenças entre a dispersão de um experimento e outro. Além disso, verificar como os modelos se encaixam nessas diferenças. Quanto à segunda, procurou-se observar as diferenças de forma a relacioná-las aos comportamentos subjacentes de forma quantitativa através utilização de medidas de entropia informacional das dispersões. A relação entre a entropia e os comportamentos pode ser observada nos modelos, que são cenários exclusivos de um comportamento ou outro, e interpolada para os experimentos. Dessa forma, embora não se disponha de uma medida direta para avaliar o grau de empenho das colônias experimentais na exploração e forrageamento, os cenários obtidos pelas simulações fornecem as dispersões esperadas nos casos extremos do gradiente entre uma tarefa e outra no que diz respeito à dispersão espacial dos indivíduos pelo labirinto. Sendo assim, busca-se avaliar de que forma as medidas de entropia das dispersões podem ser representativas dos comportamentos subjacentes.

\subsection{Materiais e métodos}

Para a caracterização geral do fluxo foram comparados os fluxos totais dos experimentos ao longo do tempo. Posteriormente, para que se pudesse observar de forma mais específica as dispersões segundo a estrutura do labirinto, as contagens de cada trilha e sentido de cada experimento foram visualizadas segundo os escore-z correspondentes. Dessa forma, a identificação das diferenças entre quais trilhas foram mais ou menos utilizadas em cada experimento é mais fácil, pois o escore elimina as diferenças de 
magnitude dos fluxos. A comparação visual busca à identificação de padrões recorrentes entre os grupos, cuja interpretação seja diagnóstica.

Para que se pudesse comparar quantitativamente as dispersões dos experimentos ao longo do tempo, foram calculadas as diferenças nas contagens em uma mesma trilha, sentido e no mesmo intervalo. Preservando, dessa forma, a estrutura do labirinto no cálculo das diferenças. Mais precisamente, a diferença foi calculada como uma distância euclidiana entre os escores. Com os valores de distâncias euclidianas foi realizada uma clusterização hierárquica segundo o método de aglomeração de Ward, de minimização do aumento da variância interna. Esse método foi escolhido devido à fato de ser análogo à análise de variâncias (ANOVA). A cada momento é adicionado à um grupo já existente o ponto (ou experimento no caso) que menos adicionar à variância desse novo conjunto. Dessa forma, os grupos são formados de forma a maximizarem a diferenças entre os grupos que seriam observados num teste ANOVA (segundo o valor da distribuição $F$ ). $O$ método de clusterização hierárquica produz, por fim, um dendrograma com os grupos hierarquicamente compostos de agrupamentos dos experimentos e modelos.

As análises de entropia buscam fazer as comparações das estratégias de cada caso usando uma caracterização mais própria do processo e menos específica, especialmente no que diz respeito às particularidades geométricas e idiossincráticas dos experimentos. As medidas de entropia são mais sintéticas, refletindo características importantes quanto a uniformidade ou especificidade das dispersões sem a complexidade das comparações trilha a trilha. Nesse sentido ela busca atingir de forma mais direta as estratégias ou o comportamento subjacente através das propriedades das dispersões. Para isso, é essencial posicionar os resultados dos modelos como referência para interpretação dos resultados experimentais.

$$
H=-\sum_{i=1}^{n} P\left(x_{i}\right) \ln P\left(x_{i}\right)
$$

Para cada réplica experimental foi calculada a entropia informacional de Shannon, segundo a fórmula acima. Em cada réplica, a probabilidade de utilização de uma dada trilha, num sentido e num dado momento $\left(P\left(x_{i}\right)\right)$ é obtida através do cálculo da frequência relativa daquela trilha em relação à contagem total (somatória de todas as trilhas) dentro do 
intervalo de tempo de meia hora. Sendo assim, para cada réplica experimental e para os modelos simulados foi obtida uma série temporal da entropia informacional da dispersão à cada meia hora Para os modelos foram construídos intervalos de confiança de 99\% com base na distribuição t, utilizando os resultados obtidos nas simulações.

Além disso, foram obtidas as entropias cruzadas entre cada experimento e o modelo nulo e as entropias cruzadas entre cada experimento e o modelo de forrageamento de menor distância. A entropia cruzada é uma medida frequentemente usada na seleção de modelos, que calcula quantos bits uma dada distribuição necessita para representar outra, uma vez que representar uma distribuição a partir de outra não idêntica é sempre ineficiente, sempre requer mais bits. Nesse sentido, é uma medida interessante do ponto de vista do problema em questão, pois indica o quanto uma dispersão pode ser obtida a partir da outra, ou ainda, fornece uma medida quantitativa proporcional ao número de movimentações necessárias para se obter uma a partir da outra.

$$
\begin{gathered}
H(p, q)=H(p)+D_{K L}(p \| q) \\
D_{K L}(p \| q)=-\sum_{i=1}^{n} P\left(x_{i}\right) \ln \frac{P\left(x_{i}\right)}{Q\left(x_{i}\right)}
\end{gathered}
$$

Para o cálculo das entropias informacionais cruzadas procedeu-se de acordo com a primeira das fórmulas acima. A entropia cruzada entre uma dispersão de referência ( $p$, no caso um dos modelos) e a observada numa réplica experimental(q) é dada pela entropia da dispersão de referência acrescida da divergência de Kullback-Leibler entre as duas. $O$ cálculo da divergência de Kullback Leibler é bastante parecido com o da entropia informacional de Shannon, com a diferença que no último termo calcula-se o logaritmo da razão entre a probabilidade segundo a distribuição de referência e a outra. No caso, isso significa a razão entre o fluxo relativo numa dada trilha e sentido num modelo de referência e o fluxo relativo na mesma trilha e sentido num experimento.

\subsection{Resultados}

\subsubsection{Fluxos totais}

Em cada experimento, os eventos de contagem de formigas foram agrupados em intervalos de 30 minutos. Todas as análises foram realizadas com as contagens referentes à esse intervalo. Para a observação da atividade global da colônia, somou-se, em cada 
intervalo, as contagens de todas as trilhas e sentidos de um mesmo experimento (figura 7). Há uma diferença importante no nível de atividade entre os experimentos, sendo que nos experimentos com folhas exp1 e exp3 a atividade foi maior do que nos experimentos controle, com exceção do final dos experimentos, em que há uma queda acentuada da atividade. O experimento 3 destaca-se bastante dos demais pela intensidade da atividade. Já o experimento exp2 apresenta níveis iguais aos dos experimentos controle. Apesar das variações de fluxo ao longo do tempo, as diferenças entre experimentos se mantém mesmo quando o fluxo é baixo, indicando que possivelmente não é fruto exclusivamente do aumento de atividade.

Figura 7. Fluxo total de formigas no labirinto ao longo do tempo.

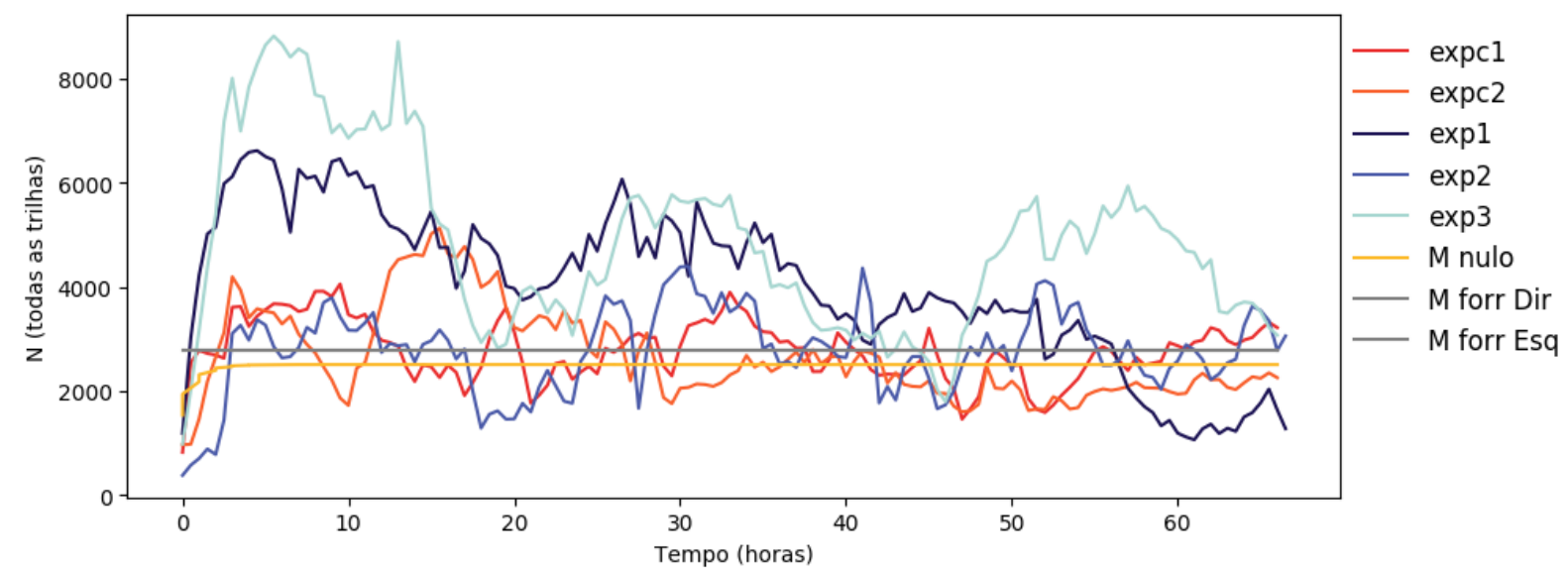

Há uma presença marcante de ciclos de atividade em todos os experimentos. Independente da intensidade do fluxo global, ele sempre cai e aumenta em momentos próximos entre os experimentos. Há, a grosso modo, 3 picos de atividade visíveis mais ou menos simultâneos entre os experimentos, um próximo das dez horas, um próximo das 30 e um próximo das 55 , sendo que este já não ocorre em todos. Além disso, a atividade segue um padrão que lembra um oscilador harmônico amortecido uma vez que, em cada experimento, os picos de atividade subsequentes são menores do que os anteriores. Exceto no experimento exp1. Esse aspecto parece ser decorrente do grande número de formigas que sai do ninho quando exploram um ambiente inteiramente novo, provocando um pico inicial de atividade muito grande. A quantidade de formigas nos modelos têm uma fase curta de aumento imediatamente após o início, mantendo-se estáveis até o fim. Isso mostra que os métodos de parametrização do modelo utilizando dados experimentais atingiram condições de equilíbrio entre a entrada e saída de formigas. 


\subsubsection{Diferenças entre as dispersões}

Para que se possa visualizar as trilhas mais utilizadas em cada experimento e a diferença entre eles, primeiro, observou-se a contagem ao longo de todo o experimento em cada trilha e sentido. Para eliminar as diferenças de intensidade de fluxo entre os experimentos foram utilizados os escores-z das contagens.

Figura 8. Mapas de calor da atividade (escore z) em cada trilha e sentido nos experimentos controle.
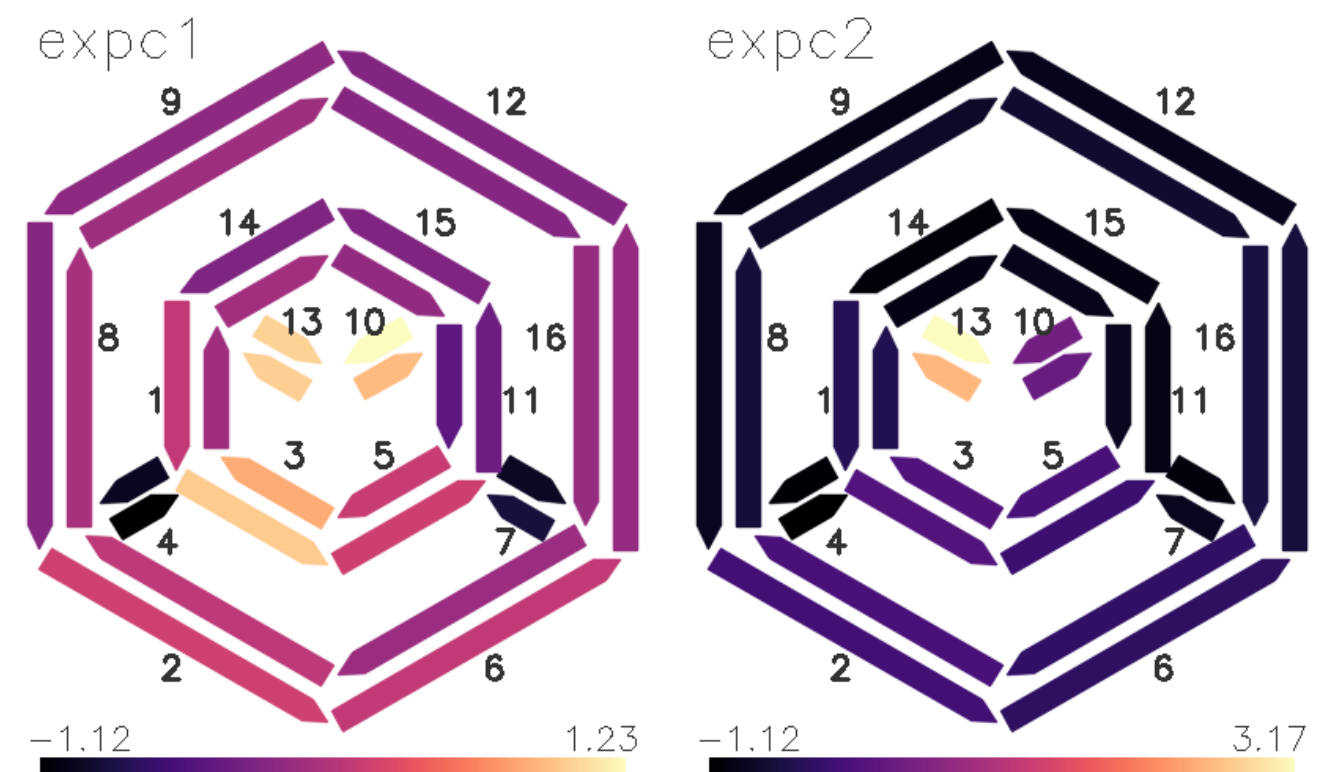

A escala de cor foi normalizada para cada experimento separadamente.

Figura 9. Histogramas com o escore $z$ em cada trilha e sentido nos experimentos controle.

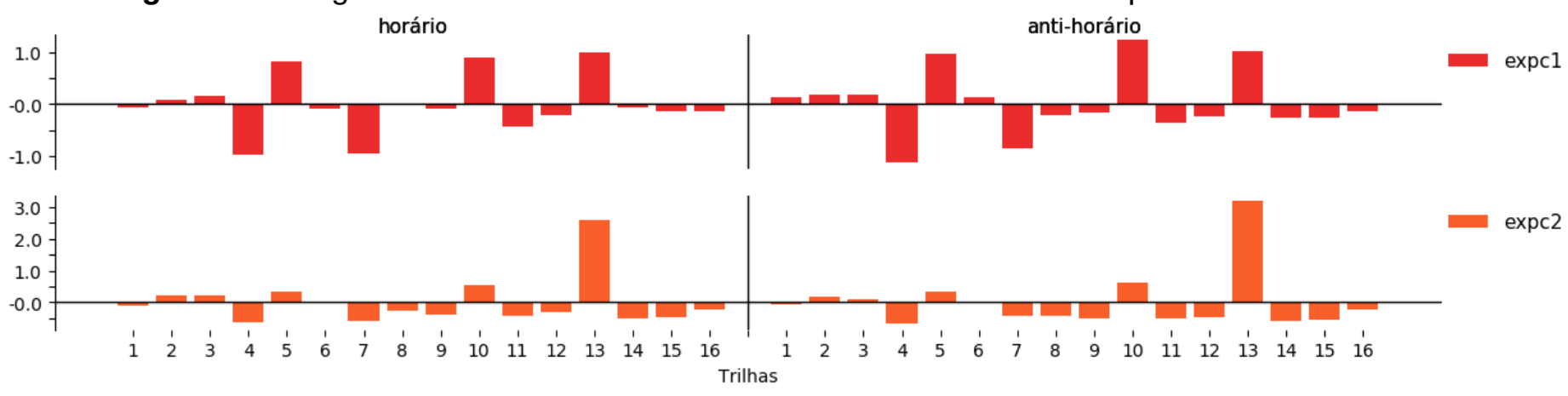

expc1: fluxos nas trilhas se desvia pouco da média, exceto pelas trilhas 10 e 13 (acessos à colônia), e 4 e 7 (passagens entre anéis interno e externo). Há um fluxo acima da média nos acessos à colônia, sem preferência clara entre trilhas 10 e 13 tanto na ida quanto na volta, embora a volta pela 10 tenha sido levemente maior. Já os fluxo nas trilhas 4 e 7 nos dois sentidos estão bastante abaixo da média, indicando a baixa transição entre anéis, 
reforçando a probabilidade de caminhos cíclicos conforme anteriormente observado. Esse padrão é ainda reforçado pelo fato de que os fluxos nas bifurcações, no sentido horário, 5h é maior que $7 \mathrm{~h}$, e $1 \mathrm{~h}$ maior do que $4 \mathrm{~h}$; no sentido anti-horário na trilha 3ah é muito maior do que na 4h, e na 11ah é maior do que na $7 \mathrm{~h}$, indicando que diante dessas bifurcações há uma preferência por manterem-se no mesmo anel. Todas as trilhas do anel exterior tiveram fluxo bem próximo da média.

expc2: o fluxo na trilha 13, tanto na saída quanto no retorno à colônia é muito maior do que em qualquer outra trilha. Isso se deveu ao fato de que as formigas depositaram lixo na caixa ao final da trilha 13. No anel interno pode-se observar fluxo nas trilhas 1 e 3 , e um pouco mais baixo na 5. Já no anel externo, a maioria teve fluxo abaixo da média, provavelmente porque a trilha 13, deve ter elevado a média de fluxo. Entretanto pode-se observar fluxo considerável nas trilhas 2 e 6.

Figura 10. Mapas de calor da atividade (escores z) em cada experimento com folhas.
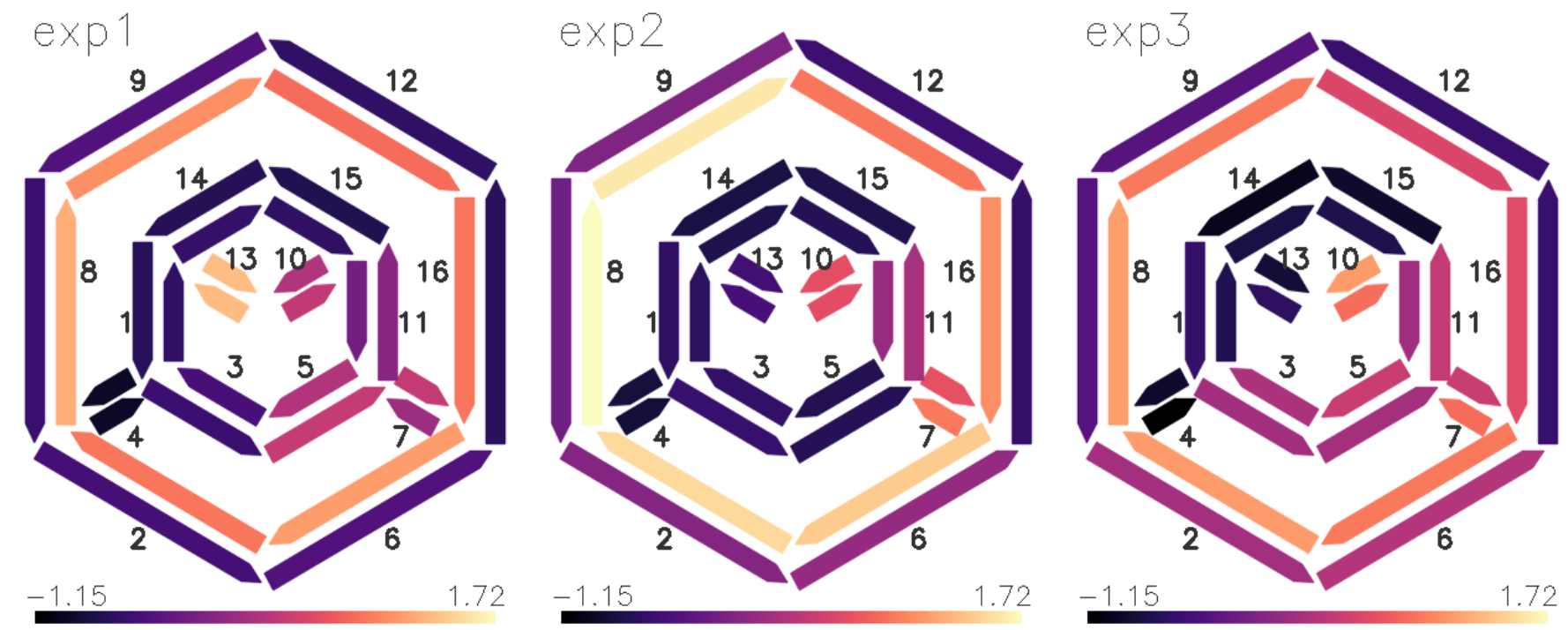

A escala de cor foi normalizada para todos os experimentos conjutamente.

Figura 11. Histogramas com o escore $z$ em cada trilha e sentido nos experimentos com folhas.

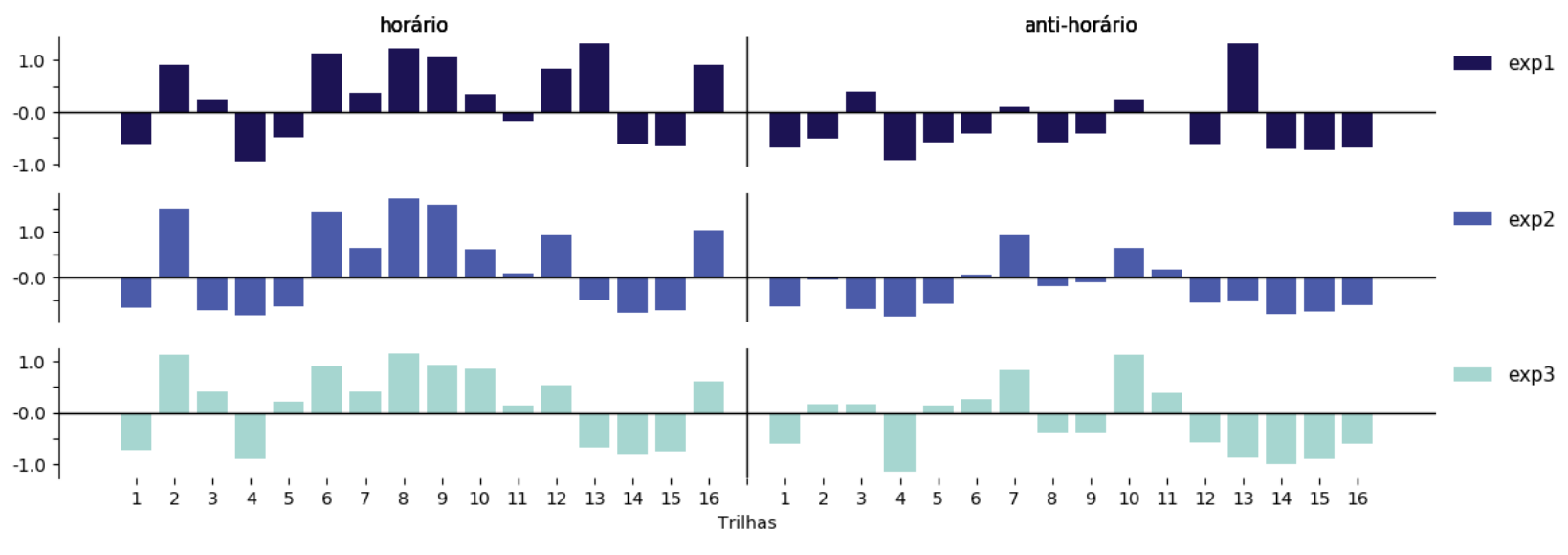


que apesar da preferência pela trilha 13 , o fluxo se divide entre os trechos $[13,1,3,5]$ e $[10$, 11]. Conforme observado na análise de probabilidades dos caminhos de forrageamento, há uma probabilidade alta e semelhante dos caminhos de comprimento nove e sete na ida, sendo que desses, somente o de nove é maior do que o esperado segundo o modelo nulo. Isso reforça ideia de que há uma divisão do fluxo no primeiro anel, de forma que não se possa distinguir se um somente um deles corresponderia à formação de trilhas de forrageamento. A passagem para o segundo anel é realizada preferencialmente pela trilha 7. A partir desta, observa-se um fluxo preferencial no sentido horário, produzindo uma ida até a caixa das folhas diferente da volta.

exp2: o caminho preferencial é de mais fácil visualização nesse experimento. Há uma preferência pela saída e retorno à colônia pela trilha 10 e pela transição entre anéis pela 7 , em ambos os sentidos. No caminho de ida, pode-se observar com bastante clareza a utilização do caminho [10h, 11h, 7h, 6h, 2h, 8h, 9h], bem como o retorno pelo caminho [12h, 16h, 7ah, 11ah, 10ah]. No entanto, ainda pode-se observar algum fluxo de retorno pelo caminho [9ah, 8ah, 2ah, 6ah].

exp3: há preferência pelos mesmos caminhos de ida e volta do experimento anterior. Entretanto o fluxo nas trilhas 5 e 3 em ambos sentidos, 2ah e 6ah, são maiores do que no exp2.

Figura 12. Mapas de calor da atividade (escores Z) nos modelos nulo e de forrageamento.
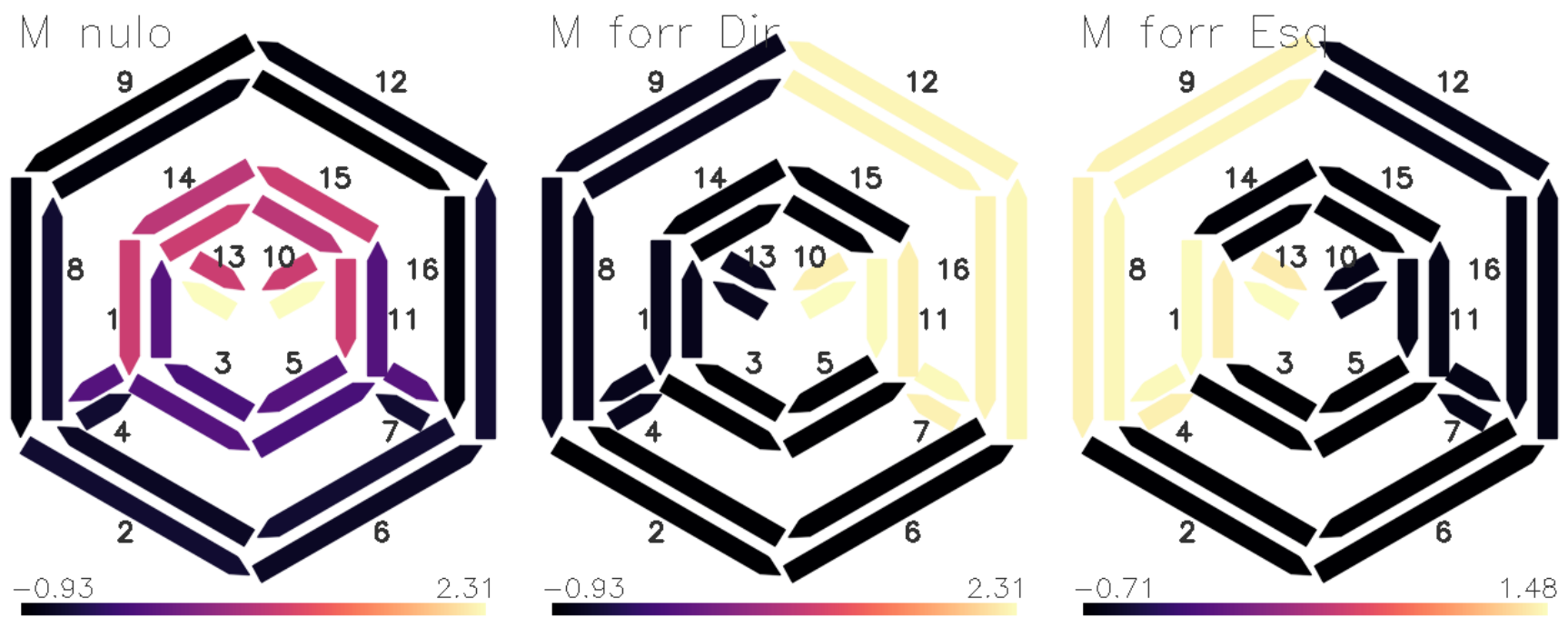

A escala de cor foi normalizada para cada experimento separadamente. 
Figura 13. Histogramas com o escore $z$ em cada trilha e sentido nos experimentos com folhas.

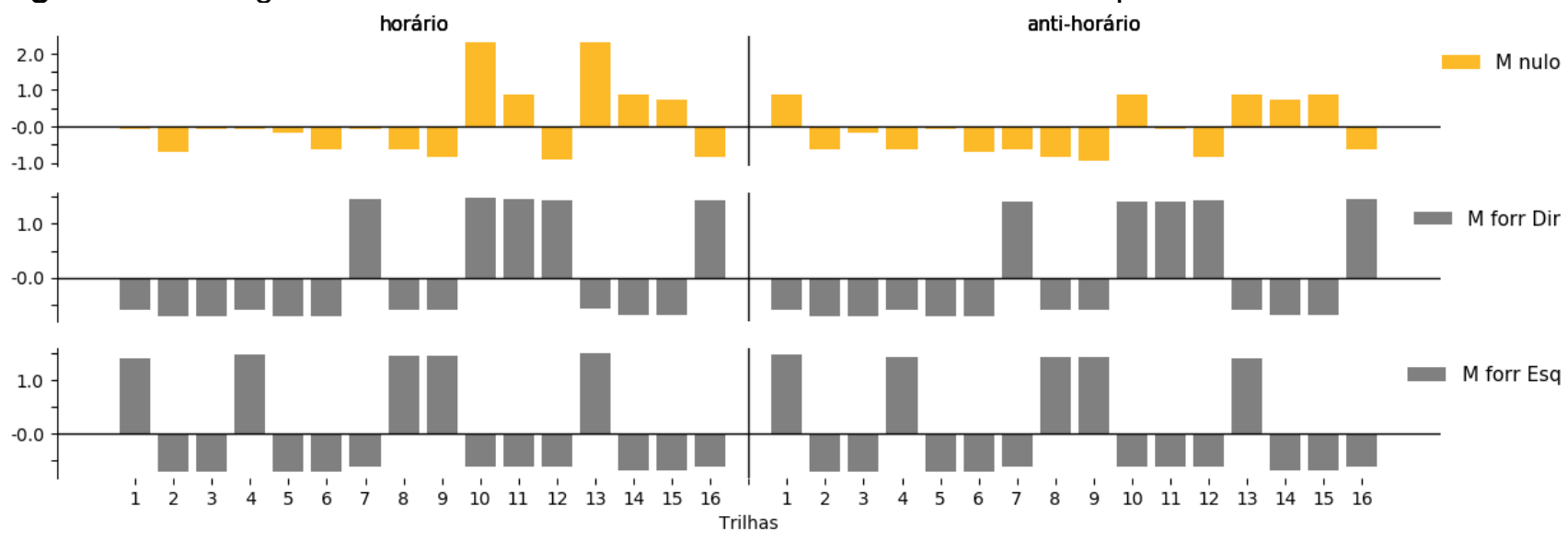

Modelo nulo: o fluxo é determinado pela proximidade da colônia. Não há preferências entre as trilhas 10 e 13, 1h e 14ah, 11h e 15ah, e consequentemente também não há entre 1 e 11. Tem um fluxo baixo na 3 e 5 se comparado aos experimentos, e maior nas trilhas 4 e 7 se comparado aos controles.

Modelo de forrageamento: Foi necessário dividir o modelo de forrageamento entre as réplicas que convergiram para caminhos à direita da colônia e à esquerda, para que a sobreposição dos dois casos não impossibilitasse a visualização do padrões de convergência para um lado ou outro. O fluxo converge totalmente para os caminhos mínimos de cada lado.

De forma geral, foi possível observar nos experimentos controle a ausência de trilhas preferenciais visíveis. O fluxo em todas as trilhas se diferencia muito pouco do fluxo médio. Entretanto, se compararmos ao modelo nulo é possível observar diferenças importantes. Uma delas é que nos controles o fluxo pelas trilhas 4 e 7 , em ambos os sentidos é menor do que no modelo nulo. Isso significa que há pouca transição entre os anéis, embora haja fluxo em cada um. Provavelmente os indivíduos que chegam ao anel externo tendem a movimentar-se mais pelo anel do que a voltarem para a colônia.

Outro aspecto interessante da comparação dos experimentos e do modelo nulo é que neste as trilhas 14 e 15 tiveram maior fluxo. Mesmo nos controles, em que a maioria das trilhas está próxima da média, o fluxo nas trilhas 14 e 15, em ambos os sentidos, foi sempre abaixo da média. Além disso, o fluxo nas trilhas 14 e 15 foi sempre inferior aos das 3 e 5 . Esse resultado, especialmente nos controles, indica que a presença das bifurcações 
90

das trilhas 4 e 7 provoca uma maior atração das formigas, mesmo na ausência de trilhas de forrageamento. O efeito de aumento de fluxo nas conexões para áreas mais distantes do ninho parece ser independente da marcação feromonal.

As trilhas preferenciais dos experimentos com folhas pelo caminho de ida foram pelas trilhas [10h, 11h, $7 \mathrm{~h}, 6 \mathrm{~h}, 2 \mathrm{~h}, 8 \mathrm{~h}, 9 \mathrm{~h}]$ e no retorno pelas trilhas [12h, 16h, 7ah, 11ah, 10ah]. No experimento exp1 e exp3 houve ainda algum fluxo considerável no anel interno nas trilhas 1 e 3 . Além dessas diferenças, no experimento exp1 também há bastante fluxo na trilha 13, e no exp3 há um fluxo nas trilhas 2ah e 6ah maiores do que nos outros. 0 experimento exp2 foi o que de fato apresentou uma maior concentração do fluxo nas trilhas preferenciais.

Os perfis de atividade em cada experimento, representados nos mapas e nos histogramas, foram comparados e agrupados de acordo com suas semelhanças através da clusterização hierárquica (figura 14). Os experimentos com folhas são mais próximos entre si, sendo que os experimentos exp2 e exp3 são mais próximos, e o exp1 é o mais próximo ao grupo formado pelos outros dois. Indicando que os fluxos nas trilhas não preferenciais no exp1 e exp3 são idiossincráticos, contribuindo para a diferença entre os dois. O dado mais próximo ao grupo formado pelos experimentos com folhas é o modelo de forrageamento de conversão para o lado direito. Nesse modelo há convergência para a mesma trilha mínima utilizada no retorno dos experimentos com folhas, diferindo dos experimentos somente na ida, no trecho do anel externo ([6h, 2h, 8h, 9h]).

Uma vez que o modelo de forrageamento para o lado esquerdo é o mais distante possível do modelo de forrageamento para o lado direito dado que não há uso de trilhas comuns nos dois, é natural que este tenda a ficar em outro grupo, separado do modelo de forrageamento à direita, em função da maximização das distâncias entre grupos. Ele é o dado mais diferente dentro do outro grande grupo de resultados, que compreende os experimentos controle e o modelo nulo. Neste, os dados experimentais também são mais próximos entre si do que se comparados ao modelo nulo. 
Figura 14. Clusterização hierárquica das dispersões no labirinto.

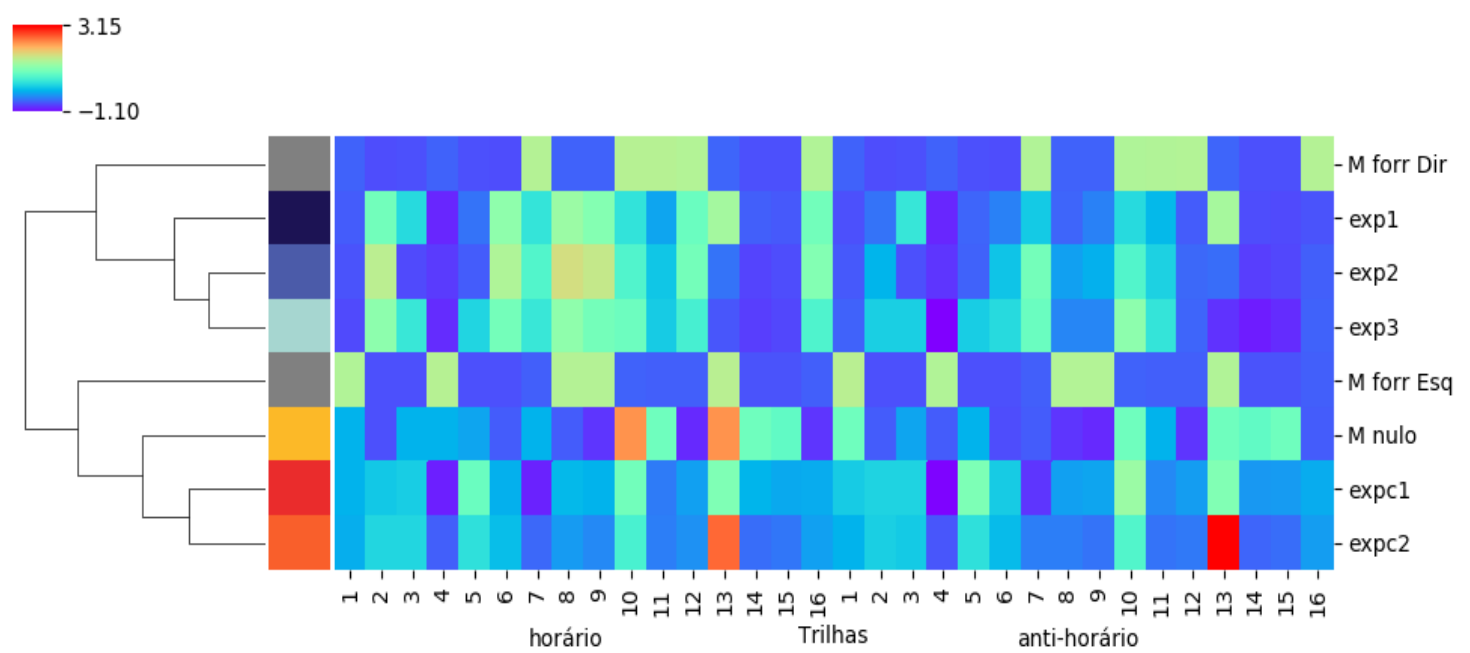

Os experimentos com folhas formam um grupo, junto ao modelo de forrageamento à direita. Já os controles e o modelo nulo formam outro grupo distinto.

Adicionalmente, as dispersões foram comparadas entre si, ao longo do tempo de experimento (figura 15). Utilizando as contagens em cada intervalo de 30 minutos, comparou-se as dispersões utilizando as contagens em cada trilha e sentido, entre os experimentos, agrupando-se hierarquicamente os mais próximos entre si também segundo o método de clusterização de Ward. 
Figura 15. Clusterização hierárquica da atividade no labirinto ao longo do tempo.
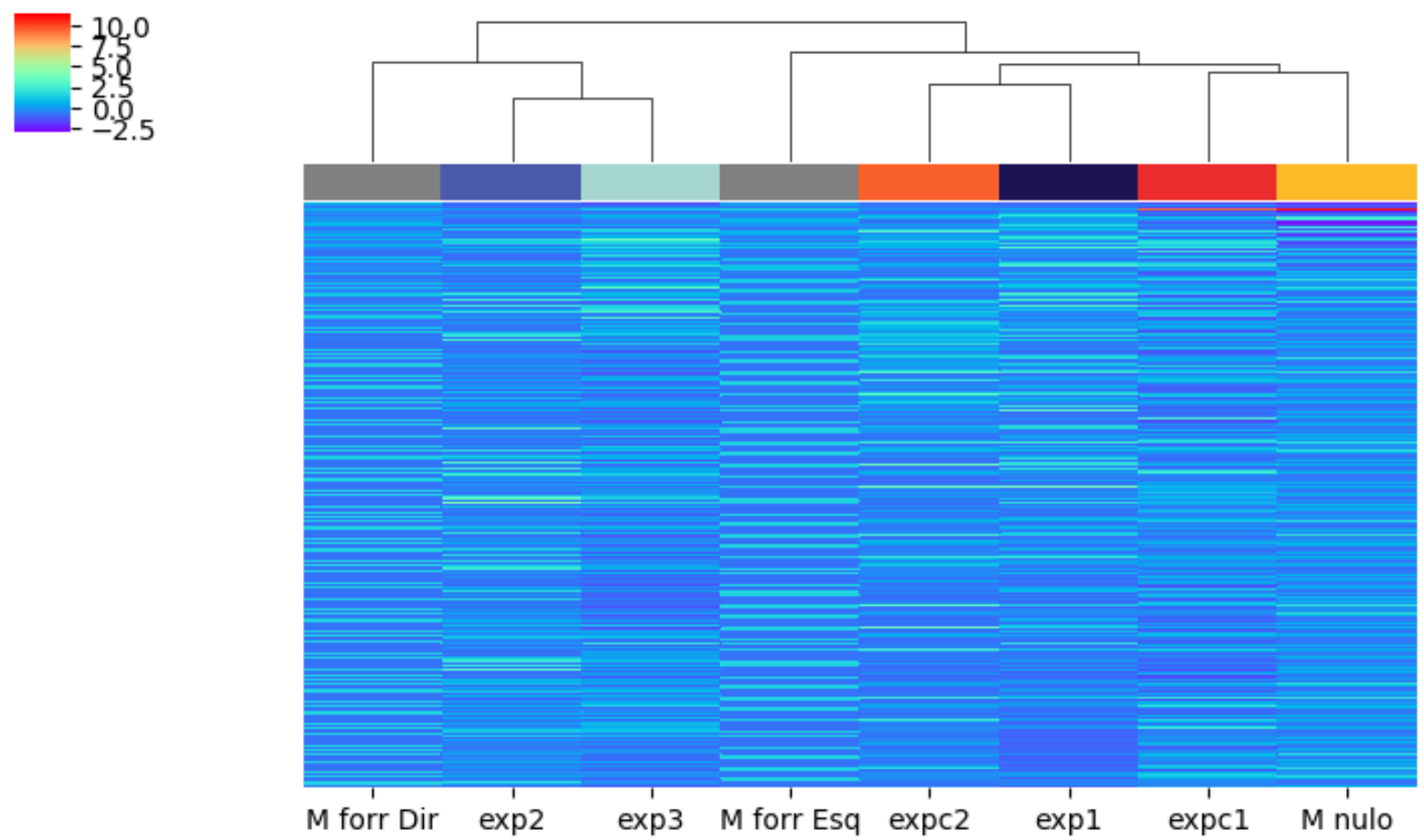

Ao longo do tempo as semelhanças entre o experimento exp1 e os outros com folhas sofrem variações, de forma que esse se agrupe aos experimentos controle.

Novamente, os grupos mais próximos obtidos foram os experimentos com folhas exp2 e exp3, em sequência o experimento exp1 e o controle expc2, o controle expc1 e o modelo nulo, respectivamente. Os experimentos exp2 e exp3 convergiram para o mesmo caminho mínimo à direita, sendo a convergências destes ambas maiores que o experimento exp1. Este, que na clusterização com os dados finais se assemelhou mais aos outros experimentos com folhas, apresentou provavelmente alguma alteração no padrão geral da sua dispersão ao longo do tempo de experimento. É possível que as trilhas de forrageamento tenham se formado mais tarde, ou ainda, que o forrageamento tenha cessado ao longo do experimento. Ainda outra possibilidade seria a de que a atividade neste experimento está fora de fase em relação aos outros. No entanto, a observação dos gráficos de fluxo total não parece indicar essa diferença. Possivelmente em função do fluxo na trilha 13 e 3 , esse experimento tenha se aproximado do experimento controle expc2 ao longo do tempo. Este, em função da atividade de depósito de lixo ao final da trilha 13, também apresentou alto fluxo nesta trilha. Já o experimento controle expc1, assim como o modelo nulo, não converge para lado nenhum, apesar de, como o expc2, apresentar uma maior probabilidade de caminhos à esquerda no primeiro anel, o que os aproximaria do modelo de forrageamento à esquerda. 
É interessante notar também que no primeiro grupo (exp2, exp3, modelo de forrageamento à direita) há um agrupamento por similaridade em dados de maior convergência, e de mesma trilha preferencial à direita no primeiro anel na ida, e sempre à direita na volta. No outro grupo, formado pelos grupos restantes houve baixa convergência, mesmo quando se observou a formação de trilha preferencial, no caso do exp1. Portanto, nesse segundo grupo está o modelo de forrageamento de convergência à esquerda separado dos demais, e depois os grupos de baixa convergência (expc2, exp1), e o grupo de sem trilhas preferenciais (expc1 e modelo nulo). Além disso, estes apresentaram probabilidades de caminhos à esquerda maiores do que o outro grupo. Dessa forma, ao se observar os grupos ao longo da dinâmica de utilização das trilhas, a convergência e a lateralidade têm um peso maior do que se analisados os grupos de acordo com o experimento todo.

\subsubsection{Entropia das dispersões}

Uma outra forma de comparar os diferentes experimentos e modelos é não considerar especificamente as trilhas e sentidos em si, mas caracterizar a dispersão por essas dimensões de acordo com a entropia informacional das distribuições de frequências observadas no labirinto. Dessa forma, é possível se obter uma caracterização mais geral das dispersões, independentemente das particularidades de lados preferenciais, enfatizando mais a convergência, ou, no sentido oposto, a uniformidade da dispersão. Quanto maior a incerteza em relação ao caminho, e por caminho entende-se a sequência de trilhas, maior a entropia da dispersão. Quanto maior a entropia, maior a exploração pelo labirinto. Por outro lado, a convergência reduz a incerteza em relação aos caminhos adotados na medida em que as probabilidades das trilhas nas bifurcações se distancia da distribuição uniforme, reduzindo a entropia da dispersão global.

Foram calculados intervalos de confiança usando a distribuição t para os modelos nulos e de forrageamento (figura 16). Por um lado, o modelo nulo tem um intervalo de confiança bastante estreito. Já o modelo de forrageamento apresenta uma faixa um pouco mais ampla de valores possíveis. Ou seja, aparentemente há um intervalo maior de entropias resultantes de dispersões produzidas pelo comportamento de forrageamento, embora esse tenda fortemente à convergência, do que pela exploração segundo o modelo de maior incerteza possível entre as decisões individuais das formigas. Se por um lado o 
comportamento individual é maximamente incerto, por outro, o resultado coletivo final é bastante estrito. Dessa forma, a convergência para a trilha mínima, por mais que quase certa, produz um espectro mais amplo de resultados possíveis.

Figura 16. Séries temporais da entropia informacional das dispersões.

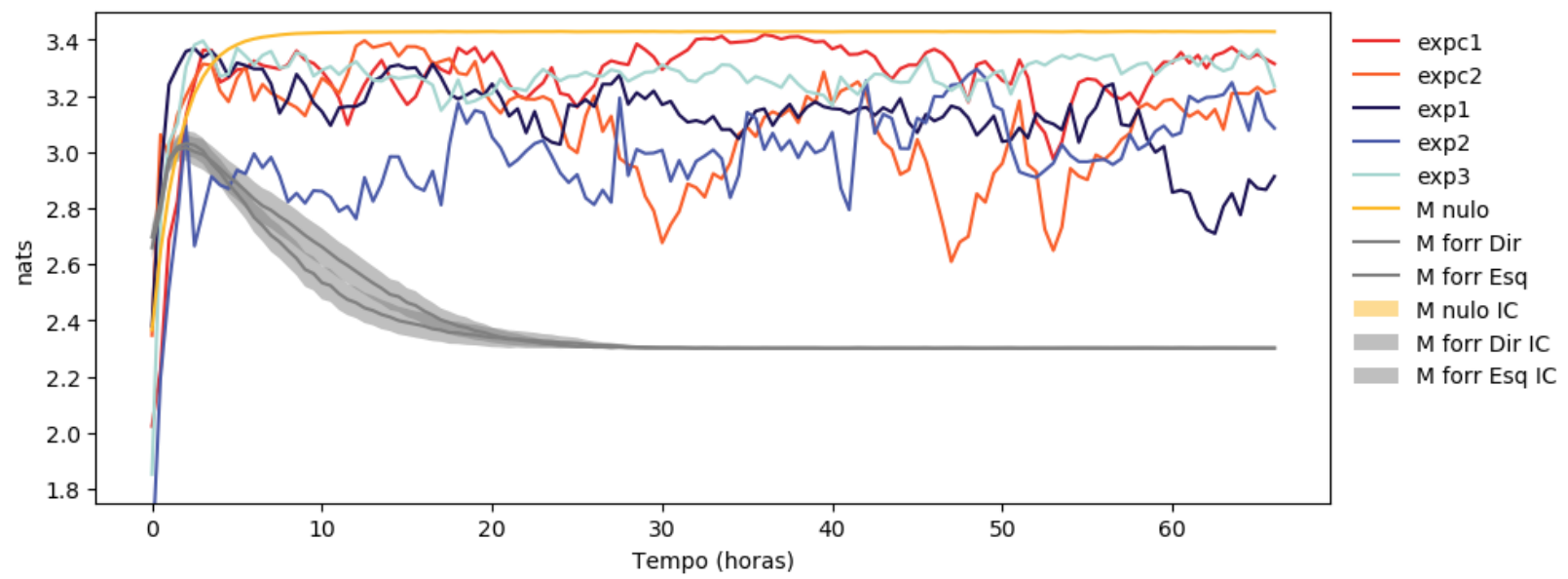

As séries dos modelos de forragemento e nulo têm intervalo de confiança de 99\%. Tanto os experimentos com folhas quanto controles apresentam comportamento semelhante, intermediário aos modelos, mais próximos ao modelo nulo.

Ao compararmos os resultado dos experimentos ao modelo nulo, diante da observação de que eles estão num patamar inferior aos limites do intervalo de confiança, é possível rejeitar a hipótese de que eles poderiam ser produzidos pelo mesmo comportamento definido pelo modelo nulo. É interessante notar que os experimentos também se encontram, na maior parte do tempo, fora do intervalo de confiança do modelo de forrageamento. Dessa forma, rejeita-se também a hipótese correspondente (exceto para parte do experimento com folhas exp2). Ou seja, os resultados experimentais estão num espaço intermediário entre os dois cenários. Isso é resultado também do fato dos dois modelos não produzirem conjuntamente duas hipóteses que delimitem o universo de possibilidades, aos moldes de um teste estatístico sensu Neyman Pearson. Entretanto, na medida em que eles delimitam tanto a margem superior quanto inferior, é possível concluir que o comportamento observado é intermediário entre os cenários dos modelos, de forma que o grau das diferenças é em si descritivo. Dessa forma, os comportamentos observados se aproximam muito mais da dispersão esperada para a exploração do que para o forrageamento. 
Comparando-se as curvas de entropia dos modelos e dos experimentos através da entropia cruzada (figura 17), é possível observar que os experimentos com folhas estão mais distantes do modelo nulo, ao passo que os experimentos controles estão mais distantes do modelo de forrageamento.

Não só o comportamento geral dos grupos confirma o padrão observado, mas também segundo uma avaliação quantitativa os efeitos particulares de cada experimento se mantêm coerentes. Por exemplo, o experimento exp2 é o mais distante do modelo nulo, e o mais próximo do modelo de forrageamento. No sentido oposto, os experimentos controle expc1 e expc2 se alternam no início, mas o experimento expc2 fica menos distante do nulo na segunda metade do tempo de experimento, predominando no mesmo intervalo como o mais distante do modelo de forrageamento.

Figura 17. Entropias cruzadas com o modelo nulo e com o de forrageamento.
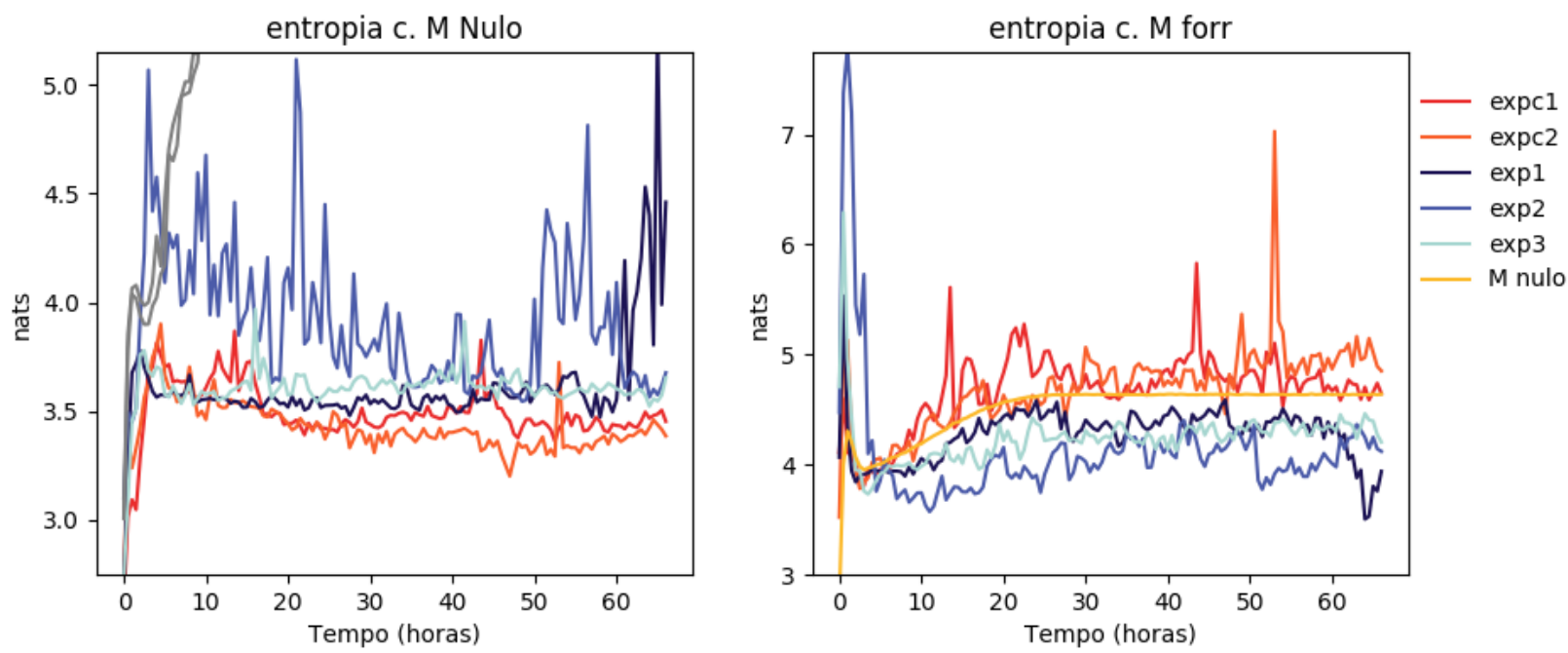

Enquanto os experimentos com folhas são mais distantes do modelo nulo e menos distantes do modelo de forrageamento, os controles apresentam o comportamento inverso.

Há um disparo súbito no início dado pelo maior crescimento da entropia nos experimentos do que no modelo. Entretanto, devido ao processo de convergência do modelo de forrageamento ser caracterizado por uma fase inicial de aumento da entropia, que corresponde à exploração do ambiente e a busca das alternativas de caminho entre a colônia e a fonte de alimento, as distâncias em relação à esse modelo também são 
predominantemente côncavas. Em contraste, uma vez que a entropia do modelo nulo cresce rapidamente e se estabiliza, as distâncias para os experimentos são mais estáveis.

\subsection{Conclusões}

Do ponto de vista das atividades, se o forrageamento leva ao aumento do nível de atividade por conta do recrutamento, faz sentido que os experimentos tenham uma atividade maior que os controles. Entretanto, o forrageamento é uma tarefa em que há horários preferenciais de execução e as diferenças entre o nível de atividade dos experimentos com folhas e controles persiste mesmo quando a atividade recua. Vale notar, uma vez que os picos também ocorrem nos experimentos controles, não é somente o forrageamento que apresenta algum periodismo. Tomando todos esses fatores em consideração, a ocorrência de forrageamento não parece ser o único determinante das diferenças dos níveis de atividade entre experimentos. Provavelmente o nível de atividade está relacionado à outros fatores momentâneos, como saúde do fungo, ou ainda como uma característica da colônia.

Uma das coisas que chama bastante a atenção é a presença marcante de ciclos de atividade em todos os experimentos. Independente da intensidade do fluxo global de cada experimento, ele sempre cai e aumenta em momentos próximos. Dessa forma, os dados observados refletem não um processo único, mas a repetição de ciclos. Esse é um aspecto interessante se observarmos posteriormente que as entropias não oscilam da mesma forma. Com exceção do experimento controle 2, que varia um pouco mais. Mas em geral, a entropia se estabiliza ao longo do tempo em valores mais altos. Aparentemente, apesar da diminuição do fluxo em períodos de baixa atividade a dispersão é mantida. Possivelmente com um número menor de formigas, ou mesmo com formigas transitando pouco entre as caixas, mas a dispersão não recua, mantendo a sua conformação espacial.

Ao se observar as distribuições de escores-z dos experimentos controles, o mais traço mais marcante é a pouca variação em relação à média. Salvos os altos fluxos nas trilhas 10 e 13 e baixos nas trilhas 4 e 7, em ambos os sentidos, as distribuições pouco fogem às médias. Aliás, é bastante curioso o fato de fugirem menos à média do que a distribuição do modelo nulo. Neste, trilhas próximas às 10 e 13, como a 1 e 11, tem um fluxo mais parecido. Nos experimentos controle, isso não ocorre. Além disso, eles destoam quanto os fluxos nas trilhas 4 e 7, 14 e 15, sendo que nos experimentos controle eles são 
sempre menores do que o esperado segundo o modelo nulo. O primeiro par, denota uma preferência por caminhos cíclicos num mesmo anel. O segundo, aponta um efeito de favorecimento do fluxo no sentido das bifurcações para o segundo anel. De alguma forma, o fato dessas bifurcações serem vias de passagem para outros caminhos mais longos, uma conexão para uma área maior, exerce algum efeito de atração do fluxo. Embora as formigas não sigam de fato para essas outras áreas além da bifurcação. Sendo assim, nos controles, a distância em relação ao ninho não parece ter a mesma relação com os fluxos como a que há no modelo nulo, sendo a presença das bifurcações um fator mais relevante. Outro aspecto que vale notar, é que possivelmente dado o fato de que eles apresentam alguma lateralidade para a esquerda no primeiro anel, eles se aproximam mais do modelo de forrageamento à esquerda do que os experimentos com folhas.

Quanto ao experimento com folhas exp1, vale notar que embora ele seja mais próximo dos controles segundo as diferenças espaciais ao longo do tempo e ser, dentre os experimentos com folha, o mais próximo do modelo nulo quanto à entropia, é possível observar que segundo o perfil geral dos escores finais das trilhas, ele se assemelha bastante aos outros experimento com folhas. Ou seja, embora a questão temporal, a lateralidade e convergência o aproximem dos controles, o padrão geral segundo as trilhas preferenciais é bastante próximo dos outros experimentos com folhas.

Os outros experimentos com folhas (exp2 e exp3) são os resultados mais próximos entre si. Entretanto, há uma diferença de fluxo total e de convergência relevante entre eles. O exp3 tem um fluxo muito mais alto e convergência relativamente mais baixa. Isso indica que o experimento exp3, apesar da convergência para o caminho preferencial de forrageamento, tem um fluxo exploratório maior, por exemplo nas trilhas 3 e 5 . Isso pode ser também confirmado pelas análises de entropia. Sendo assim, o exp3 aparenta um caso em que apesar da formação de trilha de forrageamento, o número de formigas transportadoras seguindo estritamente o caminho preferencial é menor, enquanto o fluxo exploratório é mais intenso. Já o exp2 apresenta um aspecto de forrageamento acentuado, com maior convergência à trilha preferencial, apesar da magnitude do fluxo ser mais reduzida.

À parte das questões de comparação entre os experimentos, os caminhos preferenciais são bastante curiosos. Nos experimentos com folhas, segundo o modelo 
canônico, não somente seria razoável que se esperasse a convergência do fluxo para uma das trilhas mínimas, mas também que ida e volta fossem as mesmas. Sendo esse fato ainda mais particular do que a não otimização do caminho. Dado que nem a marcação feromonal é polarizada, nem o mecanismo de amplificação da marcação prevê uma diferenciação entre ida e volta, a utilização de um caminho para ida e outro distinto para volta carece de algum mecanismo auxiliar, capaz de determinar qual caminho usado em cada sentido.

Comparando-se os intervalos de confiança dos modelos é possível concluir que há uma variedade maior de possibilidades correspondentes à cenários de forrageamento do que ao modelo nulo. Há muito poucas formas de ser uniforme. Essa condição restringe muito mais o espaço de resultados possíveis do que o forrageamento, muito embora ela corresponda exatamente à maior incerteza. O cenário de forrageamento também não é amplo o suficiente para abranger algum caso dos experimentos. O gradiente entre os dois ainda é bastante amplo.

Nas primeiras 20 horas não parece haver grande distinção entre os experimentos com folhas e os controles comparativamente ao restante do experimento. Exceto o exp2, que apresenta uma entropia bastante baixa neste intervalo. Ao longo do tempo restante, o exp2 aumenta a entropia, até que passadas 50h ele está num nível bem próximo aos outros. O expc2, por outro lado, reduz bastante a sua entropia após as primeiras $20 \mathrm{~h}$, mas de forma semelhante à ciclos. Outro aspecto curioso, é que a entropia dos experimentos cresce mais rapidamente que a do modelo nulo. Dessa forma, a dispersão inicial pelo labirinto parece ser uma atividade mais intensa, de forma que as distâncias em relação ao ninho não sejam determinantes da exploração. Imediatamente após a abertura do labirinto a exploração das formigas alcança o labirinto todo de forma mais rápida do que o esperado pelo modelo que corresponde à maior entropia, de forma que se possa concluir que a exploração de áreas ainda não visitadas seja fortemente prioritário no início.

As comparações entre os experimentos e os modelos são mais facilmente observadas nas comparações utilizando as entropias cruzadas. Em conjunto, as distâncias em relação ao modelo nulo e ao modelo de forrageamento compõe um cenário bastante razoável de que os controles são mais próximos do modelo nulo do que experimentos com folhas, em contrapartida estes são mais próximos do modelo de forrageamento do que aqueles. A medida de entropia cruzada representa, de forma indireta, a probabilidade de se 
obter as distribuições observadas à partir das distribuições dos modelos. Dessa forma ela é mais sensível às diferenças do que as comparações dos valores de entropia informacional simplesmente. Além disso, ela permite comparar para um dado experimento qual modelo melhor o representa.

As análises de entropia mostram em que porção do gradiente entre forrageamento e exploração os experimentos estão, entretanto não são suficientes para dar o diagnóstico uma vez que é necessário observar a formação de trilhas preferenciais de outras formas pois como as convergências são em geral baixas, a entropia não é sensível o suficiente. A mistura de efeitos de distância, favorecimento ou não de caminhos cíclicos, e principalmente a ida por um caminho e volta por outro fazem com que a entropia informacional seja menos sensível na representação da magnitude das diferenças do que a entropia cruzada. No entanto, as entropias cruzadas fornecem para cada experimento um par de distâncias, tornando a interpretação do cenário mais difícil. Ainda assim, a separação dos grupos é coerente entre as duas distâncias, de forma que os controles são mais distantes do modelo de forrageamento enquanto os experimentos com folhas são mais distantes do modelo nulo de exploração. 


\section{Discussão}




\subsection{Não convergência para o caminho mínimo}

O conjunto de dados coletados expressa de maneira detalhada os comportamentos apresentados pelas colônias. Foram avaliados no total mais de 2 milhões de eventos unitários da passagem de formigas pelo labirinto. Certamente, uma das observações que chama mais atenção, de início, é o fato de não se ter formado trilha de forrageamento num dos caminhos mínimos simétricos tanto na ida quanto na volta, em nenhum dos experimentos. Sem dúvida, a primeira expectativa é de que a trilha se forme no caminho mínimo. O mecanismo de reforço da marcação feromonal, com evaporação ao longo do tempo, tende a favorecer a convergência para a trilha mínima. O fato é bastante conhecido e existe ampla literatura à respeito, de forma que a não observação neste experimento não constitui evidência suficiente para a negação deste modelo. Entretanto, essa convergência é sempre uma probabilidade, de forma que a não ocorrência ou ainda a estabilização numa condição sub ótima são sempre possíveis.

Nesse sentido, as condições reais de experimentação podem eventualmente ter contribuído para que esse fato não tenha sido observado. Apesar do comportamento dos fluxos indicar aparentemente uma estabilização do fluxo na forma observada, ainda cabe a pergunta de se houvesse mais tempo a convergência para a trilha mínima na ida e na volta seria observada. Embora, não haja limites teóricos propostos para a formação da trilha mínima de ida e volta, aspectos, como, por exemplo, tamanho das trilhas disponíveis ou a complexidade do labirinto podem determinar o tempo necessário para convergência para a trilha, impondo um tempo maior para que esta ocorra.

Cabe também considerar se outros aspectos, como a presença de fontes de iluminação não difusas ou de umidificadores de ar na sala de experimentos, podem ser utilizados como referências. Os umidificadores de ar foram revezados de posição, podendo em algum momento ter produzido alguma resposta local que tenha impactado momentaneamente o fluxo de forma a impedir a ocorrência de uso da trilha mínima no tempo disponível. Porém, nenhum desses fatores introduz diretamente qualquer viés identificável para a formação dos caminhos observados, ou ainda a diferença na utilização dos caminhos de ida e volta. Também não parece ter havido uma interferência da presença prévia de trilhas no labirinto entre um experimento e o seguinte. A lavagem cuidadosa das trilhas após cada experimento e o intervalo de tempo entre as réplicas experimentais, às vezes realizadas com meses de diferença, e mesmo a sequência de realização das réplicas 
experimentais eliminam a hipótese de efeito de permanência da marcação feromonal entre experimentos diferentes. A ordem de realização dos experimentos (exp1, exp2, expc1, exp3, expc2) intercalou réplicas com folhas e controles, de forma que a não observação de preferências nos controles indica exatamente que a marcação do experimento anterior não estava presente e não poderia influenciar os resultados da réplica seguinte.

Com o objetivo de tornar a tarefa de deslocamento mais próxima de condições naturais, o labirinto utilizado foi propositalmente mais longo que os experimentos usuais encontrados na literatura, o que poderia dificultar a formação da trilha. Apesar disso impor dificuldades bastante relevantes, ele não pode ser considerado longo, dado que as formigas saúvas frequentemente fazem trilhas muito maiores na natureza (WEBER, 1972). Ainda assim, o labirinto apresenta dificuldades relevantes. Por exemplo, o uso de um dos caminhos mínimos possíveis apresenta a necessidade de que as formigas realizem uma série de alterações de direção e sentido. Para chegar à caixa com folhas, uma posição espacial que estaria 'acima', o indivíduo deve percorrer necessariamente um percurso para 'baixo'. Se um indivíduo na trilha 10 seguir o vetor global para as folhas, ele se desloca para a trilha 15 e não para a 11 que seria o sentido do caminho mínimo. Portanto, há nesse labirinto, conflitos entre a navegação por memorização de vetores globais e a navegação por marcação feromonal ou memorização de vetores locais. Dessa forma, é razoável que o labirinto seja um desafio real de navegação e que essa dificuldade possivelmente se reflita sobre a dispersão e formação de trilhas, dificultando a convergência para um caminho mínimo.

A dificuldade do labirinto que utilizamos expressa pelo número de bifurcações para ir da colônia às folhas é maior do que a dos labirintos comumente utilizados em alguns outros experimentos. Num labirinto em losângulo (GOSS et al., 1989), a trilha mais curta tem chance de 1:1 (uma mínima para uma longa). Na duplo losângulo é 1:3 (GOSS et al., 1989). Já no labirinto que utilizamos a chance era de 1:7 (duas mínimas para dezesseis longas). Além disso, dentre os caminhos possíveis para ir da colônia às folhas, o comprimento de caminho mais provável era o de sete trilhas e, de fato, esse foi o comprimento observado na ida de todos os experimentos com folhas. Embora a otimização tenha ocorrido em outros experimentos com labirintos ainda mais complexos (REID; SUMPTER; BEEKMAN, 2011), nestes casos foram utilizadas formigas Linepithema humile. Embora tanto em Atta quanto em Linepithema a marcação feromonal seja bastante relevante para determinação do 
comportamento nas trilhas de forrageamento (JAFFE et al., 1985; VON THIENEN et al., 2014) é importante notar que as formigas Linepithema marcam a trilha na ida também (DENEUBOURG et al., 1990b).

Não somente a estrutura do labirinto impõe desafios, mas o comportamento em si de dispersão parece, em alguma medida, reforçá-los. Nos experimentos controle, a probabilidade de ocorrência de caminhos cíclicos observada é maior do que a esperada segundo o modelo nulo. Tal efeito parece ser possivelmente associado à forma como o comportamento exploratório se estabelece, potencializando algumas das dificuldades apresentadas pelo labirinto ao evitar as conexões entre os anéis, aumentando a tendência das formigas percorrem trechos ciclicamente. Na medida em que antes do estabelecimento de uma trilha de forrageamento com corte e transporte de folhas houver um comportamento exploratório próximo ao observado, as fases iniciais de exploração do labirinto tendem a dificultar a otimização da dispersão.

Além dos aspectos da estrutura do labirinto, a variação do fluxo global pode eventualmente ter uma contribuição relevante para a não otimização tanto na ida quanto na volta. Para avaliar tal aspecto, as análises de entropia são bastante importantes, permitindo analisar os fluxos não apenas pelo seu valor absoluto, mas sua forma geral de ocorrência. Apesar do fluxo de um experimento variar ao longo do tempo aparentemente em ciclos, as entropias parecem, após uma fase inicial transiente, oscilar ao redor de algum patamar mais estável e próximo do modelo nulo. Sendo assim, na medida em que não foi observada uma correspondência entre o fluxo de um experimento e entropia da dispersão, é possível interpretar que nos momentos de menor fluxo, seja com um número menor de formigas, ou mesmo com formigas transitando pouco entre as caixas, a forma da dispersão não tenha recuado de fato, mantendo a sua conformação espacial. Dessa forma, é possível especular que o processo de formação de trilhas não tenha sido reduzido de forma consistente e, portanto, não tenha se iniciado novamente do zero, retendo a sua estrutura ou mantendo uma memória. Poderia-se esperar também que a retenção do padrão poderia se dar em algum grau em função das marcações feromonais anteriores, ainda ativas. Essa retenção da dispersão pode contribuir para uma menor flexibilidade na formação das trilhas ao longo do tempo observado. É possível que, em alguma medida, esse efeito seja provocado pelo fato de que as luzes não foram apagadas, de forma que um dos possíveis estímulos de retorno ao ninho não estivesse presente. 
Dado que nenhum experimento convergiu na ida e na volta pela mesma a trilha mínima, o modelo de forrageamento utilizado gerou uma distribuição muito destoante dos dados reais obtidos nos experimentos. Mesmo que se pudesse supor que tal incompatibilidade fosse esperada, dado que a convergência no modelo é muito alta, a amplitude desta incompatibilidade mostra a incapacidade do modelo prever os dados reais. Para sanar tal distinção, seria razoável tentar ajustar um modelo para convergir para uma solução sub ótima, ou ainda, para caminhos distintos de ida e volta. Contudo, uma vez que se trata de um algoritmo para solução de problemas de otimização combinatória, é difícil imaginar que estabilize no meio do gradiente. As soluções para problemas de otimização são pontos de mínimo ou máximos numa função e os algoritmos são elaborados para buscarem esses pontos. Por mais que se ajustasse os parâmetros do modelo de forma a não ter uma convergência muito intensa ou muito rápida, não seria garantido que houvesse maior probabilidade de convergência para soluções sub ótimas uma vez que essas são instáveis. Talvez para as formigas Linepithema os modelos sejam mais próximos do comportamento de fato observado nos experimentos uma vez que foram o modelo original (GOSS, 1989).

\subsection{Exploração Prévia}

É comum na literatura encontrar a solução do problema espacial posto pelo experimento somente quando há uma etapa de exploração livre do labirinto antes da etapa experimental em si (CAPALDI; ROBINSON; FAHRBACH, 1999; REID; SUMPTER; BEEKMAN, 2011). No caso das formigas, um dos argumentos é a possibilidade de uso de mais de um feromônio (DUSSUTOUR et al., 2009c; FOURCASSIÉ; DENEUBOURG, 1994; JACKSON; RATNIEKS, 2006; JEANSON; RATNIEKS; DENEUBOURG, 2003). Um deles, específico para forrageamento, produziria respostas mais intensas e seria mais volátil, ao passo que o outro seria um estímulo menos intenso e menos volátil, usado como uma marcação de área de vida (DEVIGNE; DETRAIN, 2002; SALZEMANN et al., 1992). Entretanto, não é claro como a marcação prévia com um feromônio mais geral, utilizado em qualquer trilha independentemente da posição do alimento, resolveria o problema de caminho mínimo da marcação seguinte, com um outro feromônio. 
Ainda assim, a possibilidade de uma exploração livre anterior à colocação de folhas seria um teste interessante. Porém, conforme observado pelas distâncias entre os modelos e os experimentos, a probabilidade de reconstrução da dispersão correspondente ao modelo de forrageamento a partir da dispersão produzida na exploração livre não é menor do que a partir da dispersão dos experimentos controle. Sendo assim, o conhecimento prévio não parece fornecer uma base de codificação do ambiente mais próxima da necessária para a solução do desafio posterior. Além disso, segundo a análise de probabilidade dos caminhos de forrageamento, os experimentos controle apresentam maior probabilidade de caminhos cíclicos do que o modelo nulo, sendo este intermediário ao dos experimentos com folhas e dos controles, e, portanto, mais uma vez os controles não estão mais próximos dos experimentos com folhas do que o modelo nulo. Sendo assim, os resultados observados permitem a proposição da hipótese de que a exploração prévia não favoreceria a convergência para a trilha mínima na ida e na volta.

\subsection{Comparação entre experimentos com folhas e controles}

Ao observarmos o comportamento nos experimentos controle, é possível perceber que não há fortes preferências em relação a caminhos específicos. Não só os fluxos nas trilhas e sentidos não se distanciam muito da média, mas especialmente no expc1, a convergência na ida e na volta não são diferentes do esperado segundo o modelo nulo. Em comparação, experimentos de exploração (DENEUBOURG et al., 1990; DETRAIN et al., 1991b; DEVIGNE; DETRAIN, 2002) comumente observam a formação de trilhas espontâneas em áreas abertas na ausência de alimento. Mesmo utilizando uma arena em que a colônia é central (PERNA et al., 2012), como no experimento apresentado, as formigas (Linepithema humili) exploraram a arena se dispersando uniformemente por todas as direções, mas logo formaram trilhas espontâneas que ao longo do tempo foram amplificadas ou abandonadas. A única semelhança deste com o caso do experimento apresentado nesse trabalho é a uniformidade na distribuição das saídas do ninho no caso do expc1, não sendo possível determinar se a ausência de trilhas preferenciais espontâneas se deve à diferença de espécies ou à estrutura do labirinto.

Outros aspectos dos controles que também chamam a atenção são as diferenças em relação ao modelo nulo. Primeiramente, os desvios em relação à média são menores 
nos controles do que no modelo nulo, o que sugere que o aspecto difusivo do modelo nulo talvez faça com que os fluxos diminuam rápido demais com a distância do ninho. Outra diferença é o baixo fluxo nos controles nas trilhas 4 e 7 . O baixo fluxo de retorno do anel externo para o anel interno poderia ser explicado pelo fato de haver preferência de uma formiga que está no anel externo pela trilha de menor ângulo em relação à sua direção original nas bifurcações 4 e 7, favorecendo que ela se mantenha no anel externo. Essa preferência é bastante coerente com o observado em outros experimentos (GARNIER et al., 2009; JACKSON; HOLCOMBE; RATNIEKS, 2004). Entretanto, as bifurcações de saída do anel interno para o externo são simétricas, e na medida em que há um favorecimento da manutenção do fluxo no primeiro anel, outro fator como a proximidade em relação à colônia seria necessário para justificar o baixo fluxo no sentido de saída. Independentemente do fator, a consequência de aumento da probabilidade de caminhos cíclicos, favorecendo a exploração 360o ao redor da colônia (REID; SUMPTER; BEEKMAN, 2011), é observada.

Somam-se à estes fatos outros dois, presentes tanto nos experimentos controle quanto nos com folhas. Um deles é o baixo fluxo nas trilhas 14 e 15 em relação ao modelo nulo. Apesar da proximidade da colônia, tanto em número de trilhas quanto em distância geométrica absoluta do ninho, e o fato de fecharem um ciclo de $360^{\circ}$ ao redor do ninho, seria razoável esperar um fluxo maior. Entretanto, na medida em que os fluxos nessas trilhas são sempre menores do que os das trilhas 3 e 5 , é possível que o fato destas serem conectadas às bifurcações leve a um aumento do fluxo. Dessa forma, a presença de trilhas que conectam a outras áreas mais distantes parece servir como um fator de atração do fluxo. Talvez, isso ocorra pela simples presença de mais formigas numa área de conexão (CZACZKES et al., 2015), do que numa área sem conexão à outras.

Nos experimentos com folhas, não só as variações em relação à média são maiores do que as observadas nos controles, mas a forma da dispersão é em si diferente. Apesar dessas diferenças não serem tão nítidas quando observadas ao longo do tempo de experimento possivelmente por conta de aspectos da dinâmica de formação das trilhas, na média é possível observar que as dispersões dos experimento com folhas são mais próximas entre si e do modelo de forrageamento, enquanto as dispersões dos controles são mais próximas entre si e do modelo nulo. Além disso, o fato de que no experimento parece haver uma concentração levemente maior de formigas no anel interno, ao passo que nos experimentos com folhas, o anel externo parece ter maior fluxo, sugere que aspectos como 
a proximidade da colônia e atração para as bifurcações sejam contextuais, dependendo da ausência de alimento e ou de trilhas de forrageamento. Na mesma medida, a presença de trilhas de forrageamento prevalece sobre o fluxo nas bifurcações do lado oposto ao preferido.

Comparando-se os experimentos com folhas e os controles via distâncias dos modelos, apesar de apresentarem pouca variação, a separação entre os grupos controle e com folhas é consistente. Isso revela que as diferenças entre experimentos parecem ter uma causa comportamental associada ao padrão de exploração e busca alimentar. Apesar da predominância do comportamento exploratório em todos eles, a diferença da dispersão experimental é provocada pelo comportamento de forrageamento por formação de trilhas. A alta intensidade da atividade exploratória provavelmente ocorre em função do alto número de indivíduos que tipicamente não participa diretamente das tarefas de corte e transporte (CHARBONNEAU et al., 2017; CHARBONNEAU; DORNHAUS, 2015; WILSON, 1983), mas que saem do ninho e eventualmente participam das trilhas. Uma vez que esses não têm necessidade de levar alimento de volta para a colônia, podem se dispersar com maior liberdade sem comprometer o forrageamento.

\subsection{Diferenças entre os caminhos preferenciais de ida e volta}

Outro aspecto bastante interessante nos resultados observados foi o fato de nos experimentos com folhas, o caminho de ida ser diferente do caminho de volta. Com maior ou menor convergência, o caminho preferencial de ida foi de sete trilhas de comprimento enquanto o de volta foi um de cinco (mínimo), partindo da caixa de folhas pelo lado oposto à chegada, de forma que todo o anel externo no sentido horário tenha sido utilizado por trilhas preferenciais. Além dos caminhos serem diferentes, a convergência no retorno foi sempre maior do que a convergência na ida do mesmo experimento.

Apesar de que, para qualquer caminho da colônia às folhas, a sequência de ângulos na perspectiva individual do retorno ser exatamente a sequência inversa da ida, o comportamento nas bifurcações é diferente em cada caso. Por exemplo, num caminho de 
ida, uma formiga na trilha 11 no sentido horário, encontra adiante uma bifurcação em que tanto a alternativa pela trilha 5 horária, ou pela trilha 7 horária, implicam desvios de $60^{\circ}$ do seu deslocamento original. Portanto, neste sentido de fluxo, a bifurcação da trilha 7 é simétrica. O mesmo ocorre se a formiga estiver originalmente na trilha 5 no sentido antihorário ao seguir pela trilha 11 no sentido anti-horário ou pela trilha 7 no sentido horário. No lado oposto, o mesmo ocorre com a bifurcação na trilha 4. Dessa forma, todas as possibilidades de saída do anel interno para o anel externo, assim como a manutenção do fluxo no anel interno, envolvem bifurcações simétricas. Por outro lado, uma formiga que retorne pela trilha 16 no sentido horário, encontra em sequência a possibilidade de virar $60^{\circ}$ horários e seguir pela trilha 6 no sentido horário, ou virar $120^{\circ}$ no sentido horário e seguir pela trilha 7 no sentido anti-horário. O mesmo ocorre com a bifurcação da trilha 4 . Sendo assim, no retorno ao anel interno e ao ninho, uma formiga se depara necessariamente com uma bifurcação assimétrica. Essa diferença entre a simetria na ida e na volta é chamada de polarização do âgulo.

No experimento realizado por Garnier (GARNIER et al., 2009), foram comparados os resultados obtidos no mesmo labirinto utilizado por Vittori (2006) e outro de mesma estrutura com bifurcações simétricas tanto na ida quanto na volta. Garnier observou uma maior probabilidade nos caminhos mínimos no labirinto assimétrico se comparado ao simétrico, o que corrobora a hipótese de que as assimetrias ajudam as formigas a se localizar no caminho de volta. Entretanto, em ambos os casos, nas bifurcações assimétricas de retorno, o caminho de menor ângulo sempre correspondia ao retorno de fato, ao passo que a opção de maior ângulo sempre levava à uma meia volta. Sendo assim, há em ambos experimentos (VITTORI et al., 2006; GARNIER et al., 2009) uma sobreposição dos efeitos da presença de bifurcações assimétricas no retorno e da preferência pelo menor ângulo.

Já no labirinto apresentado neste trabalho, no retorno, a adoção do caminho de maior ângulo é que corresponde ao retorno ao ninho. Ou seja, há, neste caso, um conflito entre a preferência pelo menor ângulo e o retorno ao ninho. Além disso, houve, nos experimentos com folhas, formação da trilha preferencial de volta num caminho mínimo. Esta trilha observada ([12h, 16h, 7ah, 11ah, 10ah]) partiu da caixa com folhas pelo lado oposto à chegada da trilha de ida, de modo que no anel externo a ida é diferente da volta. 
Embora seja esperado que ocorra a preferência pela trilha mínima, é, num primeiro momento, curioso que ela tenha partido pelo lado oposto. Entretanto, se partisse o retorno pela trilha mínima do mesmo lado da ida ([9ah, 8ah, 4ah, 1h, 13ah]), apesar do início comum com a ida estar marcado por feromônios, há necessariamente a sequência por trilhas não marcadas (trilha 4) justamente a partir do ponto em que há uma bifurcação assimétrica em que se deveria seguir pelo caminho de maior ângulo. Já o retorno contralateral observado nos experimentos ([12h, 16h, 7ah, 11ah, 10ah]), se junta ao início do caminho de ida justamente na bifurcação assimétrica (trilha 7), estando esta já marcada previamente e, na presença de feromônios, a preferência independe do ângulo (FORSTER et al., 2014). Sendo assim, uma vez que esteja ao menos parcialmente estabelecida a trilha de ida observada, a otimização na volta partindo pelo lado contralateral parece mais razoável uma vez que compartilha um trecho em comum já marcado que inclui as bifurcações e a saída do ninho já preferidas. Dessa forma, a presença da bifurcação assimétrica no ponto de encontro com a trilha de ida favorece a otimização do retorno pelo lado oposto ao da ida.

Dessa forma imagina-se que a ordem dos eventos se inicie com o estabelecimento de algum fluxo pelos caminhos mais prováveis segundo o modelo nulo (de comprimento sete). Enquanto ainda não houver marcação ou convergência muito intensas, estabelecemse parcialmente dois retornos diferentes: o inverso da ida preferencial [9ah, 8ah, 2ah, 6ah, 7ah, 11ah, 10ah], e o contralateral observado [12h, 16h, 7ah, 11ah, 10ah]. Por ser menor, o caminho contralateral de retorno tende a aumentar a intensidade da marcação mais rapidamente. Sendo assim, a trilha contralateral observada no retorno é favorecida em relação à trilha inversa de ida.

Uma vez compreendido que a otimização no retorno é mais provável pelo caminho contralateral ao de ida, resta compreender por quê a ida se mantém pelo caminho de sete trilhas. $\mathrm{Na}$ ida, diante do fato de que a trilha original seguia pela trilha 6 no sentido horário e um novo retorno inicia-se posteriormente pela trilha 16 no sentido horário, num dado momento as duas possibilidades de ida estão parcialmente marcadas. Ao contrário do retorno, na ida essa bifurcação é simétrica, ou seja, os ângulo em si não induzem uma preferência. Entretanto, dado que o caminho original seguia pela trilha 6 , é possível que essa via tenha sido memorizada a ponto do seu favorecimento ser mantido. Contudo, se o caminho de ida a partir da trilha 6 não for reforçado, com o passar do tempo, a opção pela via memorizada é mantida em detrimento da marcação feromonal. Há situações em que a 
memória individual poderia se sobrepor à marcação feromonal (GRÜTER; CZACZKES; RATNIEKS, 2010). Se houver reforço, ou ainda, marcação na ida também, o caminho original pode ter uma marcação parecida com o de volta e ainda ter a vantagem de ser o que as formigas o memorizaram. Outra possibilidade, é que tanto a marcação da trilha original quanto do retorno contralateral tenham atingido um nível de saturação a partir do qual as formigas não distinguam entre as opções. Nesses cenários de reforço de marcação ou saturação, também prevaleceria a memória individual do caminho original. Ainda assim, dado que a memorização da ida é crítica, parece ainda curioso que no caminho de volta a memória não seja integrada ou sobrescrita dado que a bifurcação é a mesma. Entretanto, foi observado que as memórias são específicas para o contexto (ida ou volta) em que foram formadas (WEHNER et al., 2006), de forma que é razoável que não haja na volta uma reassociação de uma memória formada na ida e vice-e-versa.

O fato observado é que o arranjo do labirinto favorece a formação de caminhos de sete trilhas de comprimento e estas favorecem a otimização no retorno pelo caminho que parte do alimento pelo lado oposto. Isso ocorre por conta do fato de que o retorno reencontra o caminho de ida precisamente no ponto crítico em que há uma bifurcação assimétrica, de forma que a marcação feromonal previamente existente favoreça a escolha pelo maior ângulo. Sendo assim, a estrutura do labirinto favorece a formação de um novo retorno necessariamente oposto no anel externo à ida, provocando uma separação dos dois fluxos.

A separação das trilhas de ida e volta já foi anteriormente observada em trilhas de formigas saúvas (RIBEIRO et al., 2009). Porém ocorria num contexto em que a separação era a única possibilidade de estabelecimento de fluxo no labirinto, porque as trilhas eram verticais e tinham lacunas que permitiam somente que uma formiga se soltasse e caísse, mas impossibilitavam que ela subisse de volta. Há algumas semelhanças entre os dois casos. No caso apresentado por Ribeiro (2009), a formação de trilhas com corte e transporte de folhas nessa condição levou entre dois e três dias, sendo que a solução se deu gradualmente. No caso apresentado neste trabalho, apesar da formação da trilha ter sido mais rápida dado que separação não era crítica, a otimização no retorno com separação entre a ida e a volta foi gradual. Entre as diferenças, vale destacar que conforme posto por Ribeiro, as formigas deveriam 'desligar' os seus outros mecanismos de orientação e priorizar a memória individual para chegarem ao caminho correto de volta, ao passo que 
neste experimento os mecanismos de orientação espacial, como o comportamento diante das assimetrias das bifurcações, participam da separação dos caminhos, e, portanto, não foram 'desligados'.

Outra observação interessante apontada por Ribeiro (2009) é que o comportamento de retorno ao ninho a partir da fonte de alimento não é estereotipado. Pelo contrário, ele é flexível o suficiente para que uma formiga se desloque no sentido oposto. Essa flexibilidade do comportamento de retorno é corroborada neste experimento. Além disso, Ribeiro (2009) observou que a orientação segundo a luz parece cumprir um papel importante a medida que no escuro as formigas não solucionavam a tarefa, ou reduziam o desempenho se já tivessem resolvido previamente. A inversão da posição da fonte luminosa também provocava uma queda de desempenho. Dessa forma, a solução parece depender da aprendizagem da resposta de não inversão do deslocamento em relação à posição da luz no início do retorno. Diante dessa observação, parece interessante testar o desempenho das formigas no labirinto apresentado neste trabalho no escuro e também com a inversão da posição da luz em relação aos ângulos das bifurcações assimétricas.

Há ainda outras hipóteses. Se houver alguma forma de polarização na marcação feromonal, há a possibilidade de separação dos fluxos de ida e volta. Ainda haveria a possibilidade de que o feromônio utilizado na ida fosse diferente do utilizado na volta. $O$ feromônio utilizado na ida, inclusive se utilizado no início da exploração do labirinto, poderia ser de marcação territorial, conforme observado por Salzemann (1992), diferentemente da volta, em que haveria marcação com feromônio de forrageamento. Entretanto, não há evidências comportamentais da existência de polarização na marcação das trilhas (CZACZKES; GRÜTER; RATNIEKS, 2015; WETTERER et al., 1992).

\subsection{Exploração e forrageamento}

Além da questão da determinação das trilhas preferenciais, a utilização dessas ocorre segundo algum grau de convergência. No caso, o segundo experimento com folhas (exp2) foi o que apresentou maior convergência. Apesar da baixa convergência dos outros experimentos, elas ainda foram maiores do que as observadas nos experimentos controle. $A$ baixa convergência indica que, apesar da formação do fluxo preferencial em função do 
forrageamento, parte significativa da dispersão se deve à movimentação exploratória pelo labirinto. Quanto menor a convergência, maior tende a ser a entropia informacional das dispersões. Dado que todos os experimentos com folhas convergiram para as mesmas trilhas preferenciais, a variação da entropia entre eles se deve às diferenças entre os grau de convergência.

A separação dos caminhos de ida e volta faz com que a dispersão ocupe um número maior de trilhas do que ocuparia caso ida e volta fossem exatamente inversas. Consequentemente, a separação dificulta a visualização das diferenças entre os experimentos, fazendo com que a entropia dos experimentos com folhas se aproxime dos controles e do modelo nulo. Ainda assim, através das medidas dadas pelas entropias cruzadas entre as distribuições observadas e os modelos de referência, é possível distinguir os experimentos com folhas e sem folhas em função dos comportamentos subjacentes. A comparação utilizando a entropia cruzada leva em consideração quais são as diferenças específicas entre as distribuições, garantindo maior sensibilidade na comparação com os modelos do que a comparação direta entre os valores de entropia calculados separadamente.

Uma forma possível de avaliação adicional do comportamento seria observar medidas diretas de forrageamento. Há algumas formas diferentes de se realizar essas medidas. Uma, seria pesar a massa das folhas antes de serem colocadas no labirinto e depois de retiradas. Nesse caso, a mesma massa de folhas poderia ser colocada ao lado da caixa, externamente ao labirinto, para que se pudesse calcular a redução da massa dada pela desidratação. Outra possibilidade é identificar formigas transportadoras através da análise das imagens. Essa alternativa é particularmente interessante por não necessitar de nova coleta de dados. A reanálise dos vídeos já obtidos poderia medir qual o fluxo de formigas transportadoras. Do ponto de vista técnico, há uma variedade de classificadores capazes de fazer a distinção. As redes neurais profundas (deep learning) são o estado da arte nesse tipo de tarefa e ainda tem a grande vantagem de que a incorporação dessa classificação na detecção de formigas, conforme a que foi testada, ser bastante simples. A maior dificuldade seria anotar manualmente as formigas transportadoras, embora após a presente análise dos resultados seja mais fácil por se saber em que trilhas encontrá-las. 
Vale observar que diante do conflito entre exploração e forrageamento, a separação entre os fluxos de ida e volta mantém uma dispersão maior sobre o labirinto ao mesmo tempo que forma uma trilha de forrageamento funcional operando segundo os mecanismos de marcação feromonal, sendo uma estratégia particularmente interessante de lidar com o desafio. Embora seja razoável que os indivíduos respondam à elementos particulares como marcação feromonal, ângulos de bifurcação e memória, as questões coletivas como o balanço entre exploração e forrageamento são importantes na medida em que o comprometimento de uma delas pode afetar criticamente a viabilidade das formas de resposta no nível individual e mesmo de trilhas adotadas (HILLS, 2014).

Aliás, uma vez que o fitness inclusivo se dá mais em função do sucesso da colônia do que do sucesso de um indivíduo, os aspectos coletivos são determinantes. Mesmo em situações em que não há uma socialidade completa, como no caso de cardumes de peixes, foi observado (SCHNELL et al., 2013) que através das regras de deslocamento dadas pela interação entre os indivíduos, os peixes eram capazes de se manter mais tempo ao abrigo da luz num ambiente com um gradiente de iluminação quando em grupos do que quando sozinhos ou em poucos. Isso ocorre porque enquanto um indivíduo é somente capaz de responder à iluminação específica da sua posição, coletivamente, respondendo às interações, eles são capazes de perceber o gradiente ambiental e explorá-lo de forma a obter um melhor resultado global, funcionando como um sentido coletivo. No caso das formigas, são conhecidas diversas formas de interação e mecanismos individuais bem como os impactos coletivos, entretanto são observados em termos de eficiência direta, sendo raramente interpretados como uma forma de integração perceptiva do espaço e seus desafios. 
9. Conclusões 
Nas três réplicas experimentais com folhas foi possível observar um mesmo padrão de utilização do labirinto em que as formigas estabeleceram trilhas de retorno à colônia parcialmente diferentes das trilhas estabelecidas na ida às folhas. No retorno, as formigas deixaram a caixa das folhas pelo lado oposto ao da trilha de chegada, seguindo por um caminho contralateral ao realizado na ida. $\mathrm{Na}$ bifurcação de retorno ao anel interno do labirinto, onde há uma bifurcação assimétrica, o caminho de retorno contralateral reencontra o caminho de ida. Dada a estrutura do labirinto, o estabelecimento do retorno contralateral ao caminho de ida é favorecido por reencontrar o caminho de ida numa bifurcação assimétrica, e por ser uma otimização do caminho de volta.

O caminho de retorno utilizado, diferentemente do caminho de ida, é o caminho de menor comprimento. Sendo assim, a otimização observada nos experimentos controle foi parcial. Diante da ampla literatura à respeito da capacidade de otimização das trilhas segundo o mecanismo de marcação feromonal, a não ocorrência neste experimento indica a relevância da integração de outros mecanismos de orientação que atuam conjuntamente à marcação feromonal.

Apesar da separação dos caminhos de ida e volta de uma mesma trilha já ter sido observada anteriormente uma única vez em formigas saúvas (Ribeiro, 2009), ela ocorreu somente em condições em que a separação era forçada, sendo a única forma possível de estabelecimento de uma trilha de forrageamento. Já no trabalho apresentado, as colônias poderiam manter o fluxo bidirecional nas trilhas. Sendo assim, o labirinto proposto foi capaz de promover a separação conflitando os mecanismos de orientação por marcação de trilhas com os mecanismos de orientação por preferências angulares individuais e de memória individual, além da própria capacidade de otimização, segundo o mecanismo de marcação feromonal;

Além disso, foi observado que a dispersão observada nos experimentos com folhas foi bastante diferente da dispersão simulada segundo o modelo teórico utilizado de formação de trilhas de forrageamento. Primeiramente pelo fato de que o modelo não produz a separação dos caminhos de ida e volta. Mesmo porque, no modelo, o comportamento de uma formiga no retorno ao ninho é deterministicamente dado pelo inverso do caminho realizado na ida. $E$ também porque a dispersão observada experimentalmente para além da 
utilização das trilhas preferenciais foi maior do que a observada nas simulações. Sendo assim, o modelo não foi capaz de descrever a variação presente para além do efeito de convergência das trilhas.

A dispersão observada nos experimentos controle também foi diferente da observada no modelo de exploração livre. No modelo o fluxo no anel interno é muito maior do que no anel externo, e o fluxo em cada trilha depende diretamente da distância desta em relação à colônia. Já nos experimentos controles, as trilhas do anel externo apresentam um fluxo somente um pouco menos intenso do que o fluxo no anel interno. Além disso, as trilhas mais próximas das conexões entre os anéis apresentam fluxo mais intenso do que as mais distantes das conexões. Embora o fluxo nas conexões tenha sido muito menor nos experimentos do que no modelo nulo de exploração livre.

Tanto o favorecimento da separação dos caminhos de ida e volta com otimização a partir do retorno contralateral quanto o baixo fluxo nas conexões entre os anéis nos experimentos controles são efeitos característicos das preferências angulares individuais, de preferência pela trilha de menor desvio em relação à direção original de deslocamento. Além disso, o papel da memória individual pode ser determinante na manutenção do caminho de ida nos experimentos com folhas. Dessa forma, tanto por conta da presença de bifurcações assimétricas quanto pelo comportamento de persistência no caminho de ida pode-se observar a influência de fatores individuais na dispersão coletiva pelo labirinto. Esses fatores parecem ser importantes para descrever de forma causal a dispersão para além da trilha preferencial que o modelo teórico de forrageamento não é capaz de reproduzir.

Comparando-se as dispersões observadas nos experimentos com folhas, nos controles e nos modelos de forma a se levar em conta a estrutura do labirinto foi possível observar que as dispersões dos experimentos com folhas são muito mais parecidas entre si e com o modelo de forrageamento. Observou-se também que os controles e o modelo de exploração livre são mais parecidos entre si. Sendo assim, levando-se em conta a estrutura do labirinto, as diferenças entre as dispersões parecem ser consequência dos comportamentos subjacentes de forrageamento e exploração livre. 
Quando comparadas as dispersões e os modelos segundo características globais da dispersão, no caso a entropia informacional de Shannon, os modelos seguem o comportamento esperado de uma maior entropia no modelo de exploração nula e menor no modelo de forrageamento. Sendo assim, os modelos funcionaram respectivamente como limites superior e inferior, delimitando o resultados possíveis no gradiente de dispersão, representando os casos em que a totalidade da dispersão é dada exclusivamente por um dos comportamentos. As entropias dos experimentos apresentaram valores mais próximos do modelo de exploração livre do que do modelo de forrageamento. O fato das dispersões observadas experimentalmente ser sempre maior do que nos modelos e a separação entre o caminho de ida e de volta, ambos os fatores contribuem para a dispersão global se aproximar mais do comportamento exploratório do que de forrageamento.

Ainda assim, quando realizadas as comparações partindo-se de uma das dispersões dos modelos, utilizando-se a entropia cruzada, os experimentos com folhas são as menos divergentes da dispersão do modelo de forrageamento, ao passo que as dispersões dos controles são as menos divergentes da dispersão do modelo de exploração livre. Em conjunto, as comparações globais utilizando a entropia informacional de Shannon e as comparações em pares, utilizando a entropia cruzada, apontam que os comportamentos subjacentes de forrageamento e exploração produzem maiores diferenças específicas, em pontos localizados do labirinto, não produzindo nas dispersões diferenças globais tão marcantes. 


\section{Referências Bibliográficas}

AGARWAL, G. et al. Spatially Distributed Local Fields in the Hippocampus Encode Rat Position. Science, v. 344, n. 6184, p. 626-630, 2014.

ANDERSEN, P.; HOLMQVIST, B.; VOORHOEVE, P. E. Entorhinal Activation of Dentate Granule Cells. Acta Physiologica Scandinavica, v. 66, n. 4, p. 448-460, abr. 1966.

AUTUORI, M. Contribuição para o conhecimento da saúva (Atta spp.: Hymenoptera: Formicidae). V Número de formas aladas e redução dos sauveiros iniciais. Arquivos do Instituto Biológico de São Paulo, v. 19, p. 325-331, 1950.

BARBOSA, H. J. C. et al. Ant colony optimization - techniques and applications. [s.l: s.n.].

BARNICH, O.; VAN DROOGENBROECK, M. ViBe: A Universal Background Subtraction Algorithm for Video Sequences. IEEE Transactions on Image Processing, v. 20, n. 6, p. 1709-1724, jun. 2011.

BENHAMOU, S.; POUCET, B. A comparative analysis of spatial memory processes. Behavioural Processes, v. 35, n. 1-3, p. 113-126, dez. 1995.

BESHERS, S. N.; FEWELL, J. H. Models Of Division Of Labor In Social Insects. Annual Review of Entomology, v. 46, n. 1, p. 413-440, jan. 2001.

BLISS, T. V. P.; LØMO, T. Long-lasting potentiation of synaptic transmission in the dentate area of the anaesthetized rabbit following stimulation of the perforant path. The Journal of Physiology, v. 232, n. 2, p. 331-356, 1 jul. 1973.

BONABEAU, E. et al. Self-organization in social insects. Trends in Ecology \& Evolution, v. 12, n. 5, p. 188-193, maio 1997.

BONABEAU, E. Fixed Response Thresholds and the Regulation of Division of Labor in Insect Societies. Bulletin of Mathematical Biology, v. 60, n. 4, p. 753-807, jul. 1998.

BONABEAU, E.; THERAULAZ, G.; DENEUBOURG, J.-L. Quantitative Study of the Fixed Threshold Model for the Regulation of Division of Labour in Insect Societies. Proceedings of the Royal Society B: Biological Sciences, v. 263, n. 1376, p. 1565-1569, 22 nov. 1996.

BONNET, C. Observations sur de petites Fourmis qui s' etoient établies dans la tête d'un chardon à bonnetier. In: Oeuvres d'Histoire Naturelle et de Philosophie Neuchatel I. [s.l: s.n.]. p. 523.

BORGMEIER, T. Revision der Gattung Atta Fabricius (Hymenoptera, Formicidae). Studia, 1959.

BOTTINELLI, A. et al. Local cost minimization in ant transport networks: from small-scale data to large-scale trade-offs. Journal of The Royal Society Interface, v. 12, n. 112, p. 20150780, 2015.

BOURGEOIS, F.; LASSALLE, J.-C. An extension of the Munkres algorithm for the assignment problem to rectangular matrices. Communications of the ACM, v. 14, n. 12, p. 802-804, 1 dez. 1971.

BRADSKI, G. The OpenCV Library. Dr Dobbs Journal of Software Tools, v. 25, n. 11, p. 120-126, 2000. 
BUZSAKI, G. Our skewed sense of space. Science, v. 347, n. 6222, p. 612-613, 2015.

CAMAZINE, S. Self-organization in biological systems. [s.I.] Princeton University Press, 2003.

CANNON, W. Organization for Physiological Homeostasis. Physiological Reviews, v. IX, n. 3, p. 399-431, 1929.

CAPALDI, E. A.; ROBINSON, G. E.; FAHRBACH, S. E. Neuroethology of spatial learning: the birds and the bees. Annual review of psychology, v. 50, p. 651-682, 1999.

CARTWRIGHT, B. A.; COLLETT, T. S. Landmark learning in bees. Journal of Comparative Physiology A, v. 151, n. 4, p. 521-543, 1983.

CHARBONNEAU, D. et al. Who Are the "Lazy" Ants? The Function of Inactivity in Social Insects and a Possible Role of Constraint: Inactive Ants Are Corpulent and May Be Young and/or Selfish.

Integrative and comparative biology, v. 57, n. 3, p. 649-667, 2017.

CHARBONNEAU, D.; DORNHAUS, A. When doing nothing is something. How task allocation strategies compromise between flexibility, efficiency, and inactive agents. Journal of Bioeconomics, v. 17, n. 3, p. 217-242, 2015.

CHENG, K. et al. Traveling in clutter: Navigation in the Central Australian desert ant Melophorus bagoti. Behavioural Processes, v. 80, n. 3, p. 261-268, 2009.

COLLETT, M. et al. Local and global vectors in desert ant navigation. Nature, v. 394, n. 6690, p. 269272, 1998.

COLLETT, M.; CHITTKA, L.; COLLETT, T. S. Spatial memory in insect navigation. Current Biology, v. 23, n. 17, p. R789-R800, 2013.

COLLETT, M.; COLLETT, T. S. How do insects use path integration for their navigation? Biological Cybernetics, v. 83, n. 3, p. 245-259, 2000.

COLLETT, M.; COLLETT, T. S. Insect Navigation: No Map at the End of the Trail? Current Biology, v. 16, n. 2, p. R48-R51, jan. 2006.

COLLETT, M.; COLLETT, T. S. Local and global navigational coordinate systems in desert ants. The Journal of experimental biology, v. 212, n. 7, p. 901-5, abr. 2009.

COLLETT, T. S. et al. Visual landmarks and route following in desert ants. Journal of Comparative Physiology A, v. 170, n. 4, p. 435-442, 1992.

COLLETT, T. S.; COLLETT, M.; WEHNER, R. The guidance of desert ants by extended landmarks. The Journal of experimental biology, v. 204, n. Pt 9, p. 1635-9, maio 2001.

CORKIN, S. TIMELINEWhat's new with the amnesic patient H.M.? Nature Reviews Neuroscience, v. 3, n. 2, p. 153-160, 1 fev. 2002.

COUZIN, I. D. et al. Collective memory and spatial sorting in animal groups. Journal of theoretical biology, v. 218, n. 1, p. 1-11, 2002.

COUZIN, I. D. Collective cognition in animal groups. Trends in cognitive sciences, v. 13, n. 1, p. 3643, jan. 2009.

CZACZKES, T. J. et al. Ant foraging on complex trails: route learning and the role of trail pheromones in Lasius niger. Journal of Experimental Biology, p. 188-197, 2012. 
CZACZKES, T. J. How to not get stuck-Negative feedback due to crowding maintains flexibility in ant foraging. Journal of Theoretical Biology, v. 360, p. 172-180, 2014.

CZACZKES, T. J. et al. Perception of collective path use affects path selection in ants. Animal Behaviour, v. 99, p. 15-24, jan. 2015.

CZACZKES, T. J.; GRÜTER, C.; RATNIEKS, F. L. W. Trail Pheromones: An Integrative View of Their Role in Social Insect Colony Organization. Annual Review of Entomology, v. 60, n. 1, p. 581-599, 2015.

DARWIN, C. Objections To The Theory Of Natural Selection As Applied To Instincts: Neuter And Sterile Insects. In: The Origin of Species by means of Natural Selection, 6th Edition by Charles Darwin. 6th. ed. [s.l: s.n.].

DELLA LUCIA, T. M. C. As formigas cortadeiras. [s.I.] Sociedade de Investigadores Florestais, 1993. 262p., 1993.

DENEUBOURG, J. L. et al. The self-organizing exploratory pattern of the argentine ant. Journal of Insect Behavior, v. 3, n. 2, p. 159-168, 1990a.

DENEUBOURG, J. L. et al. The self-organizing exploratory pattern of the argentine ant. Journal of Insect Behavior, v. 3, n. 2, p. 159-168, 1990b.

DETRAIN, C. et al. Dynamics of Collective Exploration in the Ant Pheidole Pallidula. Psyche: A Journal of Entomology, v. 98, n. 1, p. 21-31, 1991.

DEVIGNE, C.; DETRAIN, C. Collective exploration and area marking in the ant Lasius niger. Insectes Sociaux, v. 49, n. 4, p. 357-362, 2002.

DORIGO, M.; DI CARO, G. The Ant Colony Optimization Meta-Heuristic. New Ideas in Optimization, v. 2, p. 11-32, 1999.

DORIGO, M.; MANIEZZO, V.; COLORNI, A. Ant system: optimization by a colony of cooperating agents. IEEE transactions on systems, man, and cybernetics. Part B, Cybernetics : a publication of the IEEE Systems, Man, and Cybernetics Society, v. 26, n. 1, p. 29-41, jan. 1996.

DORIGO, M.; STÜTZLE, T. Ant Colony Optimization. Scituate, MA, USA: Bradford Company, 2004.

DORNHAUS, A.; FRANKS, N. R. Individual and collective cognition in ants and other insects (Hymenoptera: Formicidae). Myrmecological News, v. 11, n. August, p. 215-226, 2008.

DUSSUTOUR, A. et al. Individual and collective problem-solving in a foraging context in the leafcutting ant Atta colombica. Animal Cognition, v. 12, n. 1, p. 21-30, 17 jan. $2009 a$.

DUSSUTOUR, A. et al. Priority rules govern the organization of traffic on foraging trails under crowding conditions in the leaf-cutting ant Atta colombica. The Journal of experimental biology, $\mathrm{v}$. 212 , n. 4 , p. $499-505$, fev. 2009b.

DUSSUTOUR, A. et al. The role of multiple pheromones in food recruitment by ants. The Journal of experimental biology, v. 212, n. Pt 15, p. 2337-48, ago. 2009c.

DUSSUTOUR, A.; DENEUBOURG, J.-L.; FOURCASSIÉ, V. Amplification of individual preferences in a social context: the case of wall-following in ants. Proceedings. Biological sciences I The Royal Society, v. 272, n. 1564, p. 705-714, 2005.

FARRIS, S. M. Evolution of insect mushroom bodies: Old clues, new insights. Arthropod Structure and Development, v. 34, n. 3, p. 211-234, 2005. 
FARRIS, S. M. Insect societies and the social brain. Current Opinion in Insect Science, v. 15, p. 18, 2016.

FERBINTEANU, J.; SHAPIRO, M. L. Prospective and retrospective memory coding in the hippocampus. Neuron, v. 40, n. 6, p. 1227-1239, 2003.

FOURCASSIÉ, V.; DENEUBOURG, J. L. The dynamics of collective exploration and trail-formation in Monomorium pharaonis: experiments and model. Physiological Entomology, v. 19, n. 4, p. 291300, dez. 1994.

GARNIER, S. et al. Path selection and foraging efficiency in Argentine ant transport networks.

Behavioral Ecology and Sociobiology, v. 63, n. 8, p. 1167-1179, 24 mar. 2009.

GOLDSCHMIDT, D.; MANOONPONG, P.; DASGUPTA, S. A Neurocomputational Model of GoalDirected Navigation in Insect-Inspired Artificial Agents. Frontiers in Neurorobotics, v. 11, n. April, p. 1-17, 2017.

GORDON, D. The organization of work in social insect colonies. Complexity, v. 8, n. 1, p. 43-46, 2002.

GORDON, D. M. The organization of work in social insect colonies. Nature, v. 380, n. 6570, p. 121124, set. 1996.

GORDON, D. M. The ecology of collective behavior. PLoS biology, v. 12, n. 3, p. e1001805, mar. 2014.

GOSS, S. et al. Self-organized shortcuts in the Argentine ant. Naturwissenschaften, v. 76, n. 12, p. 579-581, 1989.

GRÜTER, C.; CZACZKES, T. J.; RATNIEKS, F. L. W. Decision making in ant foragers (Lasius niger) facing conflicting private and social information. Behavioral Ecology and Sociobiology, p. 141-148, jul. 2010a.

GRÜTER, C.; CZACZKES, T. J.; RATNIEKS, F. L. W. Decision making in ant foragers (Lasius niger) facing conflicting private and social information. Behavioral Ecology and Sociobiology, v. 65, n. 2, p. 141-148, 20 jul. 2010b.

GUPTA, S. et al. Defining structural homology between the mammalian and avian hippocampus through conserved gene expression patterns observed in the chick embryo. Developmental Biology, v. 366, n. 2, p. 125-141, 2012.

HAFTING, T. et al. Microstructure of a spatial map in the entorhinal cortex. Nature, v. 436, n. 7052, p. 801-806, 2005.

HAMILTON, W. D. The genetical evolution of social behaviour. I. Journal of theoretical biology, v. 7, n. 1, p. 1-16, jul. 1964a.

HAMILTON, W. D. The genetical evolution of social behaviour. II. Journal of theoretical biology, v. 7, n. 1, p. 17-52, jul. 1964b.

HELENE, A. F.; XAVIER, G. F. Memória e (a elaboração da) percepção imaginação inconsciente e consciêncialntersecções entre psicologia e neurociências, 2007.

HEYMAN, Y. et al. Ants regulate colony spatial organization using multiple chemical road-signs.

Nature Communications, v. 8, p. 1-11, 2017. 
HILLS, T. T. et al. Exploration versus exploitation in space, mind, and society. Trends in Cognitive Sciences, v. 19, n. 1, 2014.

HOFSTADTER, D. H. Gödel, Escher, Bach: An Eternal Golden Braid;[a Metaphoric Fugue on Minds and Machines in the Spirit of Lewis Carroll]. 1. ed. [s.I.] Books, Basic, 1979.

JACKSON, D. E.; HOLCOMBE, M.; RATNIEKS, F. L. W. Trail geometry gives polarity to ant foraging networks. Nature, v. 432, n. 7019, p. 907-909, 2004.

JACKSON, D. E.; RATNIEKS, F. L. W. Communication in ants. Current Biology, v. 16, n. 15, p. 570$574,2006$.

JAFFE, K.; DENEUBOURG, J. L. On foraging, recruitment systems and optimum number of scouts in eusocial colonies. Insectes Sociaux, v. 39, n. 2, p. 201-213, jun. 1992.

JAFFE, K.; HOWSE, P. E. The mass recruitment system of the leaf cutting ant, Atta cephalotes (L.). Animal Behaviour, v. 27, n. PART 3, p. 930-939, 1979.

JAYADEVA et al. Ants find the shortest path: A mathematical proof. Swarm Intelligence, v. 7, n. 1, p. 43-62, 2013.

JEANSON, R.; DUSSUTOUR, A.; FOURCASSIÉ, V. Key factors for the emergence of collective decision in invertebrates. Frontiers in neuroscience, v. 6, n. August, p. 121, jan. 2012.

JEANSON, R.; RATNIEKS, F. L. W.; DENEUBOURG, J.-L. Pheromone trail decay rates on different substrates in the Pharaoh's ant, Monomorium pharaonis. Physiological Entomology, v. 28, n. 3, p. 192-198, set. 2003.

JOHNSON, B. R. et al. Phylogenomics resolves evolutionary relationships among ants, bees, and wasps. Current Biology, v. 23, n. 20, p. 2058-2062, 2013.

JONES, E. G. Santiago Ramón y Cajal and the croonian lecture, March 1894. Trends in Neurosciences, v. 17, n. 5, p. 192-193, jan. 1994.

LATTY, T.; BEEKMAN, M. Keeping track of changes: The performance of ant colonies in dynamic environments. Animal Behaviour, v. 85, n. 3, p. 637-643, 2013.

LEVER, C. et al. Boundary Vector Cells in the Subiculum of the Hippocampal Formation. Journal of Neuroscience, v. 29, n. 31, p. 9771-9777, 2009.

LI, X. R.; LI, N.; JILKOV, V. P. SPRT-based track confirmation and rejection. In: Information Fusion, 2002. Proceedings of the Fifth International Conference on. [s.I: s.n.]. v. 2p. 951-958.

LOMO, T. The discovery of long-term potentiation. Philosophical Transactions of the Royal Society B: Biological Sciences, v. 358, n. 1432, p. 617-620, 2003.

LØMO, T. Discovering long-term potentiation (LTP) - recollections and reflections on what came after. Acta Physiologica, v. 222, n. 2, p. 1-22, 2018.

MACGREGOR, E. G.; THORPE, W. H. Odour as a Basis for Orientated Movement in Ants. Behaviour, v. 1, n. 3, p. 267-296, 1948.

MAGEE, J. C.; JOHNSTON, D. A synaptically controlled, associative signal for Hebbian plasticity in hippocampal neurons. Science (New York, N.Y.), v. 275, n. 5297, p. 209-13, 10 jan. 1997.

MARCO DORIGO, MAURO BIRATTARI, T. S. Ant Colony Optimization . A Computational Intelligence Technique. IEEE Computational Intelligence Magazine, v. 1, n. 4, p. 28-39, 2006. 
MARICONI, F. A. M. As saúvas. [s.I.] Agronômica Ceres São Paulo, 1970.

MENZEL, R. Searching for the Memory Trace in a Mini-Brain, the Honeybee. Learning \& Memory, v. 8, n. 2, p. 53-62, 1 mar. 2001.

MENZEL, R. et al. Honey bees navigate according to a map-like spatial memory. Proceedings of the National Academy of Sciences of the United States of America, v. 102, n. 8, p. 3040-5, 22 fev. 2005.

MENZEL, R.; BENJAMIN, P. Invertebrate learning and memory. [s.I.] Academic Press, 2013. v. 22

MENZEL, R.; GREGGERS, U. The memory structure of navigation in honeybees. Journal of Comparative Physiology A: Neuroethology, Sensory, Neural, and Behavioral Physiology, v. 201, n. 6, p. 547-561, 2015.

MENZEL, R.; MULLER, U. Learning and memory in honeybees: from behavior to neural substrates. Annual review of neuroscience, v. 19, p. 379-404, jan. 1996.

MERSCH, D. P.; CRESPI, A.; KELLER, L. Tracking individuals shows spatial fidelity is a key regulator of ant social organization. Science, v. 340, n. 6136, p. 1090-3, 2013.

MILAN, A. et al. MOT16: A Benchmark for Multi-Object Tracking. p. 1-12, 2016.

MIZUNAMI, M.; WEIBRECHT, J. M.; STRAUSFELD, N. J. Mushroom bodies of the cockroach: Their participation in place memory. Journal of Comparative Neurology, v. 402, n. 4, p. 520-537, 1998.

MORRIS, R. G. et al. Place navigation impaired in rats with hippocampal lesions.Nature, 1982.

MULLER, M.; R. WEHNER. Path integration in desert ants, Cataglyphis fortis. Proceedings of the National Academy of Sciences, v. 85, n. 14, p. 5287-5290, 1988.

NARENDRA, A. Homing strategies of the Australian desert ant Melophorus bagoti I. Proportional pathintegration takes the ant half-way home. Journal of Experimental Biology, v. 210, n. 10, p. 17981803, 2007a.

NARENDRA, A. Homing strategies of the Australian desert ant Melophorus bagoti II. Interaction of the path integrator with visual cue information. Journal of Experimental Biology, v. 210, n. 10, p. 18041812, 2007b.

NIEDFELDT, P. C.; BEARD, R. W. Multiple target tracking using recursive RANSAC. 2014 American Control Conference. Anais...IEEE, jun. 2014Disponível em:

<http://ieeexplore.ieee.org//pdocs/epic03/wrapper.htm?arnumber=6859273>

O'KEEFE, J. Place units in the hippocampus of the freely moving rat. Experimental Neurology, v. 51, n. 1, p. 78-109, jan. 1976.

O'KEEFE, J.; CONWAY, D. H. Brain Hippocampal Place Units in the Freely Moving Rat: Why They Fire Where They Fire. Experimental Brain Research, v. 31, n. 4, p. 573-590, 1978.

O'KEEFE, J.; DOSTROVSKY, J. The hippocampus as a spatial map. Preliminary evidence from unit activity in the freely-moving rat. Brain research, v. 34, n. 1, p. 171-175, 1971.

O'KEEFE, J.; NADEL, L. The hippocampus as a cognitive map. [s.I.] Oxford: Clarendon Press, 1978a.

O'KEEFE, J.; NADEL, L. The hippocampus as a cognitive map. [s.I.] Clarendon Press Oxford, $1978 \mathrm{~b}$. 
O'KEEFE, J.; SPEAKMAN, A. Single unit activity in the rat hippocampus during a spatial memory task. Experimental Brain Research, v. 68, n. 1, p. 1-27, 1987.

OSTER, G. F.; WILSON, E. 0. Caste and ecology in the social insects. Monographs in Population Biology, v. 12, p. 1-352, 1978.

PERNA, A. et al. Individual rules for trail pattern formation in Argentine ants (linepithema humile).

PLoS Computational Biology, v. 8, n. 7, 2012.

PERRY, C. J.; BARRON, A. B.; CHITTKA, L. The frontiers of insect cognition. Current Opinion in Behavioral Sciences, v. 16, p. 111-118, 2017.

PINTER-WOLLMAN, N. et al. Harvester ants use interactions to regulate forager activation and availability. Animal Behaviour, v. 86, n. 1, p. 197-207, jul. 2013.

PLESS, E. et al. Interactions increase forager availability and activity in harvester ants. PLoS ONE, v. 10, n. 11, p. 1-18, 2015.

PRABHAKAR, B.; DEKTAR, K. N.; GORDON, D. M. The Regulation of Ant Colony Foraging Activity without Spatial Information. PLoS Computational Biology, v. 8, n. 8, 2012.

PRICE, R. I. et al. Symmetry breaking in mass-recruiting ants: extent of foraging biases depends on resource quality. Behavioral Ecology and Sociobiology, p. 1-8, 2016.

REID, C. R. et al. Information integration and multiattribute decision making in non-neuronal organisms. Animal Behaviour, v. 100, p. 44-50, 2015.

REID, C. R.; SUMPTER, D. J. T.; BEEKMAN, M. Optimisation in a natural system: Argentine ants solve the Towers of Hanoi. The Journal of experimental biology, v. 214, n. Pt 1, p. 50-58, 2011.

RIBEIRO, P. L. et al. Ants can learn to forage on one-way trails. PloS one, v. 4, n. 4, p. e5024, jan. 2009.

SALZEMANN, A. et al. Leaf-cutting ant Atta laevigata (Formicidae: Attini) marks its territory with colony-specific dufour gland secretion. Journal of Chemical Ecology, v. 18, n. 2, p. 183-196, 1992.

SASAKI, T. et al. Ant colonies outperform individuals when a sensory discrimination task is difficult but not when it is easy. Proceedings of the National Academy of Sciences, v. 110, n. 34, p. 1376913773, 2013.

SASAKI, T.; PRATT, S. C. The Psychology of Superorganisms: Collective Decision Making by Insect Societies. Annu. Rev. Entomol, v. 63, n. 1, p. 259-275, 2018.

SCHNELL, D. J. et al. Emergent Sensing of Complex Environments by Mobile Animal Groups. $\mathrm{n}$. February, p. 574-576, 2013.

SCHWARZ, S. et al. How Ants Use Vision When Homing Backward. Current Biology, v. 27, n. 3, p. 401-407, 2017.

SCOVILLE, W. B.; MILNER, B. LOSS OF RECENT MEMORY AFTER BILATERAL HIPPOCAMPAL LESIONS. Journal of Neurology, Neurosurgery \& Psychiatry, v. 20, n. 1, p. 11-21, 1 fev. 1957.

SEELEY, T. D. The wisdom of the hive: the social physiology of honey bee colonies. [s.I.] Harvard University Press, 2009.

SHERRY, D. F. et al. Are There Place Cells in the Avian Hippocampus? Brain, Behavior and Evolution, v. 90, n. 1, p. 73-80, 2017. 
SHETTLEWORTH, S. J. Cognition, evolution, and behavior. [s.I.] Oxford University Press, 2010.

SILVA, P. S. D. et al. Foraging in highly dynamic environments: Leaf-cutting ants adjust foraging trail networks to pioneer plant availability. Entomologia Experimentalis et Applicata, v. 147, n. 2, p. 110-119, 2013.

SMITH, C. R. et al. Genetic and genomic analyses of the division of labour in insect societies. Nature reviews. Genetics, v. 9, n. 10, p. 735-748, out. 2008.

SUMPTER, D. J. T. The principles of collective animal behaviour. Philosophical Transactions of the Royal Society B: Biological Sciences, v. 361, n. 1465, p. 5-22, 2006.

TABONE, M.; ERMENTROUT, B.; DOIRON, B. Balancing organization and flexibility in foraging dynamics. Journal of Theoretical Biology, v. 266, n. 3, p. 391-400, 2010.

THORNDYKE, P. W.; HAYES-ROTH, B. Differences in spatial knowledge acquired from maps and navigation. Cognitive Psychology, v. 14, n. 4, p. 560-589, 1982.

TINBERGEN, N. Über die Orientierung des Bienenwolfes (Philanthus triangulum Fabr.) - III. Die Bevorzugung Bestimmter Wegmarken. Zeitschrift Für Vergleichende Physiologie, v. 25, n. 3, p. 292-334, 1938.

TOFTS, C.; FRANKS, N. R. Doing the right thing: Ants, honeybees and naked mole-rats. Trends in ecology \& evolution, v. 7, n. 10, p. 346-349, out. 1992.

TURNER-EVANS, D. B.; JAYARAMAN, V. The insect central complex. Current Biology, v. 26, n. 11, p. R453-R457, 2016.

UDIANI, O.; PINTER-WOLLMAN, N.; KANG, Y. Identifying robustness in the regulation of collective foraging of ant colonies using an interaction-based model with backward bifurcation. Journal of Theoretical Biology, v. 367, p. 61-75, 2015.

VARGA, A. G. et al. Spatial Navigation and the Central Complex: Sensory Acquisition, Orientation, and Motor Control. Frontiers in Behavioral Neuroscience, v. 11, n. January, 2017.

VITTORI, K. et al. Path efficiency of ant foraging trails in an artificial network. Journal of Theoretical Biology, v. 239, n. 4, p. 507-515, 21 abr. 2006.

VON FRISCH, K.; LINDAUER, M. The "Language" and Orientation of the Honey Bee. Annual Review of Entomology, v. 1, n. 1, p. 45-58, jan. 1956.

VON THIENEN, W.; METZLER, D.; WITTE, V. Modeling shortest path selection of the ant Linepithema humile using psychophysical theory and realistic parameter values. Journal of Theoretical Biology, v. 372, p. 168-178, 2015.

WALD, A. Sequential tests of statistical hypotheses. The Annals of Mathematical Statistics, v. 16, $n$. 2, p. 117-186, 1945.

WASSERMAN, E. A.; MILLER, R. R. What'S Elementary About Associative Learning? Annual Review of Psychology, v. 48, n. 1, p. 573-607, 1997.

WEBER, N. A. The Fungus-Culturing Behavior of Ants. American Zoologist, v. 12, n. 3, p. 577-587, 1972.

WEHNER, R. et al. Bees navigate by using vectors and routes rather than maps.

Naturwissenschaften, v. 77, n. 10, p. 479-482, 1990. 
WEHNER, R. et al. Ant navigation: One-way routes rather than maps. Current Biology, v. 16, n. 1, p. 75-79, 2006.

WEHNER, R. Early ant trajectories: spatial behaviour before behaviourism. Journal of Comparative Physiology A: Neuroethology, Sensory, Neural, and Behavioral Physiology, v. 202, n. 4, p. 247266, 2016.

WEHNER RÜDIGER; SRINIVASAN, M. V. Path integration in insects. In: JEFFREY, K. K. (Ed.). The neurobiology of spatial behaviour. Oxford: Oxford University Press, 2003. p. 9-30.

WETTERER, J. et al. On- and Off-Trail Orientation in the Leaf-Cutting Ant, Atta cephalotes ( $L$.) (Hymenoptera). Journal of the Kansas Entomological Society, v. 65, n. 1, p. 96-98, 1992.

WETTERER, J. K.; SCHULTZ, T. R.; MEIER, R. Phylogeny of fungus-growing ants (Tribe Attini) based on mtDNA sequence and morphology. Molecular phylogenetics and evolution, v. 9, n. 1, p. 42-47, 1998.

WHEELER, W. The ant-colony as an organism. Journal of Morphology, v. 22, n. 2, p. 307-325, 1911.

WHITE, N. M.; MCDONALD, R. J. Multiple Parallel Memory Systems in the Brain of the Rat. Neurobiology of Learning and Memory, v. 77, n. 2, p. 125-184, 2002.

WILSON, E. O. Source and Possible Nature of the Odor Trail of Fire Ants. Science, v. 129, n. 3349, p. 643, 1959.

WILSON, E. O. Chemical communication among workers of the fire ant Solenopsis saevissima (Fr. Smith) 2. An information analysis of the odour trail. Animal Behaviour, v. 10, n. 1, p. 148-158, 1962a.

WILSON, E. O. Chemical Communication Among Workers Of The Fire Ant Solenopsis saevissima (Fr . Smith) 1. The Organization of Mass-foraging. Animal Behaviour, v. 10, n. 1, p. 134-147, 1962b.

WILSON, E. O. What is sociobiology? Society, v. 15, n. 6, p. 10-14, set. 1978.

WILSON, E. O. Caste and Division of Labor in Leaf-Cutter Ants ( Hymenoptera: Formicidae: Atta ) II. The Ergonomic Optimization of Leaf Cutting. Behavioral Ecology and Sociobiology, v. 7, n. 2, p. 157-165, 1980.

WILSON, E. O. Caste and division of labor in leaf-cutter ants (Hymenoptera: Formicidae: Atta) III. Ergonomic resiliency in foraging by $A$. cephalotes. Behavioral Ecology and Sociobiology, v. 14, n. 1, p. 47-54, dez. 1983.

WITTLINGER, M. The Ant Odometer: Stepping on Stilts and Stumps. Science, v. 312, n. 5782, p. 1965-1967, 30 jun. 2006.

WYSTRACH, A. et al. Snapshots in ants? New interpretations of paradigmatic experiments. The Journal of experimental biology, v. 216, n. January, p. 1766-70, 2013.

WYSTRACH, A.; MANGAN, M.; WEBB, B. Optimal cue integration in ants. Proceedings. Biological sciences, v. 282, n. 1816, p. 20151484, 7 out. 2015.

XAVIER, G. F.; COSTA, V. C. I. Dentate gyrus and spatial behaviour. Progress in Neuro-

Psychopharmacology and Biological Psychiatry, v. 33, n. 5, p. 762-773, 2009.

YAGI, R. et al. Convergence of multimodal sensory pathways to the mushroom body calyx in Drosophila melanogaster. Scientific Reports, v. 6, n. April, p. 1-8, 2016. 
ZABZINA, N. et al. Symmetry Restoring Bifurcation in Collective Decision-Making. PLoS Computational Biology, v. 10, n. 12, 2014. 


\section{Anexo}

Página destacável para facilitar a leitura da seção de resultados

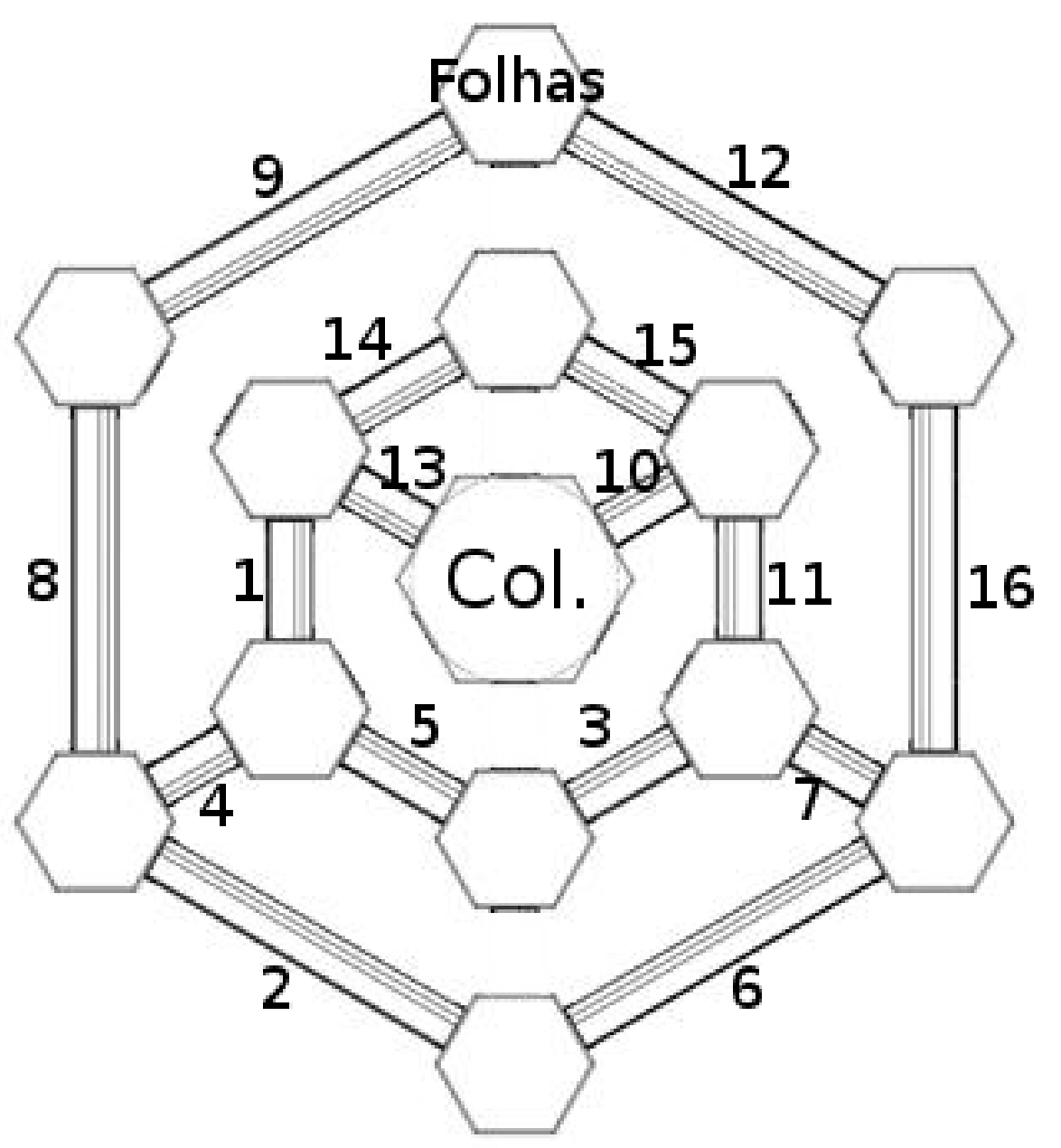

